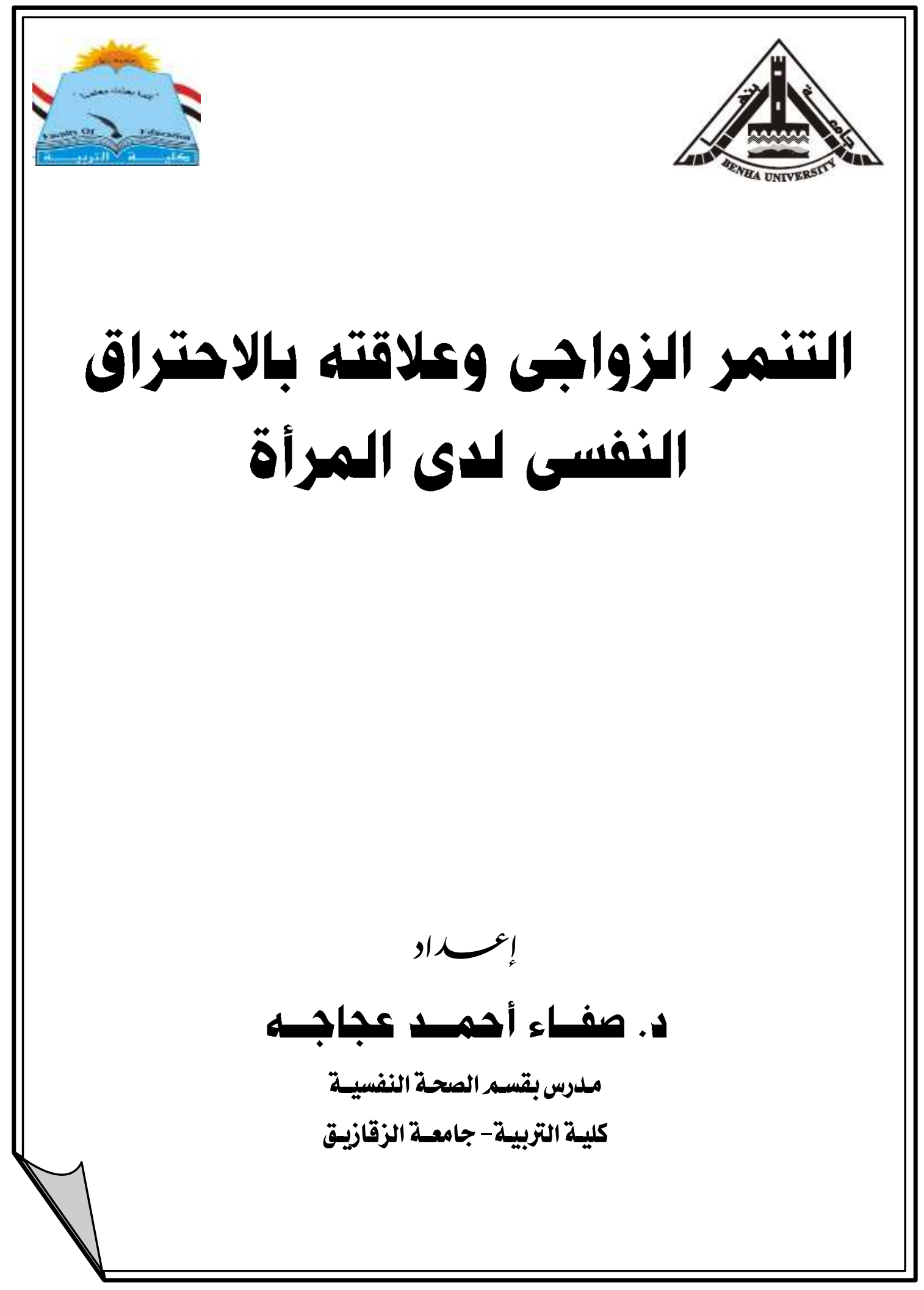




\section{التنمر الزواجى وعلاقته بالاحتراق النفسى لدى المرأة}

$$
\text { ! إع }
$$

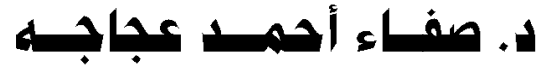

ملدرس بقسم الصحة النفسيـة

كلية التربية- جامعـة الزقازيق النفية

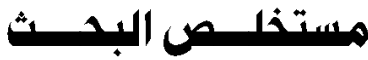

يهدف البحث الحالى إلى دراسـة العلاقة بين التتمر الزواجى والاحتراق النفسى لدى

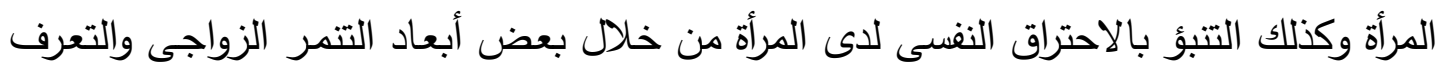

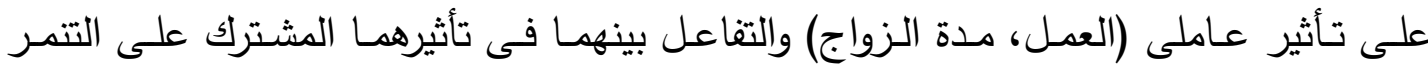
الزواجى والاحتراق النفسى لدى المرأة. والتعرف أيضًا على الديناميات النفسية لمرتفعى الاحتراق

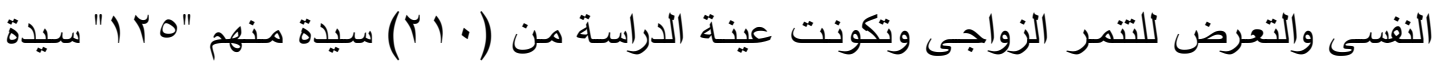

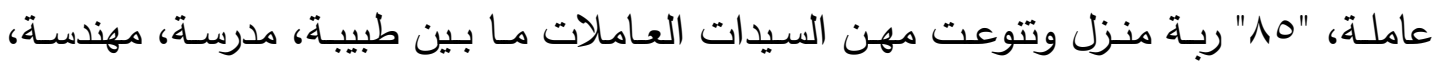

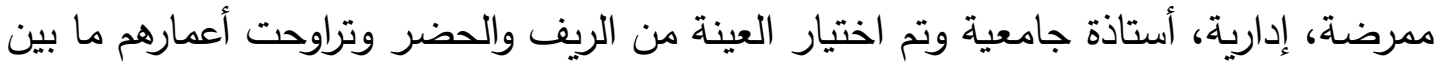

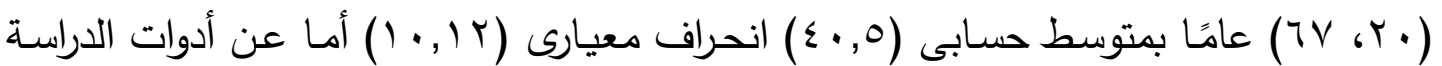

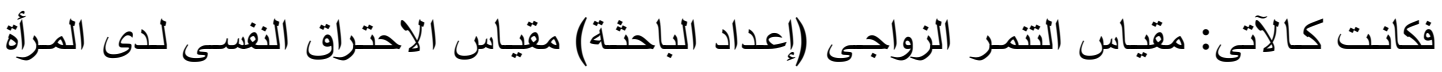

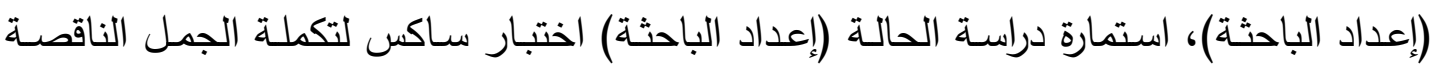

$$
\text { (اعداد جوزيف ساكس وترجمه أحمد سلامه . } 9 \text { ( ) ). }
$$

وأما عن نتائج الاراسة فكانت كالآتى:

وجود علاقة ارتباطية ذات دلالة إحصائية بين التتمر الزواجى والاحتراق النفسى لدى المرأة.

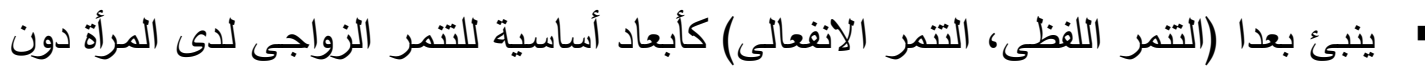

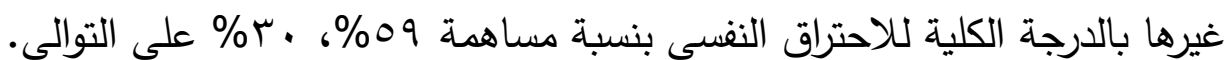
لا توجد فروق ذات دلالة إحصائية بين (السيدات العاملات، غير العاملات "ربات البيوت") فى الدرجة الكلية للتمر الزواجى.

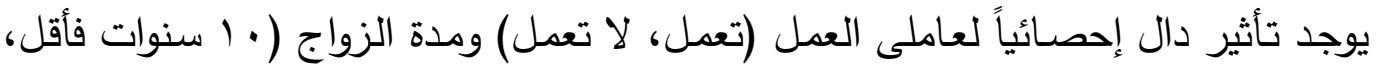

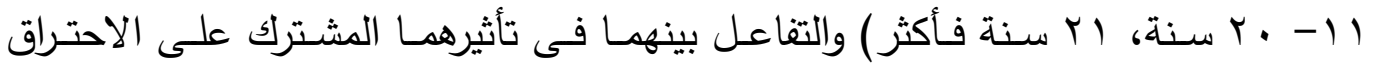
النفسى لاى المرأة. • من أسباب التتمر الزواجى الذى تتعرض له المرأة هو ضعف الثقة بالنفس وضعف التوكيد على حقوقها وذلك طبقًا للدراسة الكلينكية. الكلمات المفتاحية: التتمر الزواجى، الاحتراق النفسى. 


\section{Abstract:}

The current research (study) aims to investigate the relationship between Marital Bullying and Psychological Burnout in women, as well as (likewise) to predict the Psychological Burnout of women throughout some dimensions of Marital Bullying. It also aims to identify the effect of two factors (work and marriage duration) and the interaction between them in their joint impact on Marital Bullying and Psychological Burnout in Women. This study also reveals the psychological dynamics of high Burnout and the psychological characteristics of those who have been subjected to Marital Bullying. The study sample (the sample of the study) consisted of (210) women, including (125) working women, (85) housewives. Women's jobs (professions) are varied from a doctor, a teacher, an engineer, a nurse, an administrative employee (administrator/Scribe), and a university professor. The sample was chosen (selected) from rural and urban areas, and their ages ranged between (20:67) years, with a mean (40.5) and a standard deviation (10.12).As for the study tools, they were as follows: Marital Bullying scale (prepared by the researcher), Case Study Form (prepared by the researcher), The Sacks Sentence Completion Test (SSCT).

\section{As for the results of the study, they were as follows:}

- There is a statistically significant correlation between Marital Bullying and Psychological Burnout in women.

- Two dimensions of marital bullying, verbal bullying and emotional bullying, as the main dimensions of marital bullying in women, only predict the total degree of psychological burn with a contribution of $59 \%$ and $30 \%$, respectively.

- There are no statistically significant differences between (working women and non-working women (housewives) in the total (overall) degree of marital bullying.

- There is a statistically significant effect of the two factors, the work (working, not working) and the marriage duration (10 years or less, 11-20 years or more), and the interaction between them in their joint effect on women's psychological burnout.

- According to the results of the clinical study, among the causes (the etiology) of Marital Bullying that women are exposed to, is the lack of self-confidence (poor self -confidence) and the A defect in assertiveness when it comes to claiming rights.

Keywords: Marital Bullying, Psychological Burnout. 
الزواج هو العلاقة الثرعية المباحة بين المرآة، والرجل داخل الأسرة، والمجتمع والتى قد

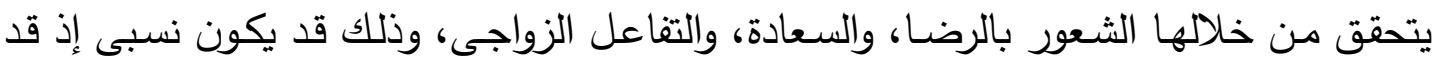
تتعرض تلك العلاقة إلى بعض المشكلات النفسية الاجتماعية التى قد تؤدى إلى عدم الرضا

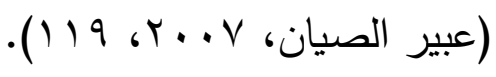

ومن المشكلات النفسية الاجتماعية التى تتؤثر على مجرى الحياة بين الزوجين وقد تصل بأحدهما إلى الاجهاد النفسى ومن ثم الاحتراق النفسى مشكلة التتمر الزواجى. والتتمر

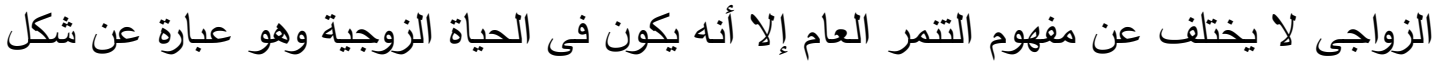

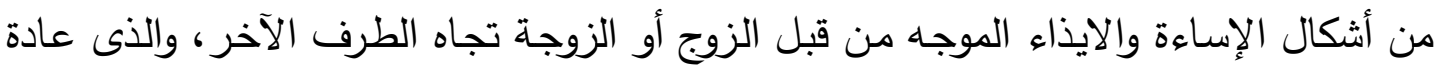
ما يكون هو الحلقة الأضعف فى العلاقة. وقد أشار "ديكرسون" (Dickerson, 2005) إلى وجود حالات تنمر بين الأزواج حيث

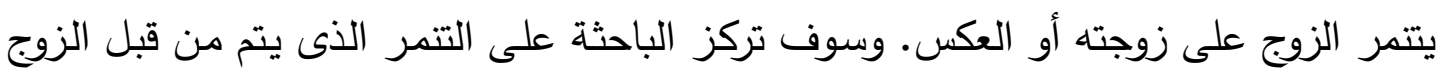

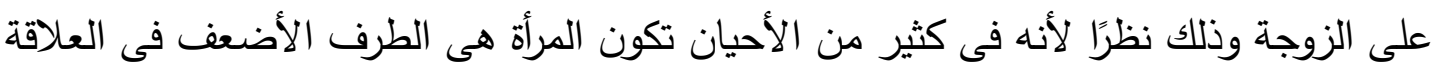

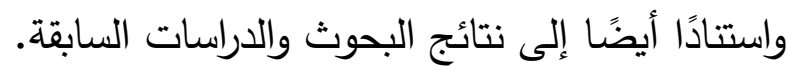

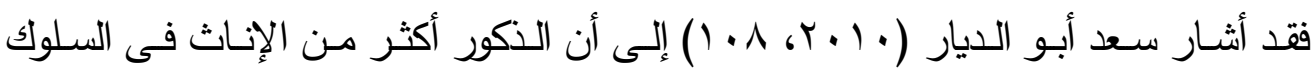

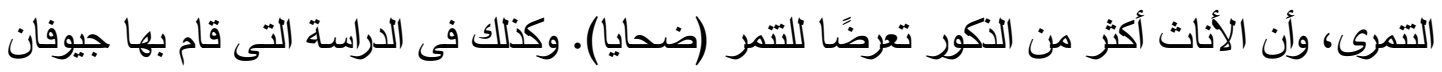

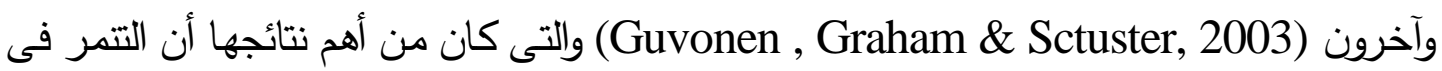

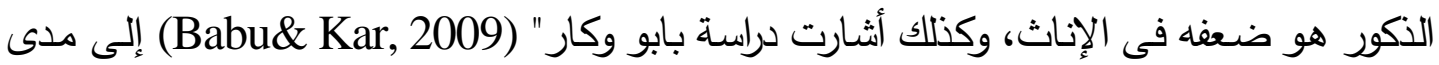

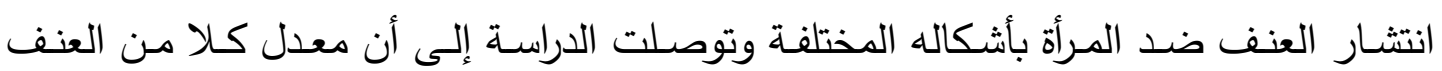

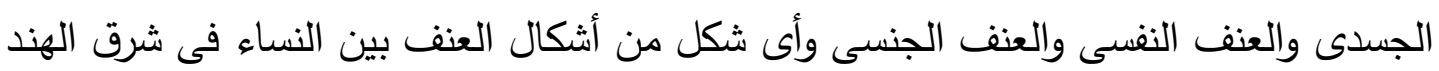

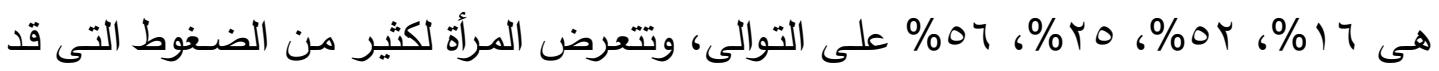

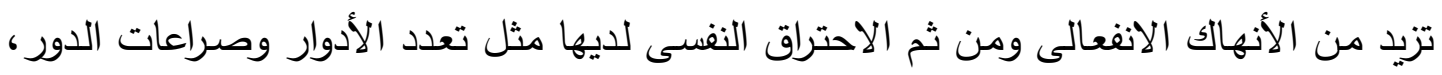

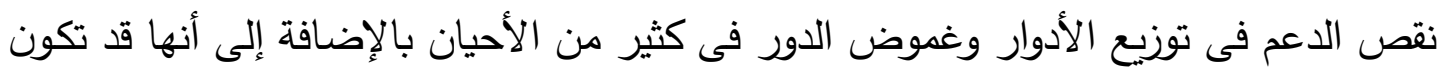

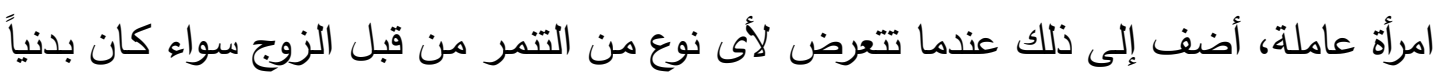

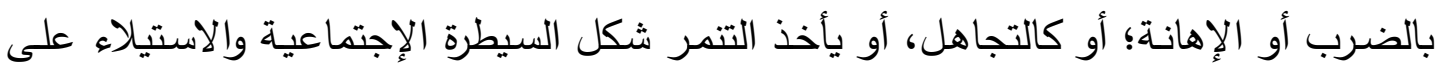

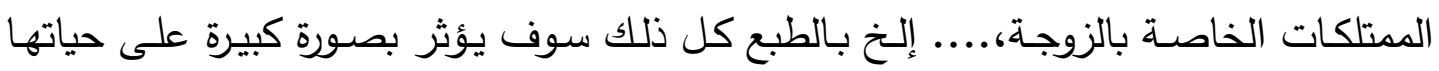
النفسية والبدنية وعطائها وانجازها واقبالها على الحياة بصفة عامة. 
وربما هذا مادفع الباحثة إلى اجراء هذا البحث لمعرفة العلاقة الارتباطية بين التتمر الزواجى بأبعاده المختلفة والاحتراق النفسى لاى المرأة التى تعتبر هى أساس الجى المجتمع.

\section{مشكلـــة البدــث}

تتعرض المرأة لكثير من الضغوط التى قد تزيد من الانهاك الإنفعالى ومن ثم الأحتراق

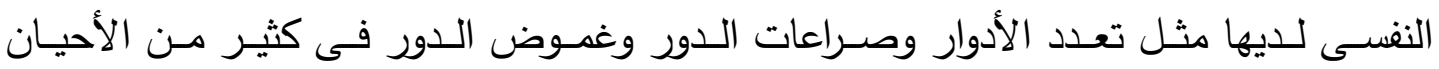

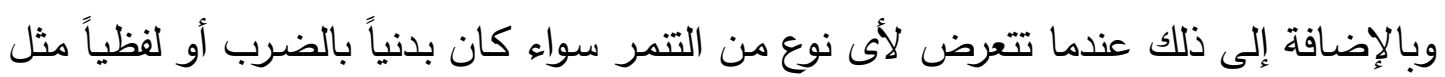

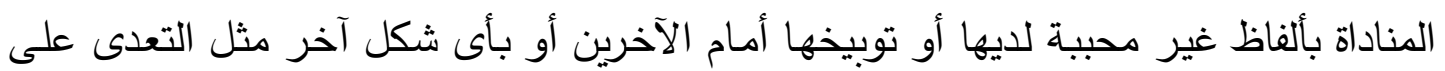

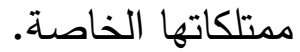

وقد أثارت العديد من الدراسات إلى تفش ظاهرة العنف ضد المرأة (مركز مساواة المرأة،

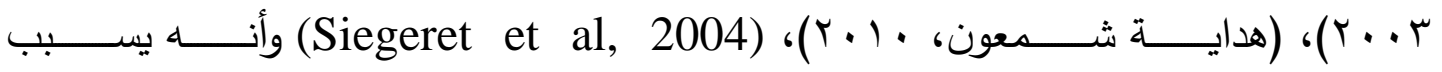

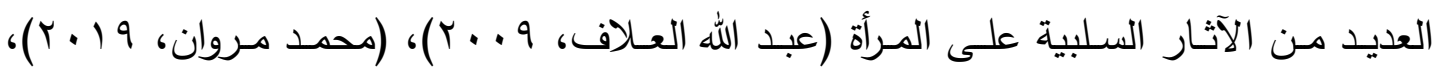
.(Melinda \& Jeanne, 2019)

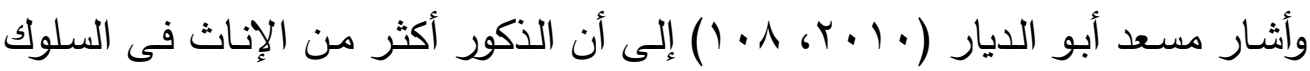
التتمرى. وقد قامت الباحثة بعمل دراسة استطلاعية على عدد كبير من السيدات من خلال اختلاطها بهم فى واقع الحياة توصلت من خلالها إلى تعرض عدد كدئ كبير منهم إلى الاحتراق النفسى بدرجات متفاوتة وكذلك إلى معانـاة الكثير منهم من التتمر الزواجى بمختلف صوره

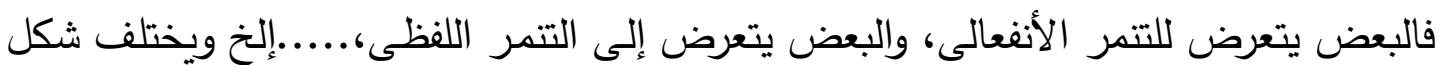
الاستجابة من سيدة إلى أخرى.

\section{وعلى ذلك يمكن تحديد تساؤلات البحث فيما يلى:}

1- هل توجد علاقة ارتباطية بين درجات التتمر الزواجى ودرجات الاحتراق النفسى

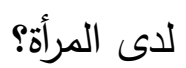

ץ- هل تتبئ بعض أبعاد التتمر الزواجى دون غيرها بالاحتراق النفسى لاى المرأة؟

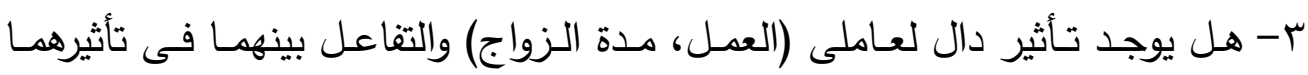

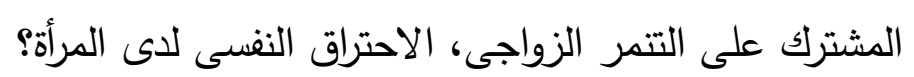

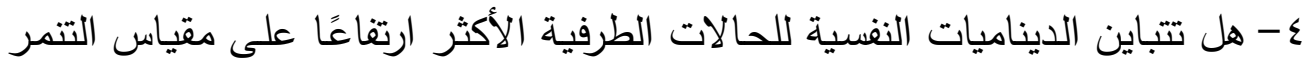

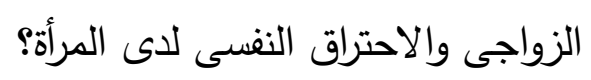


يستمد البحث أهميته من أهمية المتغيرات التى يتناولها ويمكن توضيحها فيما يلى: × دراسة العلاقة بين التتمر الزواجى الذى تتعرض له المرأة وعلاقته بالاحتراق النفسى لديها

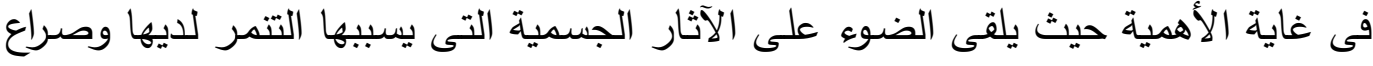

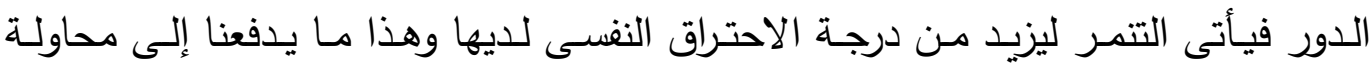

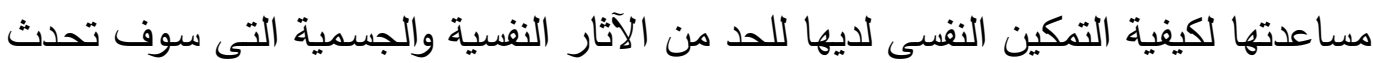
لها وكيفية مواجهة التتمر بدرجة عالية من الذكاء للوصول إلى حالة التوازن النفسى.

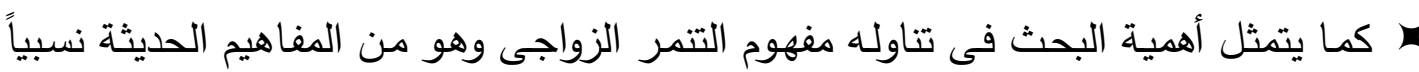
التى تحتاج إلى الدراسة والتحليل. (ب كما يستمد البحث أهيته من أهمية الثريحة التى يتتاولها ألا وهى المرأة فالمرأة هى نصف

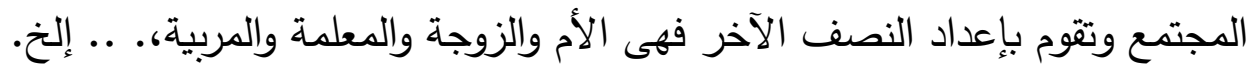

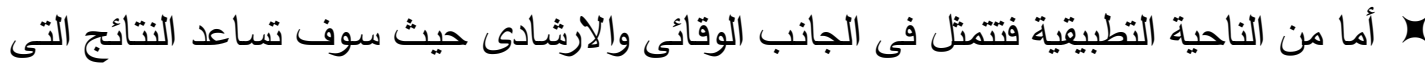

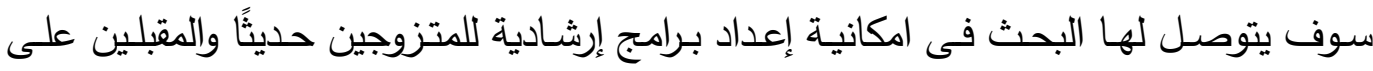
الزواج للتقليل من الاحتراق النفسى لديهم، تتمية مهارات المواجهة الإيجابية لمشكلة التتمر .

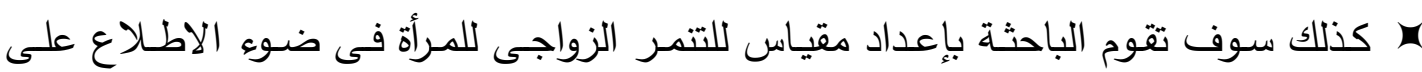

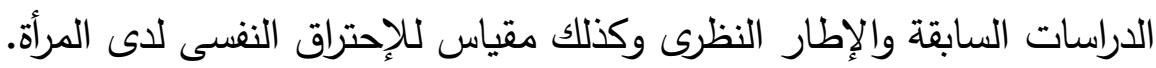

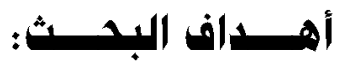 \\ يهاف هذا البحث إلى:}

جاساسة العلاقة بين التتمر الزواجى والاحتراق النفسى لدى المرأة.

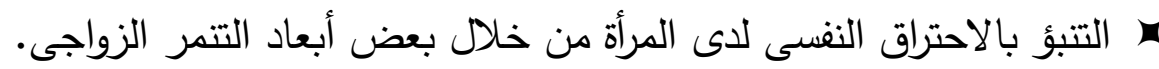

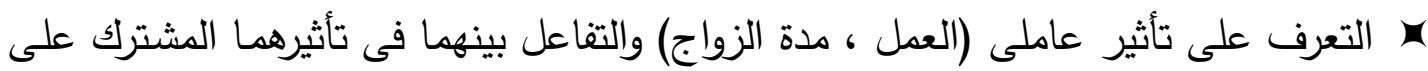
التتمر الزواجى والاحتراق النفسى لاى المرأة. (التعرف على الديناميات النفسية لمرتفعى الاحتراق النفسى والتعرض للتنمر الزواجى.

\section{مصطادات البدث الإجرائية:}

التنهر الزواجى : Marital Bullying:

التنمر الزواجى لا يختلف عن مفهوم التتمر العام إلا أنه يكون فى العلاقات الزواجية

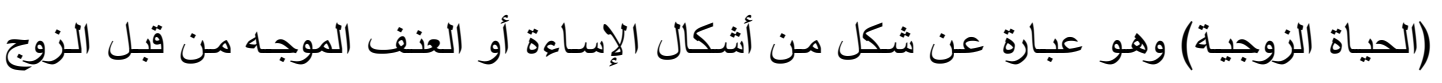


أو الزوجـة تجاه الطرف الآخر والذى يكون هو الطرف الأضعف فـى العلاقة ويحدث ذلك بصورة متكررة ومتعدة مما يسبب الكثير من الآثار النفسية والبدنية والاجتماعية التى تؤدى إلى الى الى

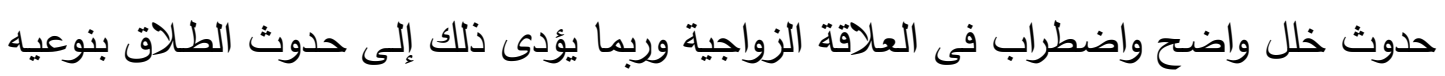
( الصامت، العادى) وسوء التوافق بصفة عامة.

والتتمر الذى تركز عليه الباحثة فى هذا البحث هو التتمر الزواجى للمرأة الذى يتم من

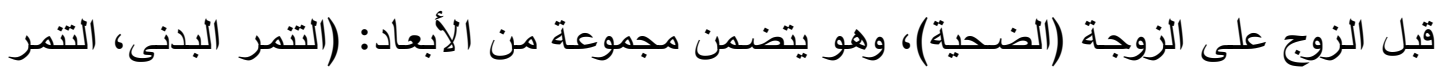

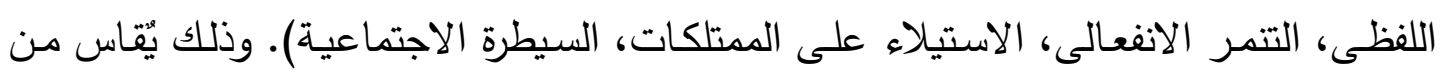

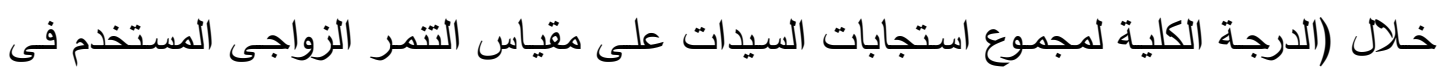

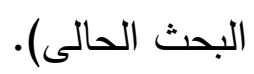

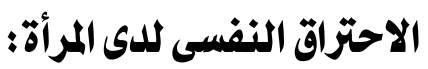

تُعرفه الباحثة إجرائياً بأنه درجة الفرد التى يحصل عليها فى مقياس الاحتراق النفسى التهى

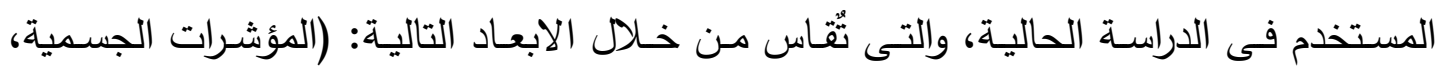
والمؤشرات السلوكية، والمؤشرات العاطفية).

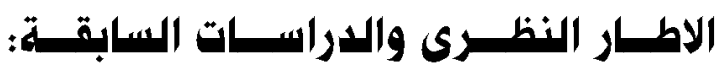

يعد التتمر من المشكلات النفسية الاجتماعية التى تلاقى اليوم اهتمامًا متزايدًا من قبل

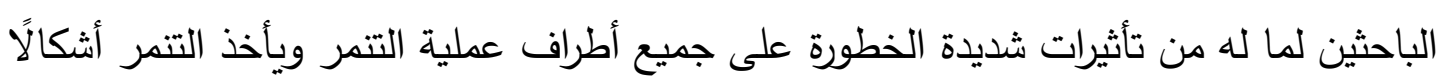

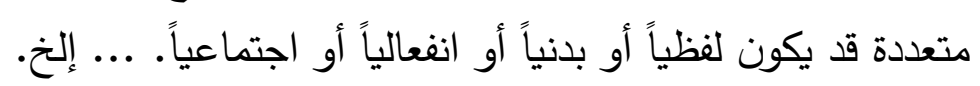

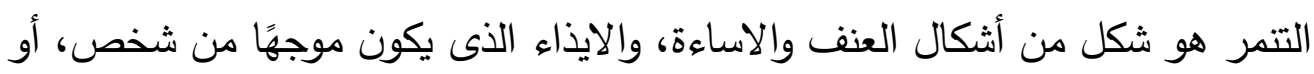

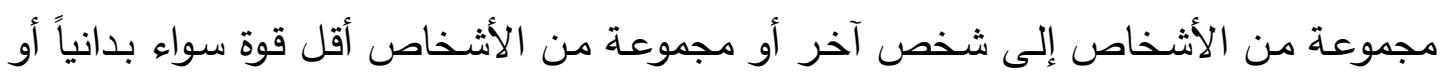
نفياً (Susanna et al , 2011).

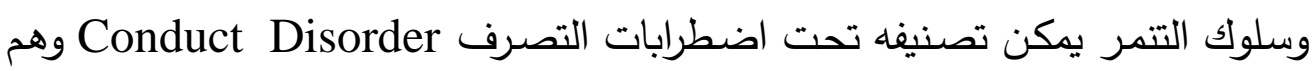

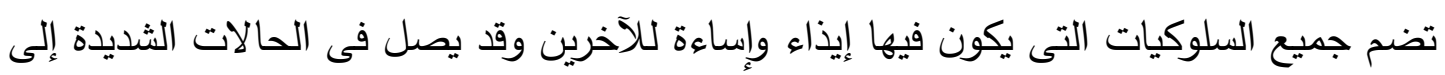

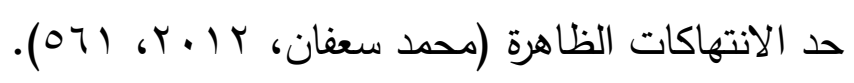

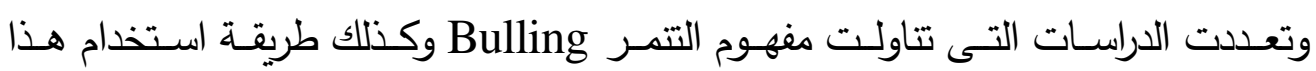

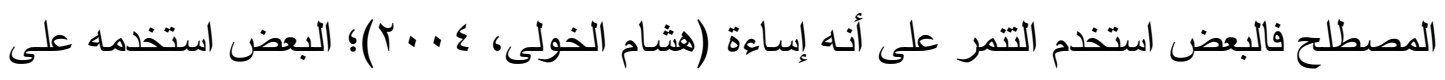

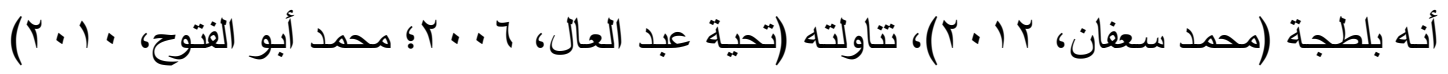

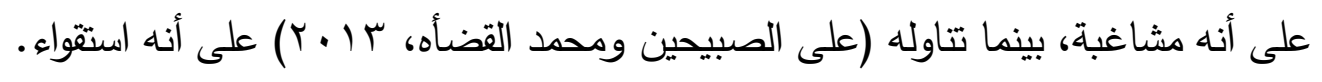


وأيا كانت الزاوية التى تتاولها العلماء فى استخدام المفهوم فإنه يمكن التوصل إلى أن

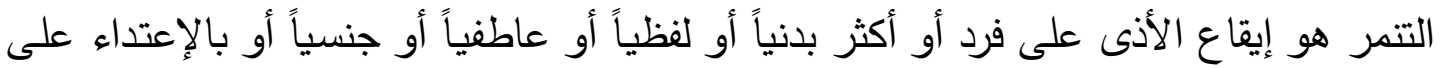
ممتلكاته الخاصة بقصد إثارة الخوف والضيق وإيذاء الضحية ويتم ذلك بصورة متكررة عبر فترة من الزمن وعامة يكون هناك عدم توازن فى القوى بين المتتمر والضحية وبالطبع يؤدى ذلك إلى

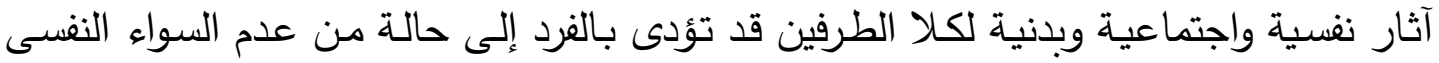

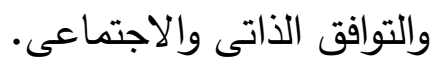
أما عن مفهوم التتمر الزواجى فهو لا يختلف عن مفهوم التتمر العام إلا أنه قد يكون

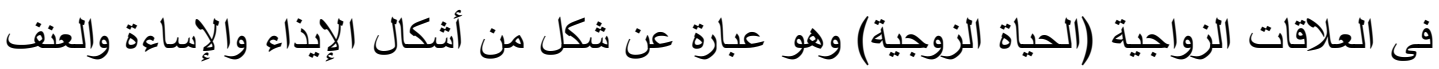

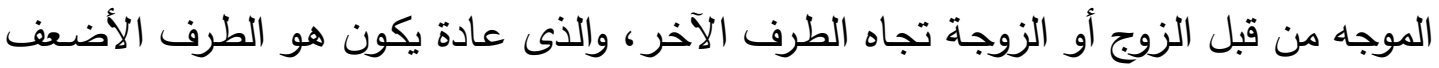
فى العلاقة ويحدث ذلك بصورة متكررة ومتعدة مما يسبب الكثير من الآثار النفسية والبدنية والاجتماعية التى تؤدى إلى حدوث خلل واضح واضطراب فى العلاقة الزواجية وربما يؤدى ذلك الك

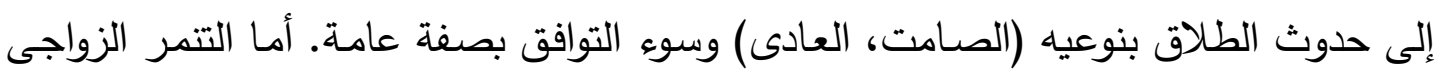

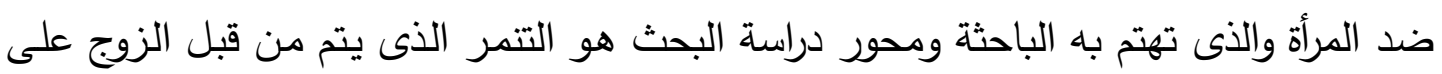
زوجته بإعتبارها الطرف الأضعف فى العلاقة فى كثير من الأحيان.

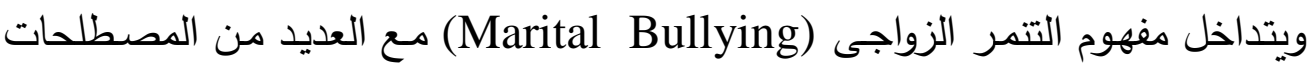

مثل: العنف الزواجى Marital Violence، العدوان الزواجى Marital Aggression،

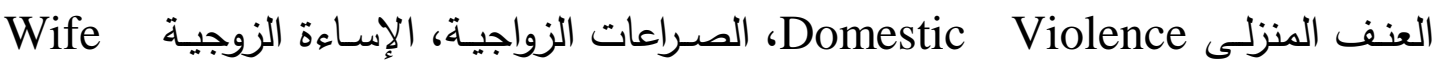
Abuse ونظرًا لحداثة مصطلح التمر الزواجى Marital Bulling وعدم توصل الباحثة إلى دراسة

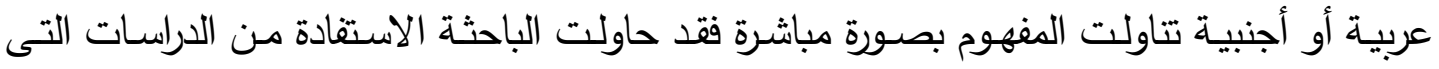

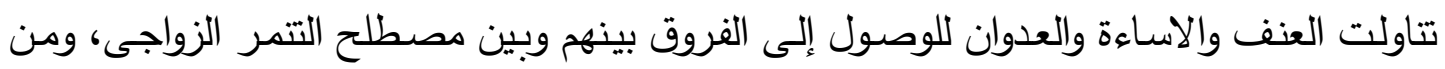

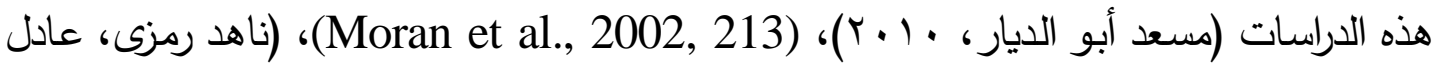

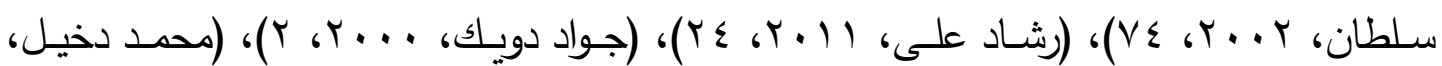

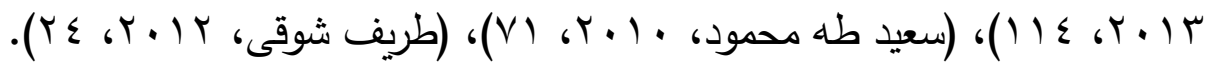

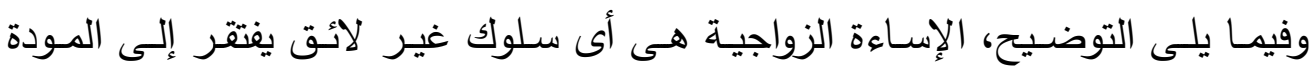

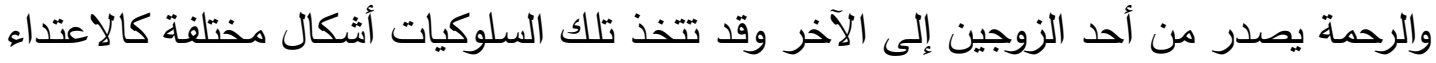


اللفظى، عدم الانفاق والهجرة،. .. إلخ، أى أنها التعرض لسوء المعاملة وحدوث الضرر، الإيذاء

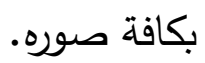

العنـف الزواجـى هو كل تصـرف يؤدى إلى إلــاق الأذى من أحـد الزوجين للآخر

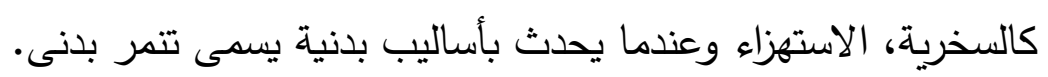

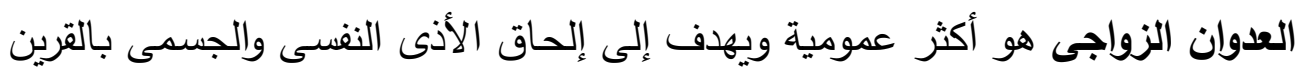
(شريك الحياة) وهو غير متكرر .

الصراعات الزواجية هى عرضية وبدون قصد ولا تشكل مشكلة خطيرة ولايسعى فيها أحد الزوجين إلى السيطرة أو الهيمنة. التنمر الزواجى أما التمر فهو أشد خطورة وهو نمط من العدوان الثديد ويهدف إلى الى إلحاق الأذى المتعدد من قبل أحد الزوجين بالآخر وكذلك يوجد فرق فى القوة بين المتنمر والضحية يسعى فيها المتنمر للسيطرة وفرض القوة، ويتجلى التتمر الزواجى عن طريق عدة علامات وهى اللوم المستمر ، الانتقادات الدائمة، الثخصية النرجسية، المزاجية المتقلبة، اختلاق المشاكل، الغيرة المرضية (Melinda \& Jeanne, 2019). وفى البحث الحالى حيث أن المقصود التتمر الزواجى الذى يتم من الزوج للزوجة بذلك

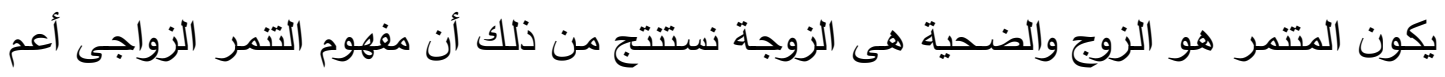

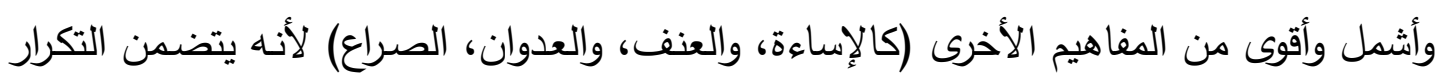
والقصد والتعدد ويشترط تفاوت القوى بين الطرفين بمعنى أن (الإساءة، العنف، العدوان) يعتبر تتمر ولكن بدرجات متفاوتة وإذا أضيف إليها العمد، القصد، التكرار. ويمكن توضيح عناصر عملية التنمر الزواجى كالتالى:

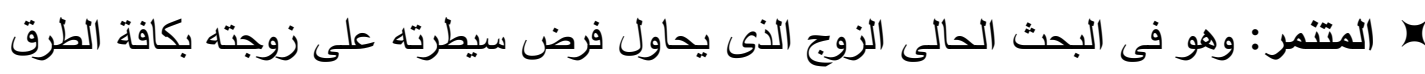
والوسائل. × الضحية: وهى الزوجة التى تتعرض للاعتداء وسلب الممتلكات وفرض السيطرة.

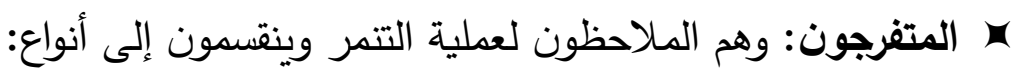

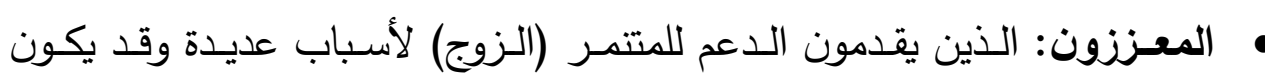

$$
\text { أصدقاء أو أهل الزوج مثلًا. }
$$


المدافعون (الحراس): وهم الذين يتعاطفون مع الضحية (الزوجة) ويقدمون لها

العون وقد يكون أهل الزوج أو الأصدقاء الحميمة المقربة.

• الخارجون (المحايدون): الذين لا يتحازون لأى من الطرفين.

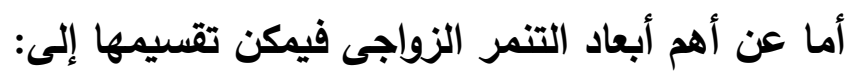

$$
\begin{aligned}
& \text { 1- تتمر بدنى } \\
& \text { r- تتمر لفظى }
\end{aligned}
$$

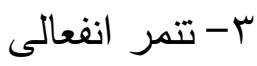

$$
\begin{aligned}
& \text { ع - الاستيلاء على الممتلكات } \\
& \text { 0- السيطرة الاجتماعية }
\end{aligned}
$$

أما عن أسباب التنمر ضد الزوجة فهى على سبيل المثال لا الحصر :

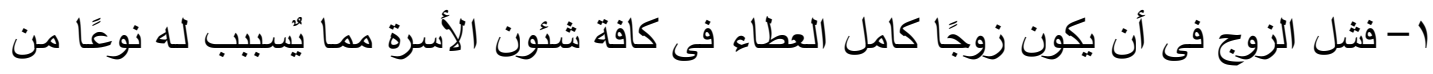

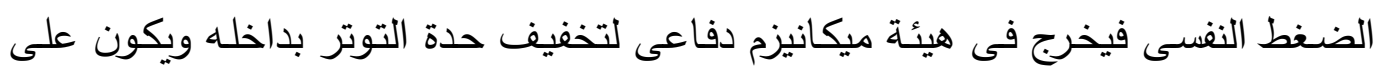

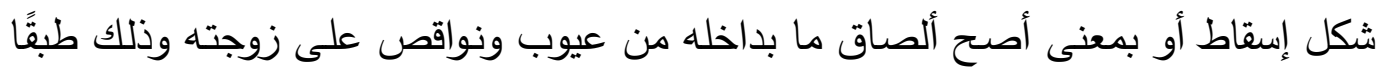
لنظرية التحليل النفسى، أى ان هناك دوافع لا شعورية تدفعه لذلك. لـأك.

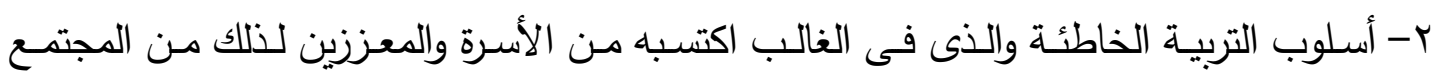

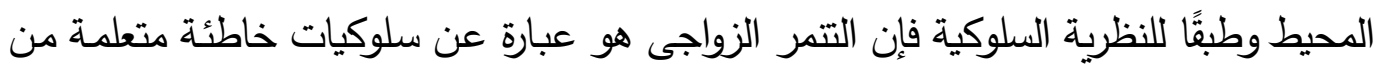

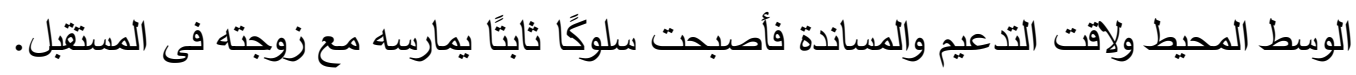

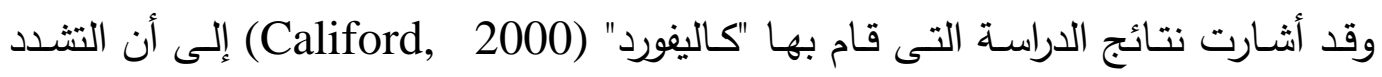

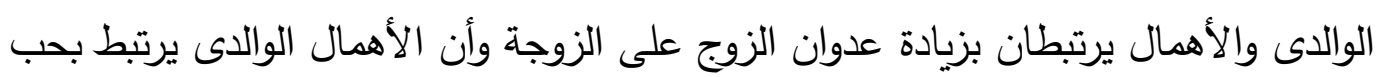

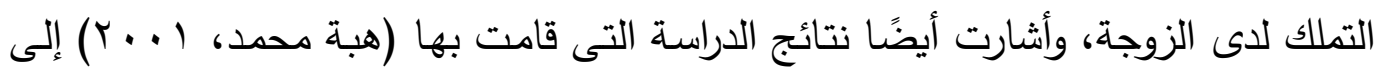

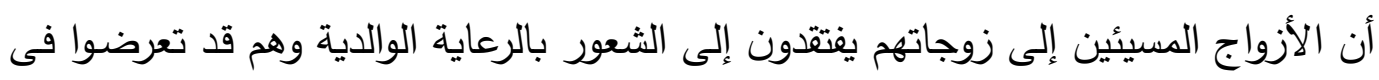

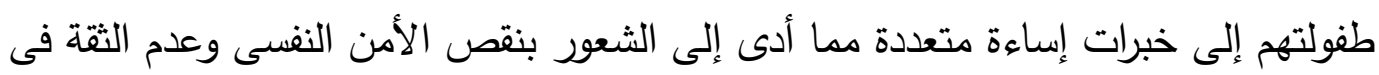
الذات مما أدى إلى تكرار خبرة الاساءة مع الزوجة والأبناء أيضًا.

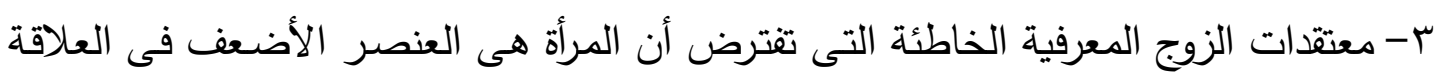

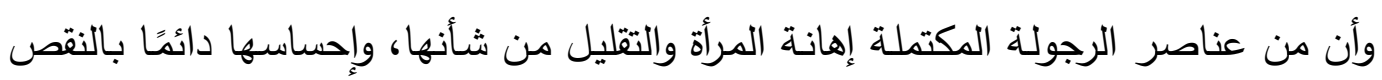
حتى لا ترتفع الأنا لديها أو تكون لها الأفضلية عنه طبقًا للنظرية المعرفية. 
ع - يمارس كثير من الأزواج التتمر ضد الزوجة كنوع من إثبات الذات لديه فغالبًا يفتقر هؤلاء

$$
\text { الأزواج إلى كيفية إدارة الذات بطريقة سوية. }
$$

ه- كذلك تلعب اضطرابات الثخصية لدى الزوج دورًا كبيرًا فى القيـام بعملية التتـر مثل اضطرابات الثخصية السادية، النرجسية، وغيرها.

فالشخص السادى يشعر باللذة من ضربه وتعذيبه للطرف الآخر لأن فى أعماقه رغبة فى السيطرة والهيمنة وإذلال الآخر (محمد سعفان، ب ا ـ r، 9)، والثخص النرجسى لديه من الزهو بنفسـه مـا يمنعـه من الاعتراف بأخطائه وإسقاط مـا بداخله على زوجته وأنها هـى المخطئة والمقصرة فى كل شئ حتى تظل الذات التى يرسمها لنفسه فى موضـع أقوى دائمًا فيجعل زوجته دائمًا فى وضع حيرة وغير قادرة على إرضاءه بل قد يوهمها بأنها هى التى لايها قصور فى فهمه والتعامل معه.

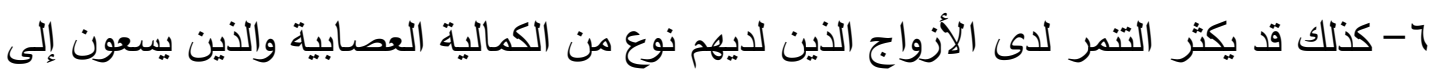
الكمال فى كل شئ ويعرفها ستوبير وأوتو (Stober \& Otto, 2006, 15) بأنها نمط شخصية تتميز بالسعى نحو الخلو من العيوب، ووضـع معايير أداء عالية للغاية جنبًا إلى جنب، مع الميل إلى انتقاد السلوك بشكل مفرط ، وطبقًا لنظريـة العلاج العقلانى الأنفعالى وكما أشار أليس فتعتبر الكمالية من الأفكار اللاعقلانية التى تسبب التعاسة لأصحابها. وكما يرى "ماستيجا ودوبريتا" (Macsinga \& Dobrita, 2010, 80) فإن الكمالية هى اتجاه الفرد نحو أداء كل شئ على أكمل وجه وبدون أدنى أخطاء أو تناقضات. وبـالطبع فإن الزوج الذى يتسم بـذلك فسوف لا يرضيه أى أداء مـن الزوجـة وسيمارس التتمر بصوره المختلفة سواء عن طريق السخرية أو التقليل من شأنها والاستهزاء بأدائها لأدوارها المختلفة مهما اجتهت مما سيؤثر بالسلب عليها وعلى مجرى الحياة الزوجية. V- قد يكون الدافع هو حب السيطرة وأن يكون رقم واحد أمام الجميع، وقد يكون تغطية للشعور بعدم الكفاءة والغيرة وانخفاض تقدير الذات وكذلك نقص الثعور بالأمن. 
^- طبقًا لنظريـة التعلم الاجتماعى فإن الزوج الذى يمارس سلوك التنمر فهو بالفعل قد تعمـه من البيئة المحيطة ونشأ فى أسر تمارس ذلك السلوك ضد زوجاتهم ويعتبرون ذلك جزء من ثقافتهم وتقاليدهم وبالتالى فما يفعله الآن ما هو إلا إعاده إنتاج الثقافة الأبويـة والمجتمعية للعنف الذى تعلمه. 9- هنالك أيضًا مجموعة من العوامل المرتبطـة بالضـية نفسها (الزوجـة) مثل نمط شخصية الزوجة وأسلوبها فى التعامل مع الأزمات، ضعف العلاقات الاجتماعية لديها، نقص الموارد الماليـة وعدم وجود مصـادر مسـاندة لديها سواء ماديـة أو معنويـة، ثقافـة القبول والخضـوع للزوج، التدنى فى مفهوم الذات، ضعف التوكيدية لديها. • 1- أشـارت دراسـة تم اجرائها عن العنف ضد المرأة فى المجتمع إلى أن أهم أسباب تعرض النساء للعنف هى كالتالى:

التمييز بين الرجل والمرأة بنسبة هب هـ

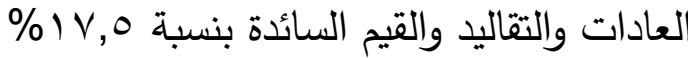
الضعف الجسمى للمرأة بنسبة 0 \%

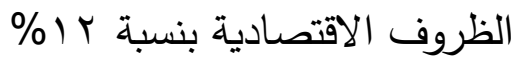

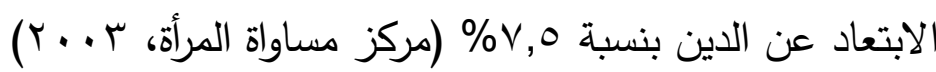
واتفتت معهم دراسة (هداية شععون، ( • ب) فى الجزء الخاص بالظروف الاقتصـادية،

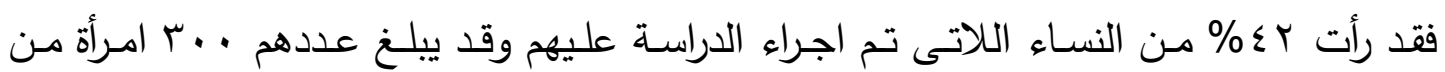
محافظة رفح فى أن من أهم أسباب العنف ضد المرأة فى الأسباب الاقتصادية كالفقر والديون والضغوط فى مجال العمل، وقد تم ترتيب الأسباب كالتالى من وجهة نظر النساء

$$
\text { \% \% }
$$

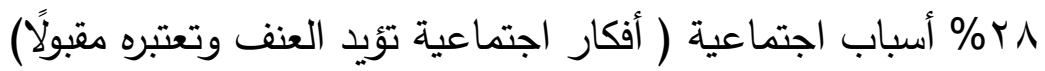

ع ( \% أسباب وعوامل شخصية (الأسباب النفسية، المرض النفسى والعقلى)

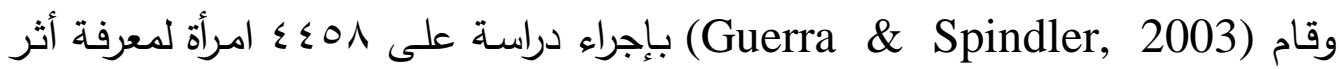

العنف المجتمعى وأثبتت الدراسة أن المعتقدات والمعايير السائدة عن العنف لها الأثر الأكبر فى لهى 


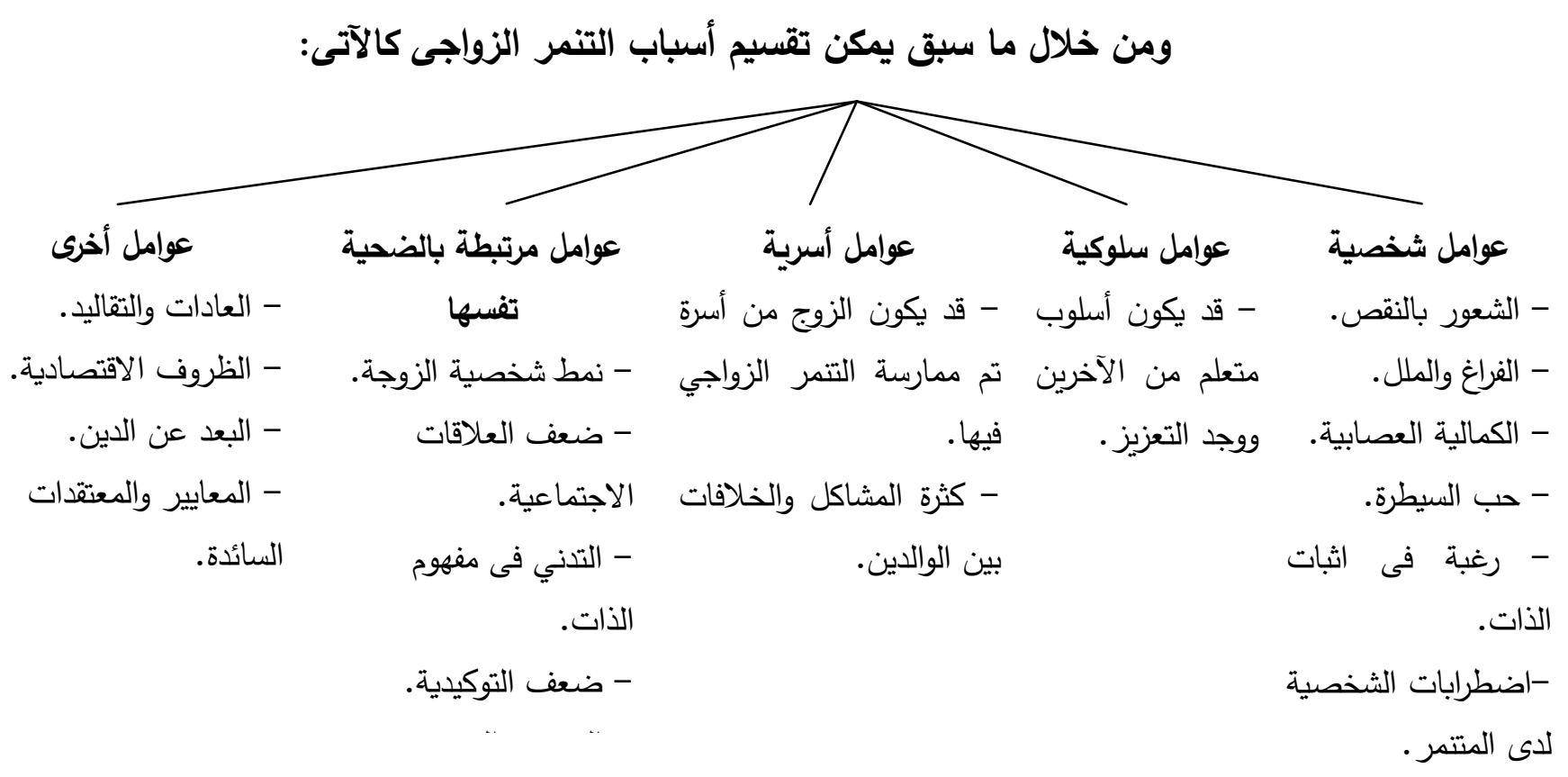

وبالطبع يوجد دورًا للزوجة فى مواجهة التنمر للحد من الاحتراق النفسى لديها ولكن قبل عرض ذلك سوف يتم عرض معنى الاحتراق ومراحله وأسبابه

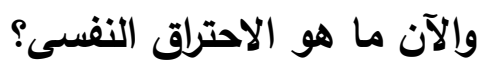

الاحتراق النفسى يعبر عن حالـة مـن الأنهاك أو الاستنزاف البدنى والانفعالى نتيجـة

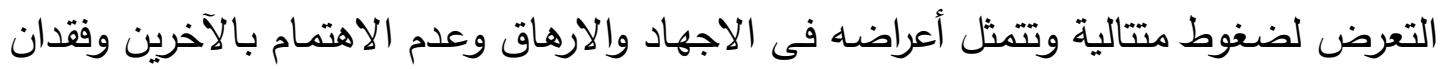

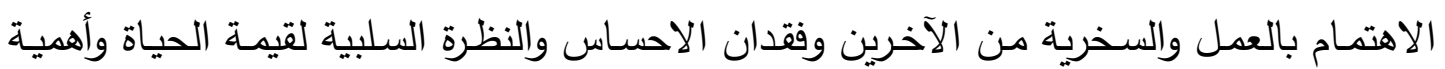
العلاقات الاجتماعية والسلبية فى مفهوم الذات (على العسكر ، . . . ب، هن ه ـ (1).

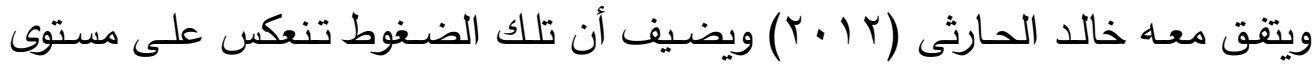

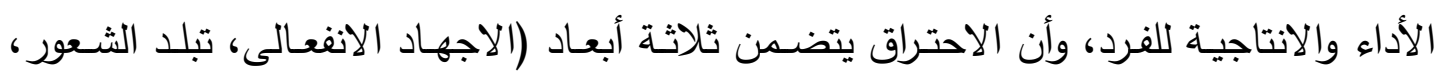
نقص الثعور بالأنجاز ).

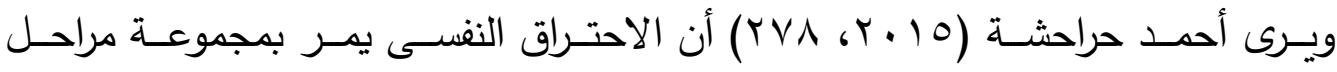

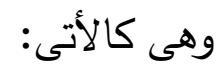

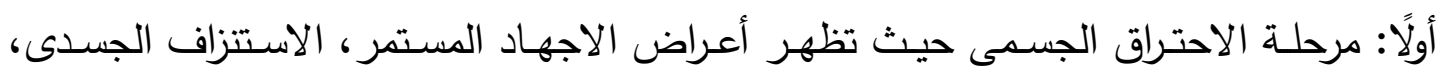
والقلق اليومى من الأمراض البسيطة.

ثانياً: مرحلة الاحتراق العقلى (الذهنى) تتمثل بضعف الأنس الانتباه ونقص التركيز والحماس، وترقب الوقت، انجاز الأعمال فى الدقائق الأخيرة. 


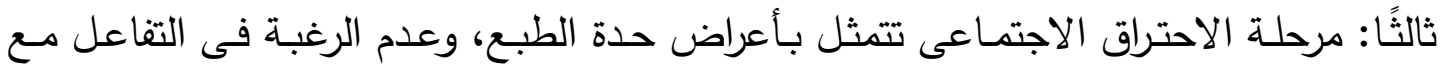

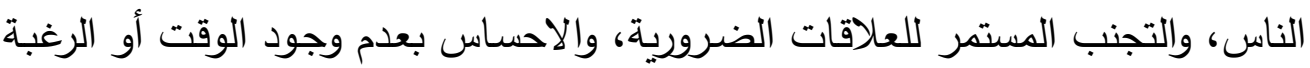

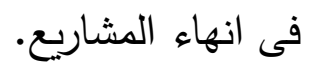

رابعًا: مرحلة الاحتراق النفسى والعاطفى وتتمثل بالقرار الواعى بترك المواعيد النهائية المقررة

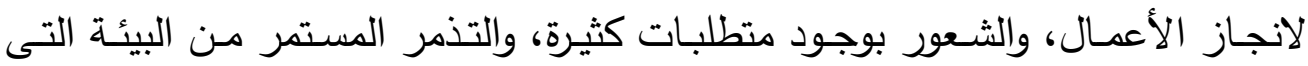
تسبب الاحتراق، والعزلة ورفض الاشتراك فى المهمات التى يتواجد فيها الناس.

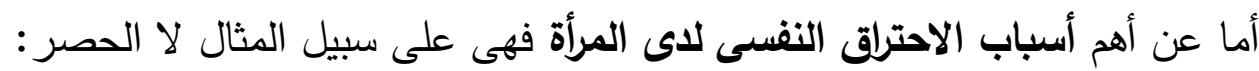

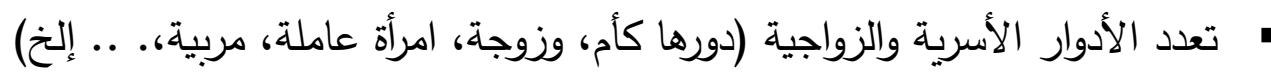

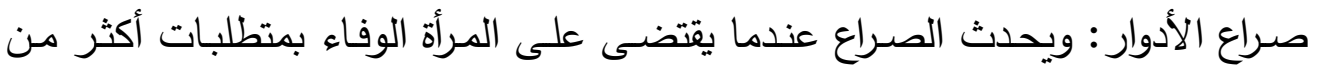

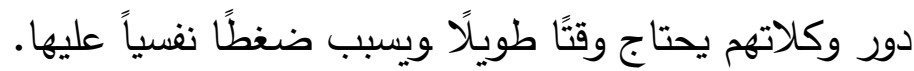
هوعية الأدوار التى تقوم بها حيث أن كل دور تقوم به له له متطلبات وجب علئ عليها القيام بها. غموض الدور عندما لا تعرف ما المطلوب منها.

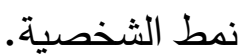

انخفاض معدل الصلاية النفسية لديها.

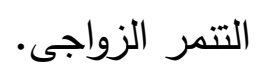
عدم تقدير الطرف الآخر (الزوج) لما تقوم به.

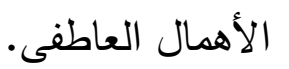
البرود العاطفى ونقص التعبير عن المشاعر. عدم فهم الزوج لسيكولوجية المرأة وطبيعة التغيرات النفسية والفسيووجية التى تطرأ عليها وتؤثر عليها. عدم مشاركته لها فى طموحها وأحلامها.

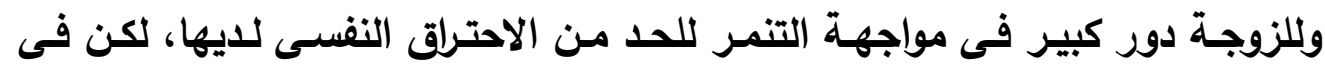
البداية يجب الوقوف على نقطتين هما: 1- السبب الحقيقى لتنمر الزوج. ب- نمط شخصيته.

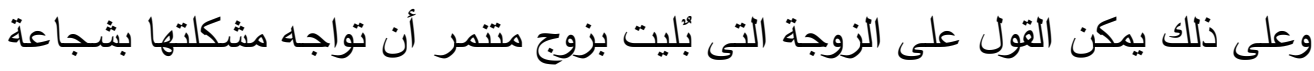

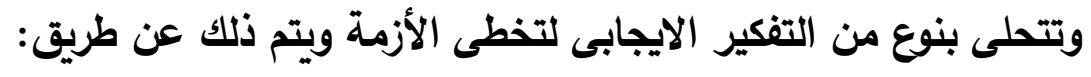

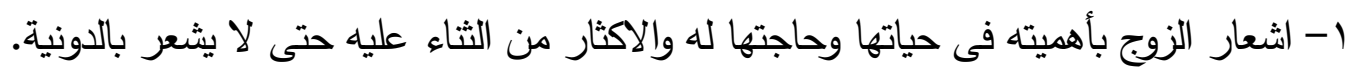


r- اشباع رغبات زوجها العاطفية واحتوائه نفياً وعاطفياً للقضاء على أسباب المشكلة لليه.

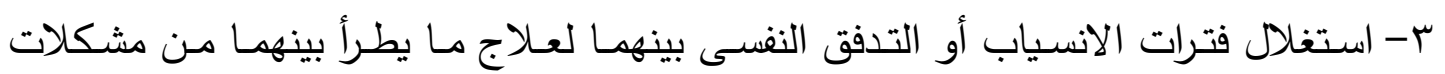
ومناقشتها بمنتهى الهدوء وهو من استراتيجيات علم النفس الآيجابى.

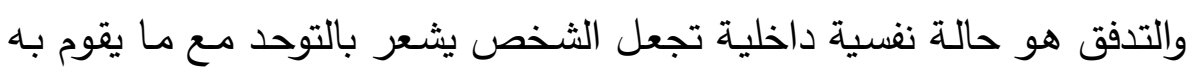

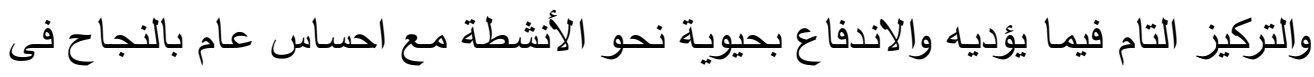

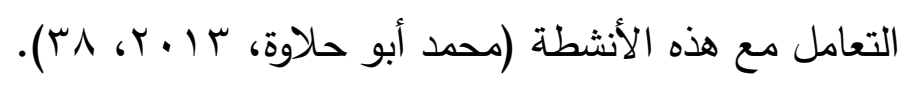

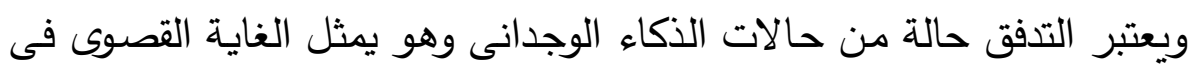
توظيف الانفعالات فى خدمة الأداء، وهو شعور راقى والعلاقة المميزة له هو الثعور

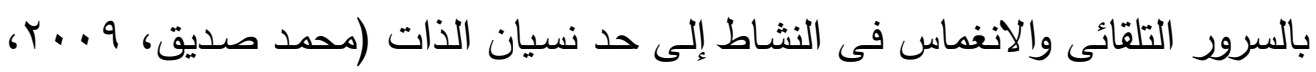

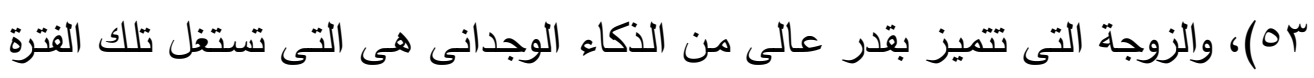

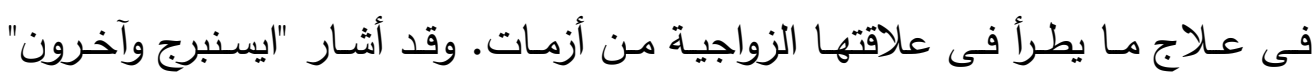
(Eisenberg \& Et al , 2005, 193) فيها الفرد بتحقيق أهدافه. ع - التجاهل بقدر الأمكان حتى ينطفئ هذا السلوك الغير مرغوب وهو فنية سلوكية يهدف الفرد منها إلى تعديل السلوك.

ه- اشرالك الزوج بقدر الأككان فى بعض المهام والأدوار المنزلية وإثعاره بالقوة.

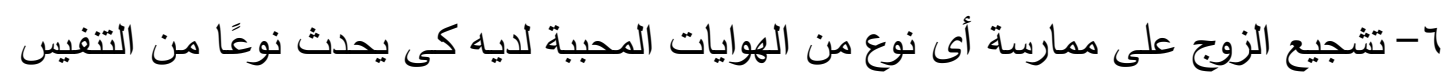
الانفعالى للشحنة السلبية الموجودة بداخله.

V - التدريب باستمرار على استخدام اليقظة العقلية فى مواجهة الأزمات الزوجية.

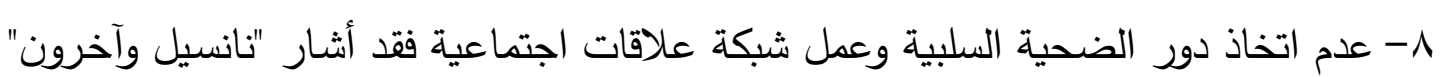
(Nansel \& Et al, 2001)

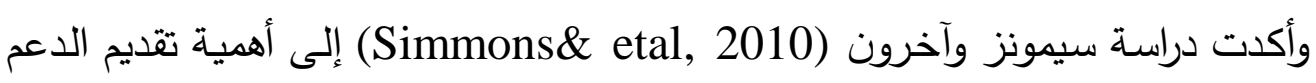
المناسب للمرأة التى تتعرض للعنف والتى تطلب المساعدة.

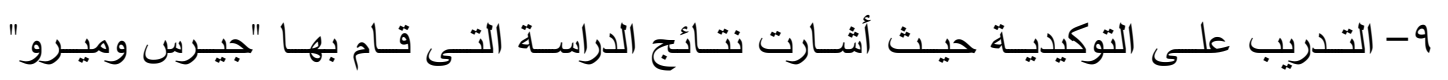
(Gracia\& Hero, 2010) تغاضت المرأة عن حقوقها بل ويلقى اللوم عليها، وفى الدراسة التى قام بإجرائها "أندرسون الأسي 
وآخرون" (Andersson ～\& Et al, 2010) والتى قام بإجرائها على السيدات اللاتى

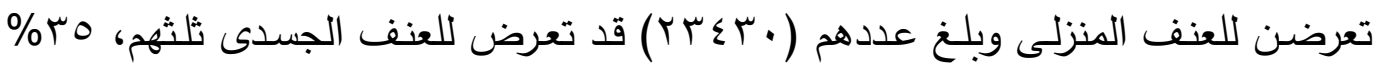

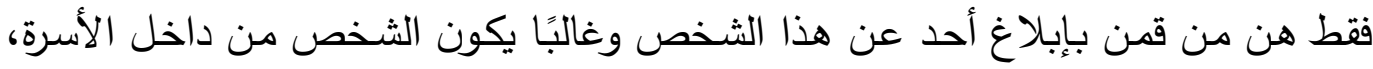
وأغلب السيدات لم تبلغ خوفًا من الطلاق أو تفاقم المشكلات أو فقدان فئان الأطفال.

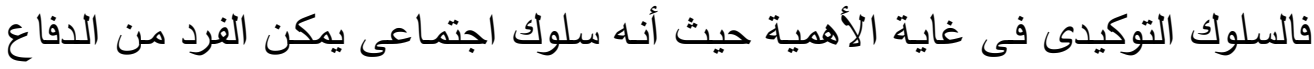
عن حقوقه الثخصية، والتعبير عن آرائه ومشاعره الايجابية والسلبية بصدق وتلقائية وفى نفس الوقت تكون لديه القدرة على رفض مطالب وضغوط الآخرين غير المنطقية، وعدم التردد فى الطلب والمبادأة فى اطـار اجتمـاعى مقبول وفق القيم الاجتماعيـة

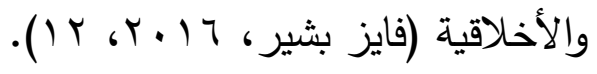

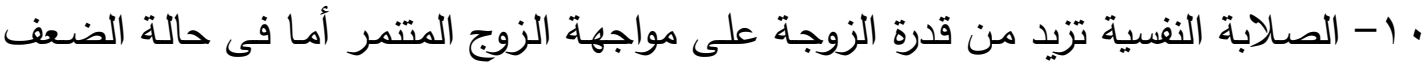

$$
\text { والاستسلام فسوف يتمادى الزوج فيما يفعله. }
$$

وترى "كوبازا" أن الصلابة النفسية مفيدة لمواجهة الضغوط والانهاك النفسى حيث تعدل

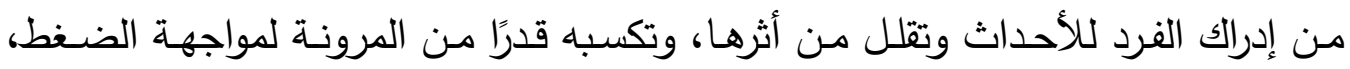

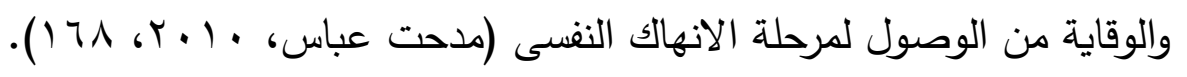

1 1- اتخاذ إجراءات تصحيحية بمعنى تغيير النمط السلبى اتجاه الذات والحياة بصفة عامة عن طريق تغيير العادات الخاطئة، التعاطف مع الذات والثفقة بها وعمل نوع من العزل التجريبى لما يقوله لما أو يفعله الزوج المتتمر حتى لا يؤثر بالسلب على نظرتها لذاتها، وقد توصل "هاوكر وبولتن" (Hawker \& Boulton, 2000) إلى أن ضحايا التنمر لديهم تقدير ذاتى منخفض. ومن المككن أيضًا محاولة جذب كل ما من شأنه رفع درجة السعادة والمناعة النفسية لاى المرأة من قبيل الأثياء والأشخاص الدحببة وتبنى أفكار أو مشروعات جديدة.

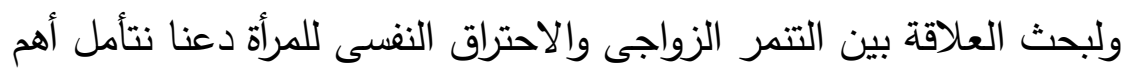

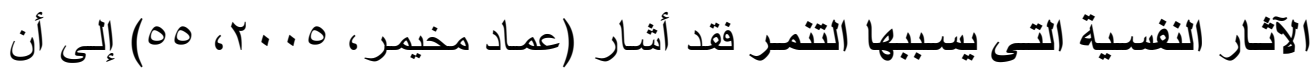

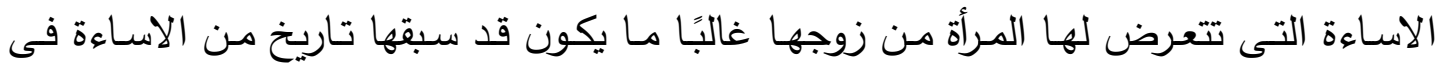
الطفولة مما يجعل المرأة محاصرة بالإساءة والاكتئاب والثعور بانخفاض قيمة الذات. 
وأكدت (ليلى مرح، 9 . . ب) إلى أن العنف يسبب الكثير من الأمراض النفسية، التفكيك

$$
\text { الأسرى، ازدياد الصراع فى الأسرة. }
$$

ويؤدى العنف الذى تتعرض له المرأة من الثريك إلى مجموعة من الآثار وهى كالتالى:

• مشاكل جسدية ونفسية وجنسية ومشاكل فى الصحة الإنجابية.

همكن أن يسفر العنف ضد المرأة عن عواقب مميتة، كالقتل والأنتحار .

كما تؤدى أشكال العنف إلى الإصـابة بالاكتئاب، اضطرابات الاجهاد اللاحقة، مشاكل

فى النوم، محن عاطفية.

هالاصابة بالصداع، وآلام فى الظهر والبطن، واضطرابات فى الألياف العضلية، والجهاز

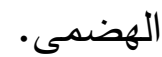

وقد تعانى النساء من العزلة، وعدم القدرة على العمل، وفقدان الأجر، ونقص المشاركة

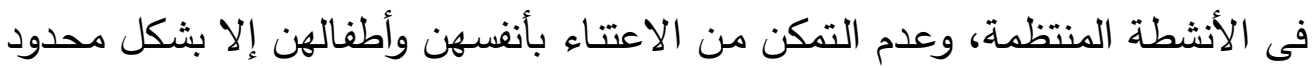
"رافنيت وسيونيلا" (Ravneet \& Suneela, 2008).

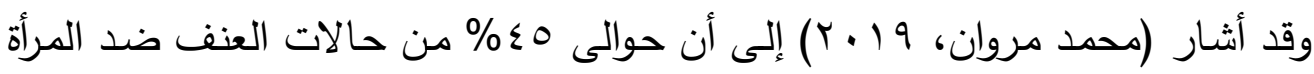

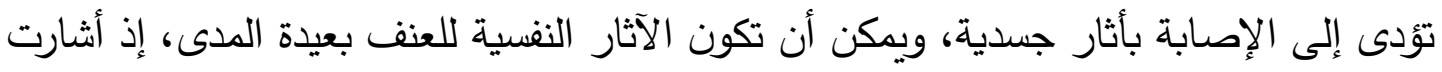

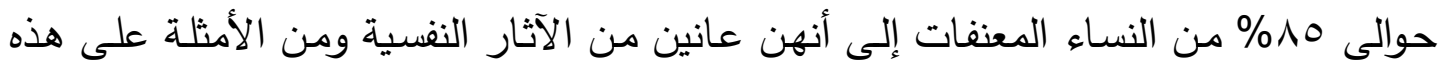

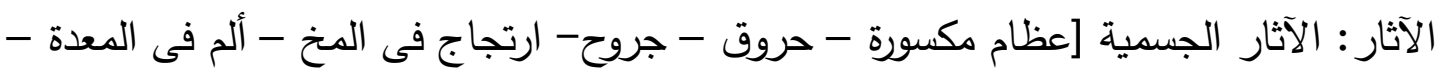

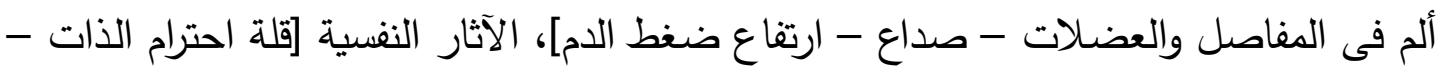
صعوبة فى تكوين العلاقات - سرعة الغضب - قلة التركيز - الخوف - اضطرابات النوم الوساوس القهرية] (http:// mawdoo3.com).

وأثارت نتائج الدراسة التى قامت بها "ميلند وجيان" (Melinda \& Jeanne, 2019)

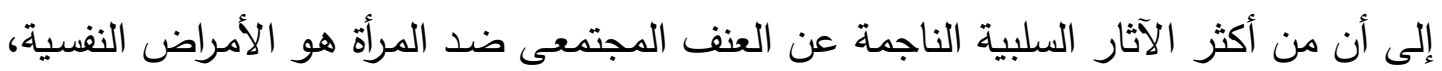
والتنكك الأسرى، وازياد الصراع فى الأسرة والمجتمع.

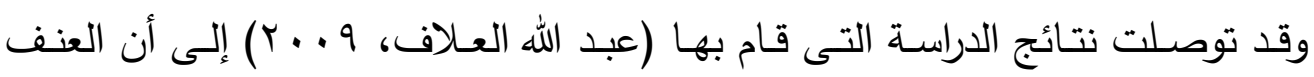
الأسرى يترك آثارًا سلبية على المرأة صحياً ونفياً واجتماعياً.

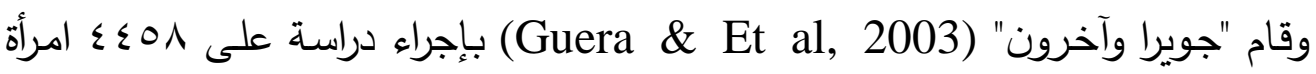

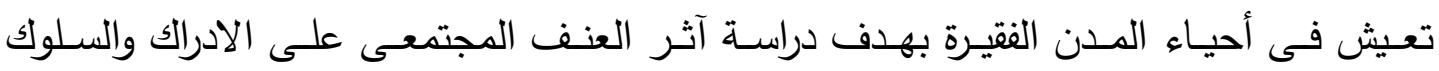
العدوانى، وأشارت النتائج إلى أن التعرض للعنف يتوقع منه أمراضًا نفسية وسلوكًا عدوانياً. 
وقد أشارت نتائج الدراسة التى قام بها "سيجر وآخرون" (Sieger \& Et al, 2004) إلى أن نسبة العنف المجتمعى ضد النساء والمراهقين مقلقة، حيث جاءت باءت بواقع متوسط وبنسبة

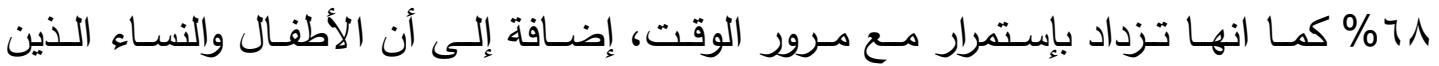

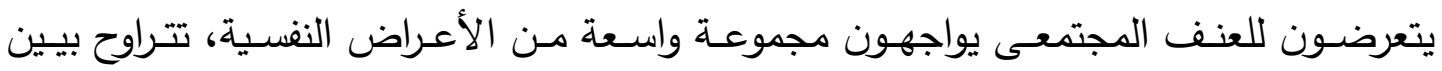

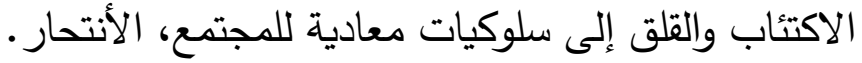

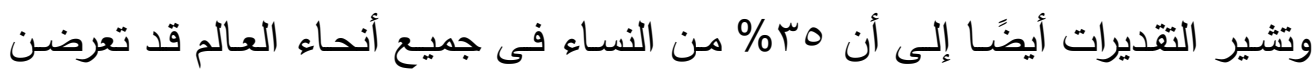

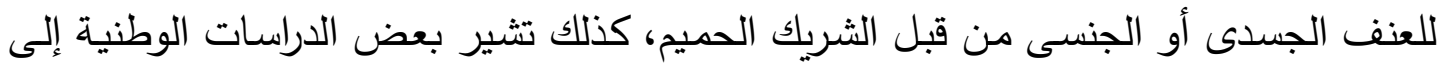

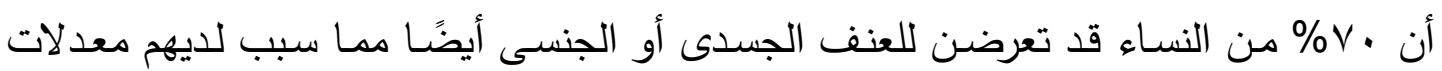

اكتئاب عالية ونقص المناعة (World Health Organization, 2013). والأزواج الذين يقومون بذلك النوع من التتمر أو العنف ضد زوجاتهم هم فى الغالب شاهدوا ذلك السلوك من قبل آباءهم وهم أطفال فنقلوه إلى زوجاتهم وفى لبنان كان احتمال ارتكاب العنف

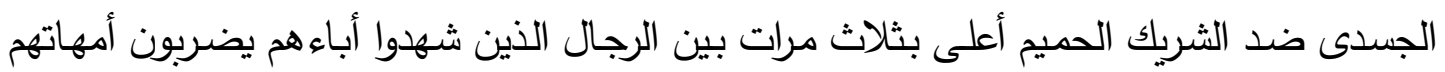
أثناء الطفولة مقارنة بمن لم يفعلوا ذلك (Promundo and un women, 2017).

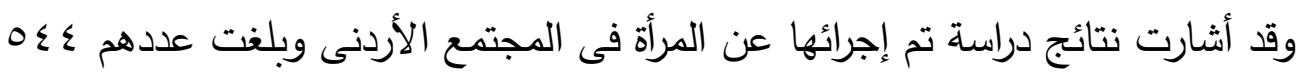

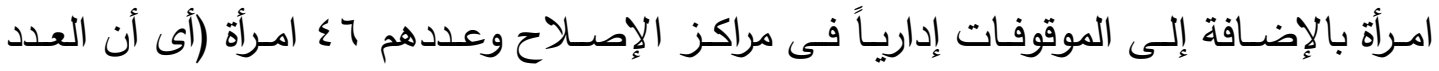

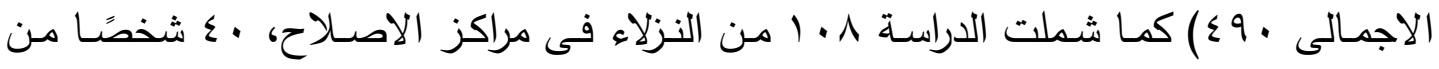

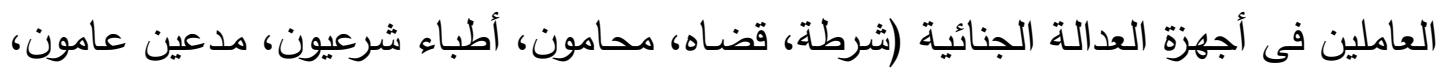

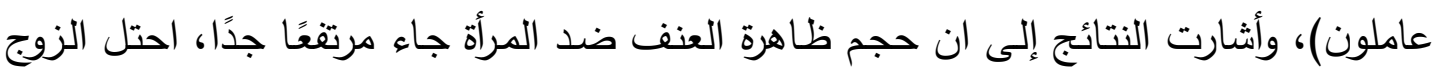

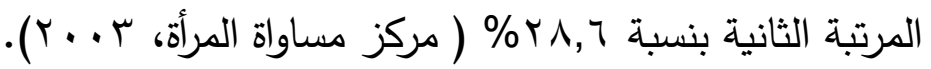

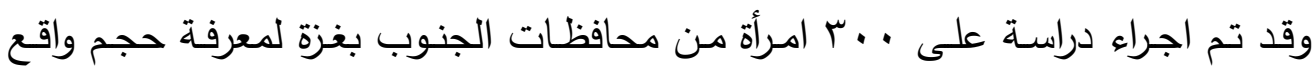

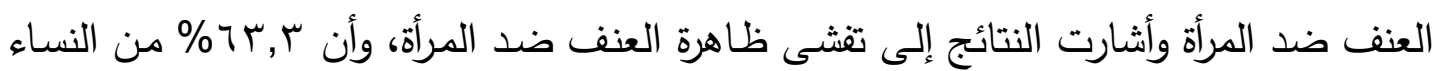

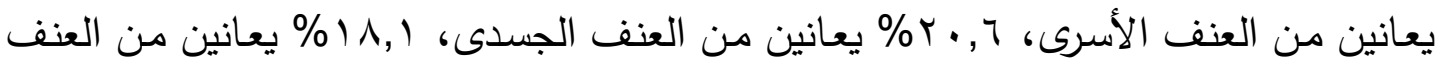

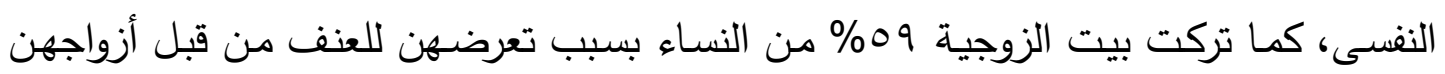

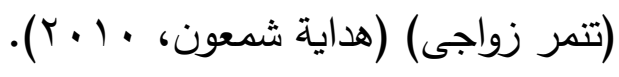

ومن خـلال تأمسل تلك الآثار نجد أن التتمر الذى يمارسه الزوج على زوجته بأشكال

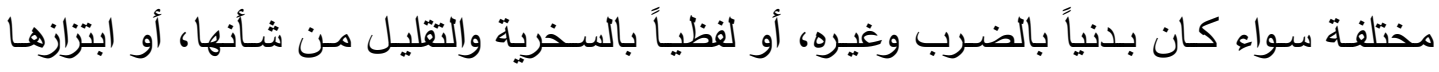


عاطفياً، أو كان انفعالياً كالتجاهل والعزلة، أو اتخذ شكل السيطرة عليها وعلى ممتلكاتها وشكل

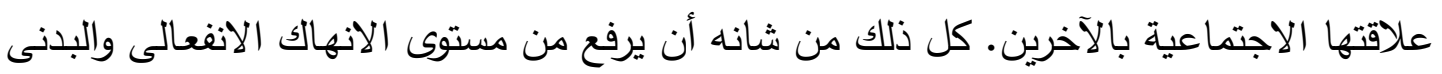

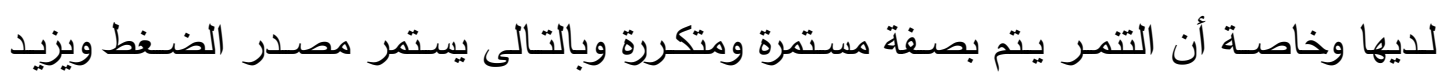
الاجهاد والارهاق لدى المرأة وتتغير نظرتها للأمور والحياة وتقل الحماسة ويزيد الأحباط وتحد من علاقاتها الاجتماعية بالآخرين، ويتدنى مفهوم الذات لديها فيزيد معدل الاحتراق النفسى.

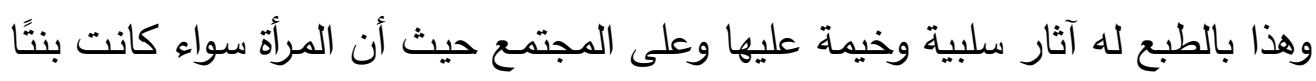

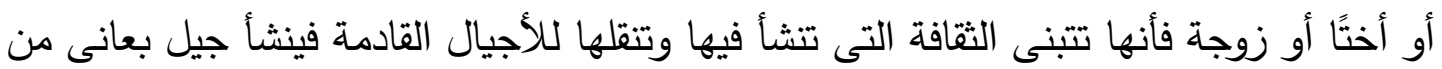

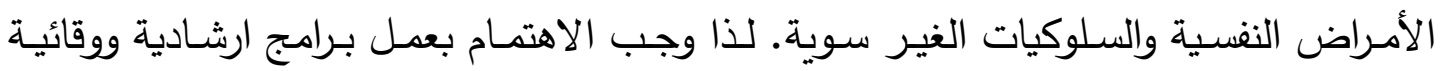

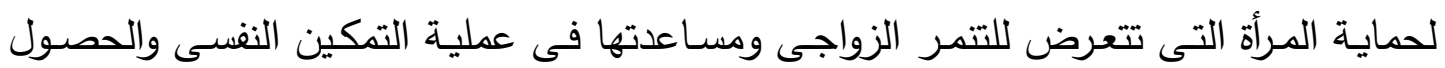
على حقوقها وحمايتها من الاحتراق النفسى للحفاظ عليها وعلى الأجيال القادمة.

الطرية

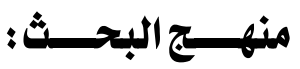

قامت الباحثة باستخدام المنهج الوصفى الارتباطى فى محاولة لوصف الظاهرة موضوع

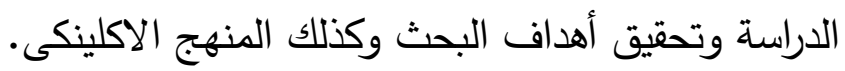

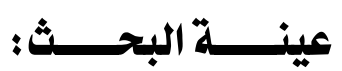

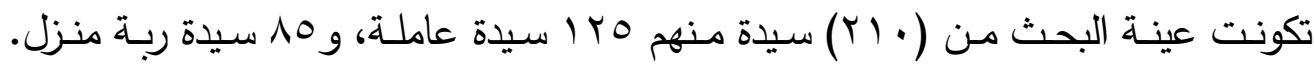

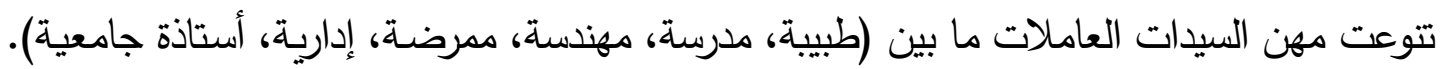

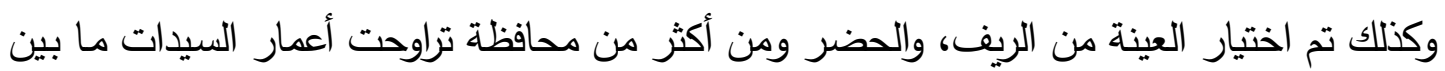

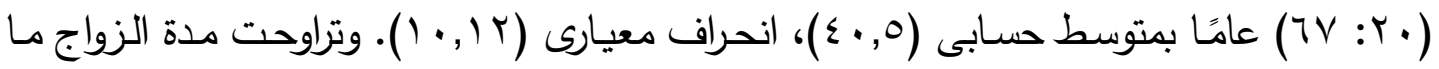

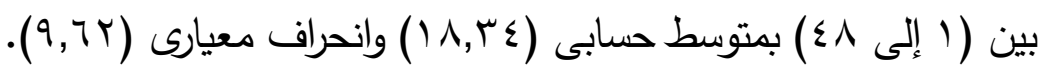

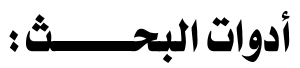
تحددت أدوات البحث فيما يلى: 1- مقياس التتمر الزواجى لاى المرأة (الضحية) (إعداد الباحثة). r- دقياس الاحتراق النفسى لدى المرأة (إعداد الباحثة). r- استمارة دراسة الحالة (إعداد الباحثة). ع - اختبار ساكس لتكملة الجمل الناقصة ( اعداد جوزيف ساكس ترجمه احمد سلامه ، و 1 ). 


\section{( ) مقياسر التنمر الزواجه لدى الهرأة (الضصية):}

أعدت الباحثة هذا المقياس بغرض قياس درجة التتمر التى تتعرض لها المرأة (الزوجة) فى إطار العلاقة الزواجية من الزوج باعتبارها أحد عناصر التتمر وهى (ضحية) ولإعداد هذا دأها

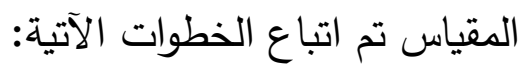
1- الاطلاعلاع على بعض الأدبيات والمقاييس التى تتاولت التتمر بكل صوره وأشكاله ودراسـة

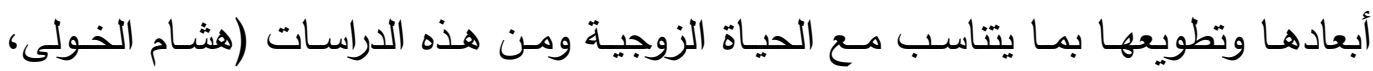

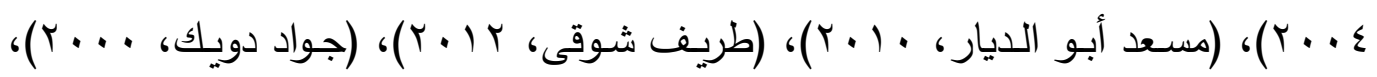

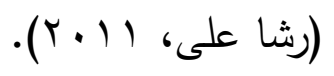

r-ولم تتوصل الباحثة إلى أى دراسة سواء عربية أو أجنبية تتاولت مصطلح التتمر الزواجى

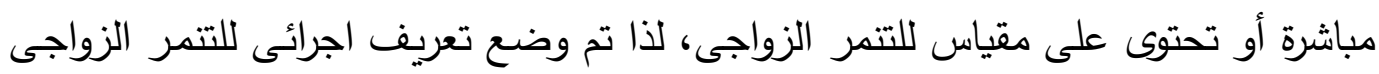
وأهم الأبعاد التى يتتاولها.

\section{التعريف الاجرائى للتنمر الزواجى للدى المرأة:}

يعرف التتمر الزواجى لدى المرأة والذى بنى على أساسه المقياس بأنه عبارة عن شكل

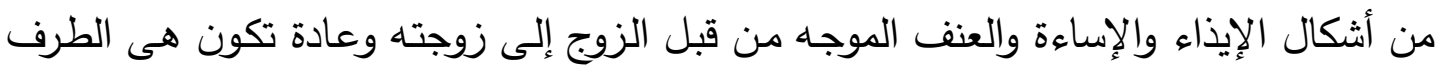

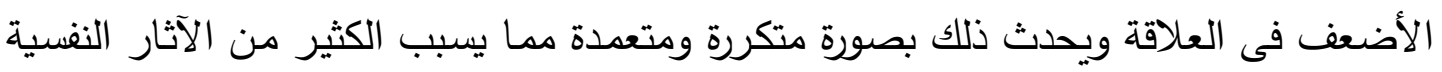
والبدنية والاجتماعية التى تؤدى إلى حدوث خلل واضح واضطراب فى العلاقة الزواجية.

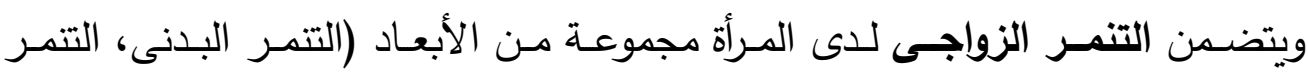
اللفظى، التتمر الانفعالى، الاستيلاء على الممتلكات، السيطرة الاجتماعية).

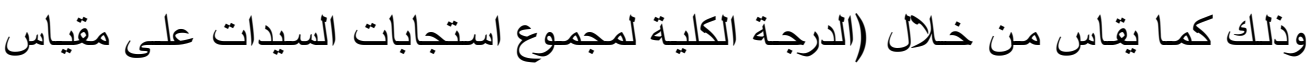
التنمر الزواجى المستخدم فى الدراسة الحالية)، وكان عدد العبارات التى تقيس هذه الأبعاد

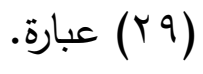

r- تم عرض الصورة الأولية للمقياس على مجموعة من المحكمين بلغ عددهم (خمسة) وهم

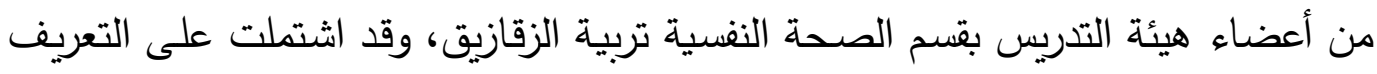
الاجرائى وكذلك تعريف كل بعد من الأبعاد التى يقيسها المقياس وطلب من سيادتهم الحكم على المقياس فى ضوء ما يلى:

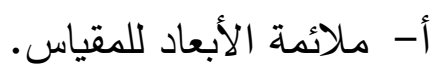




$$
\begin{aligned}
& \text { ب-انتماء العبارة للبعد. } \\
& \text { ج- الصياغة الملائمة للعبارة. } \\
& \text { د- إضافة أى ملاحظات أو مقترحات. }
\end{aligned}
$$

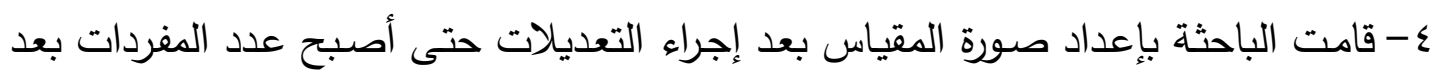
العرض على المحكمين (Y (Y) مفردة، وكذلك كان هناك توجه عام بعمل ه أبعاد للمقياس

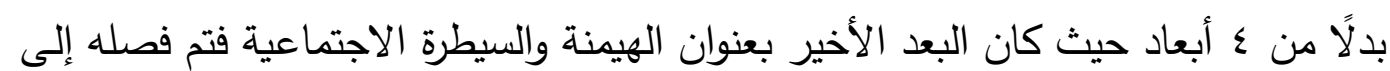

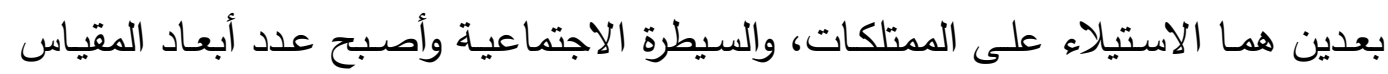

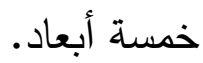

\begin{tabular}{|c|c|c|c|}
\hline 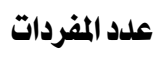 & أرقاه المفردات التى تقيس البعد & أبعاد مقياس التنهر الزواجى للدى المرأة & 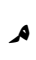 \\
\hline$\varepsilon$ & 17.11 .7 .1 & 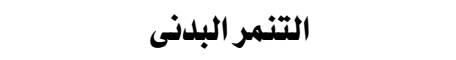 & 1 \\
\hline 0 & $r$ r Ir, Ir, r, r & التنمر اللفظى & r \\
\hline 0 & r & التنمر الانفعالى & $r$ \\
\hline$\varepsilon$ & $19 ، 1 \varepsilon ، 9.8$ & الاستيلاء على الممتلكات & $\varepsilon$ \\
\hline$\varepsilon$ & $r \cdot, 10,1 \cdot, 0$ & السيطرة الاجتماعية & 0 \\
\hline rr & \multicolumn{3}{|c|}{ المجموع الكلى للمفردات } \\
\hline
\end{tabular}

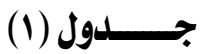

توزيع المفردات على أبعاد مقياس التنمر الزواجى للدى المرأة

ه- الخصائص السيكومترية للمقياس:

قامت الباحثة بتقنين المقياس وذلك من خـلال تطبيقه على عينـة قوامها ( •ـ) امرأة

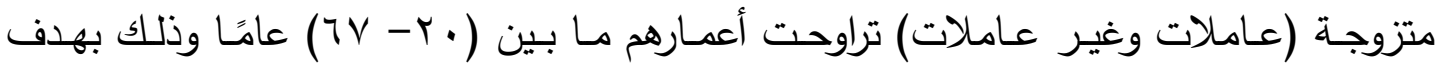
حساب ثباته وصدقه وذلك كما يلى: أ- الاتساوة الداظلكى:

تم حساب الاتساق الداخلى للمفردات عن طريق حساب ارتباط كل مفردة بالدرجة الكلية

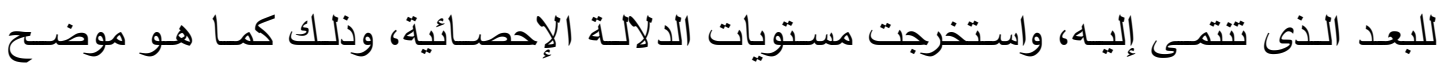
بالجدول(r) وقد اعتمدت الباحثة فى حساب الاتساق الداخلى للمفردات على معامل ارتباط "بيرسون" من خلال البرنامج الاحصائى (SPSS). 


\section{جلول (r)}

معاملات الارتباط بيز درجات مقياس التنمر الزواجى

للدى المرأةودرجات الابعاد الفرعية للمقياس (ن= •^ من السيلات المتزوجات)

\begin{tabular}{|c|c|c|c|c|c|c|c|c|c|}
\hline \multicolumn{2}{|c|}{ السيطرة الاجتماعية } & \multicolumn{2}{|c|}{ الاستيلاء على الممتلكات | } & \multicolumn{2}{|c|}{ التنمر الانفعالى } & \multicolumn{2}{|c|}{ التنمر اللفظى } & \multicolumn{2}{|c|}{ التنمر البلدى } \\
\hline معامل الارتباط & الرقه & | معامل الارتباط & الرقم & الارتباط معامل & 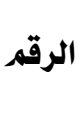 & الارتباط معامل & 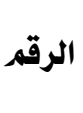 & الارتباط معامل & 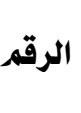 \\
\hline$* * \bullet, V \bullet \wedge$ & 0 & $* * \bullet$, rVY & $\varepsilon$ & $* * \bullet, \eta I r$ & $r$ & $* * \bullet,\rceil \xi \bullet$ & $r$ & $* * \bullet, \neg r r$ & 1 \\
\hline$* * \bullet, \vee Y 7$ & 1. & $* * \bullet, r \Lambda \bullet$ & 9 & $* * \bullet, \vee Y 7$ & $\Lambda$ & $* * \bullet, 01 Y$ & $\checkmark$ & ***, V々r & 7 \\
\hline$* * \bullet, Y \leqslant \varepsilon$ & 10 & $* * \bullet, O Y \wedge$ & $1 \varepsilon$ & **^, Irr & ir & $* * \bullet, \neg \vee V$ & ir & $* * \bullet,\urcorner \neg V$ & 11 \\
\hline$* * \bullet$, oor & r. & $* * \bullet, Y \wedge r$ & 19 & $* * \bullet, \nearrow Y \nearrow$ & M & **•, rAr & iv & $* * \bullet\rceil , r \varepsilon$ & 17 \\
\hline & & & & $* * \bullet,\{\vee q$ & rr & & rI & & \\
\hline
\end{tabular}

يتضـح مـن الجدول السـابق أن جميع معـاملات الارتباط دالة إحصـائياً عند ( ( . • )

$$
\begin{aligned}
& \text { وهذا يعنى ثبات جميع المفردات. } \\
& \text { ب-صــــ المقبـــاسر : }
\end{aligned}
$$

للتحقق من صدق المقياس استخدمت الباحثة الصدق العاملى بطريقة المكونات الأساسية

لهويبلينج وتدوير المحاور تدويرًا بطريقة فاريمكس لكايزر ، وأسفر التحليل عن وجود عامل واحد يتثبع بجميع أبعاد المقياس بدرجة جيدة من الصدق العاملى كما يوضحه الجدول التالى.

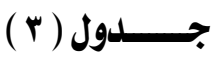

\begin{tabular}{|c|c|c|}
\hline الاشتراكات & التشبعات & الأبعاد \\
\hline$\cdot, 09$ & $\cdot, \vee \vee$ & التنمر البلدى \\
\hline$\cdot, \Lambda \cdot$ & $\cdot, 19$ & التنمر اللفظى \\
\hline •, $\vee 99$ & $\cdot, 19$ & التنمر الانفعالى \\
\hline$\cdot, n$ & $\cdot, \wedge \xi$ & الاستيلاء على الممتلكات \\
\hline$\cdot, 7$ & $\cdot, \vee v$ & السيطرة الاجتماعية \\
\hline & r,§^ & الجذز الكامن \\
\hline \multicolumn{2}{|c|}{$\% 79,7 r$} & نسبة التباين \\
\hline
\end{tabular}

الصلدق العاملى لمقياس التنمر الزواجى 


\section{م- ثبات المقياس Reliability}

اسـتخدمت الباحثة فـى حسـاب الثبات البرنـامج الإحصـائى (SPSS) وقد تم حسـاب

معامل الثبات بطريقة ألفا- كرونباخ (معامل ألفا)

\section{ويوضح جدول ( )}

معاملات ثبات مقياس التنهر الزواجى للدى المرأةباستخداه معادلة ألفا - كرونباخ

\begin{tabular}{|c|c|c|c|}
\hline معامل الثبات & عدد المفردات (ن) & أبعاد مقياس التنهر الزواجى & 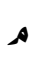 \\
\hline •, ATE & $\varepsilon$ & التنمر البلنى & 1 \\
\hline •, Y^ & 0 & التنمر اللفظى & $r$ \\
\hline$\cdot$, ATE & 0 & التنمر الانفعالى & $r$ \\
\hline., 79. & $\varepsilon$ & الاستيلاء على الممتلكات & $\varepsilon$ \\
\hline$\cdot, \wedge \leqslant 9$ & $\xi$ & السيطرة الاجتماعية & 0 \\
\hline •, 941 & rr & اللدجة الكلية & 7 \\
\hline
\end{tabular}

يتضـح من الجدول ( ع ) أن معاملات الثبات الخاصـة بأبعاد مقياس التنمر والدرجـة الكليـة للمقيـاس مناسـبة، ممـا يـدل على الاتسـاق الـاخلى لبنـود المقيـاس وبالتـالى صـلاحية

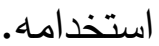

ج- بناء على الخصـائص السيكومترية للمقياس تم إعداد الصورة النهائية لـه والتى تكونت من ( r ع r عبارة) حيث لم يتم حذف عبارات بعد عمل الصدق والثبات والاتساق الداخلى.

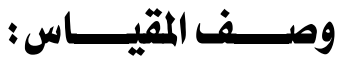

يتكـون مقيـاس التتمـر الزواجـى لـدى المـرأة مـن ه أبعـاد ينـدرج تحــ كـل منهــا

مجموعـة مـن المفـردات (العبـارات) وعـددها (Yr) مفـردة، تقـيس الأبعـاد الخمسـة التنمـر الزواجى لدى المرأة وهى: - منى

• التنمر البدنى Physical Bulling: ويعنى قيام الزوج بإيذاء الزوجة سواء بالضرب، أو

اللطم، أو العض، أو البصق فى وجهها، وكذلك تخربب الممتلكات الثخصية الخاصة بها. • التنمر اللفظى Verbal Bulling: ويعرف بأنـه قيام الزوج بالسخرية من زوجته أمـام الآخرين والتقليل من شأنها، ابتزازها عاطفياً، وكذلك إطلاق بعض الألقاب الغير محببة

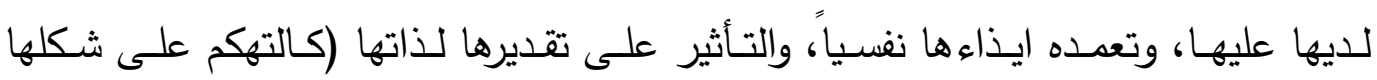


• التنمـر الانفعـالى Emotional Bullying: وهو يعنى التتمر العاطفى الذى يتضمن التجاهل، العزلة، العبوس، والإزدراء، الاستهزاء كالضحك بصوت منخفض مها يؤثر بشكل كبير على الزوجة وعلى تتبلها لذاتها. • الاستيلاء على الممتلكات: ويعنى تحكم الزوج فيما تملكه الزوجة من أثياء مادية ملموسة. " السيطرة الاجتماعية Social Control: وهى تعنى فرض الزوج السيطرة على شكل علاقة الزوجة بالآخرين مثل من تزور، المدة، من تقاطع، وهكذا.

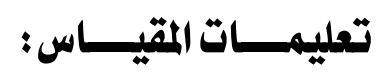

يطبق المقياس بصدوة فرديـة أو جماعية ولا توجد مدة محددة للإجابة على عبارات

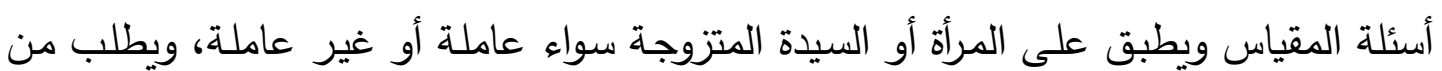
كل سيدة وضع علامة ( ل) أمام الاختيار الذى يتفق معها:

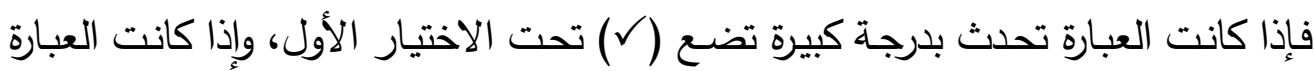

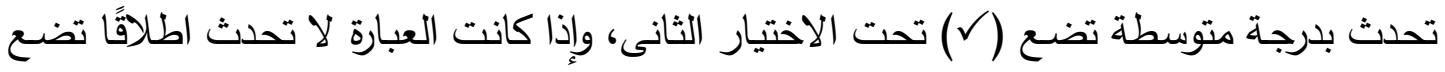
( ) تحت الاختيار الثالث مع التأكيد على عدم ترك عبارة بدون وضع علامة أمامها.

\section{تصحيح المقياس:}

\section{اعتمدت طريقة التصحيح على:}

"وضع درجة (†) إذا كان المفحوص تنطبق عليه العبارة بدرجة كبيرة. "وضع درجة (Y) إذا كان المفحوص تتطبق عليه العبارة بدرجة متوسطة. "وضع درجة (1) إذا كان المفحوص لا تتطبق عليه العبارة إطلاقًا. وبذلك نجد أن درجة المقياس تتراوح بين (1 - ؟7) درجة فى المقياس ككل.

\section{(ץ)مقياسر الاهتراق النفسى الدى المرأة (إعداد الباهثة):}

أعدت الباحثة المقياس بغرض قياس درجة الاحتراق النفسى لدى المرأة المتزوجة سواء

كانت عاملة أو غير عاملة ولإعداد هذا المقياس تم اتباع الخطوات التالت دالية: 1- الاطـلاع على بعض الأدبيات التى تتاولت الاحتراق النفسى ومـا تتضمنه مـن مقاييس

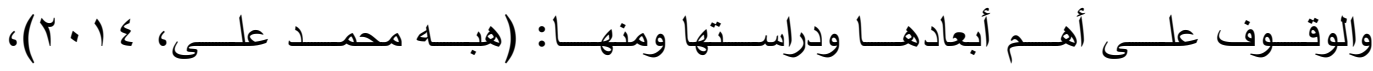

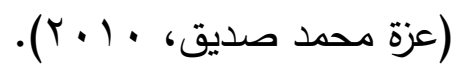




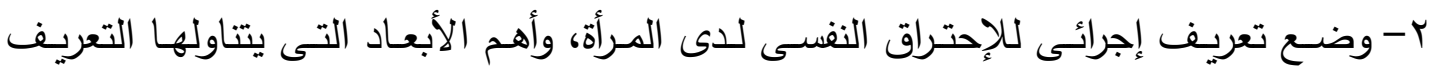

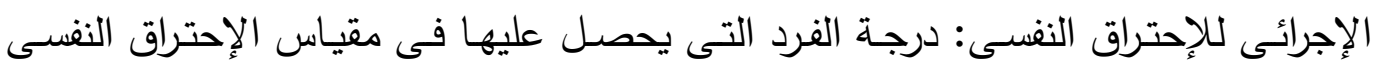

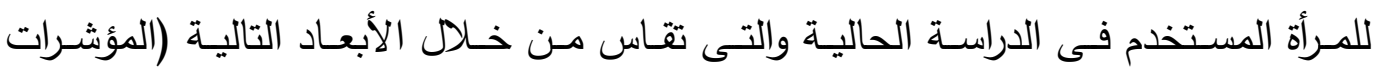

$$
\text { الجسمية، المؤشرات السلوكية، المؤشرات العاطفية). }
$$

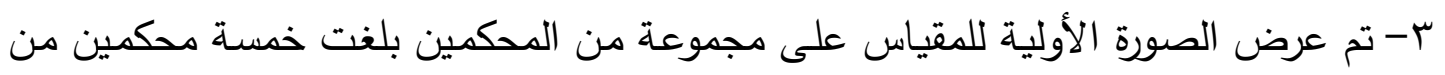

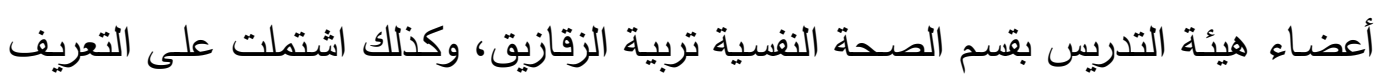

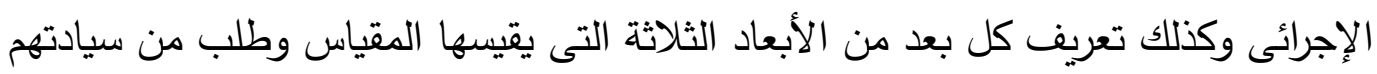

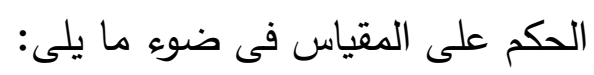
أ- أ- ملائمة الأبعاد للمقياس.

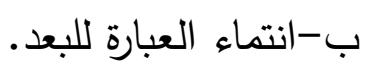
ج- الصياغة الملائمة للعبارة. د- إضافة أى ملاحظات أو اقتراحات. ع- قامت الباحثة بإعداد الصورة النهائية وقد اتفق المحكمين على جميع عبارات المقياس ولم

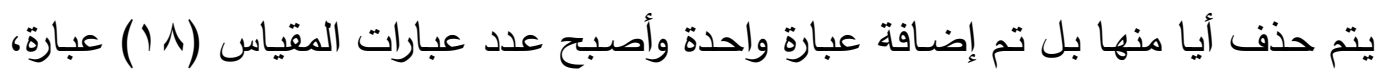
ويوضح جدول ( 0 ) توزيع الدفردات على أبعاد مقياس الأحتراق النفسى لدى المرأة.

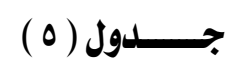

\begin{tabular}{|c|c|c|c|}
\hline 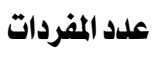 & أرقام المفردات التى تقيس البعد & أبعاد مقياس الاحتراق النفسى & 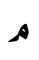 \\
\hline 0 & Ir. & مؤشرات جسلية & 1 \\
\hline v & $11,17,1 \varepsilon, 11,1,0, r$ & مؤشرات سلوكية & $r$ \\
\hline 7 & IV.10, Ir.9.7. & مؤشرات عاطفية & $r$ \\
\hline M & 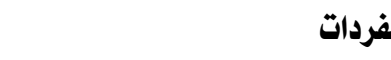 & 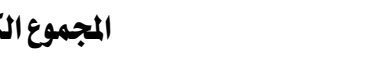 & \\
\hline
\end{tabular}

\section{توزيع المفردات على أبعاد مقياس الاحتراق النفسى للدى المرأة}

ه- الخصائص السيكومترية للمقياس

قامت الباحثة بتقنين المقياس وذلك من خلال تطبيقه على عينـة قوامها (ــ (م) امرأة

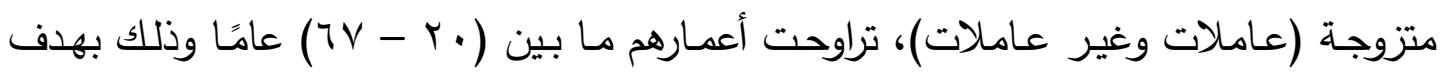
حساب ثباته وصدقه كما يلى: 


\section{أ- الاتسباو الداخلى:}

تم حساب الاتساق الداخلى للمفردات عن طريق حساب ارتباط كل مفردة بالدرجة الكلية

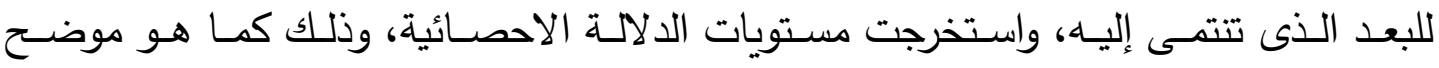
بالجدول ( 7 )، وقد اعتمدت الباحثة فى حساب الاتساق الدلخلى للمفردات على معامل ارتباط "بيرسون" من خلال البرنامج الاحصائى (SPSS).

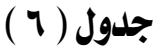

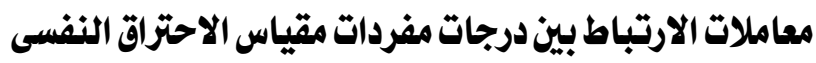

للدى المرأة ودرجات الأبعاد الفرعية للمقياس (ذ= •^م من السيدات المتزوجات)

\begin{tabular}{|c|c|c|c|c|c|}
\hline \multicolumn{2}{|c|}{ مؤشرات عاطفية } & \multicolumn{2}{|c|}{ مؤشرات سلوكية } & \multicolumn{2}{|c|}{ مؤشرات جسمية } \\
\hline معامل الارتباط & الرقم & معامل الارتباط & الرقم & معامل الارتباط & الرقم \\
\hline **•, ¿ाץ & $r$ & $* * \bullet, r \cdot V$ & $r$ & $* * \bullet, \leqslant q \bullet$ & 1 \\
\hline **•, rIr & 7 & $* * \cdot, r \cdot 0$ & 0 & $* * \bullet, 09 V$ & $\varepsilon$ \\
\hline **•, ory & 9 & **•,ZYr & $\wedge$ & $* * \bullet,\{\Lambda \bullet$ & v \\
\hline$* * \cdot, 0.7$ & ir & $* * \bullet, 701$ & 11 & **•, ๆட• & 1. \\
\hline$* * \bullet,\{Y \mid$ & 10 & $* * \bullet,\{11$ & $1 \varepsilon$ & ***, rar & ir \\
\hline \multirow[t]{2}{*}{$* * \bullet,\rceil \leq Y$} & iv & $* * \bullet, \operatorname{lrr}$ & 17 & & \\
\hline & & $* * \bullet$, orr & in & & \\
\hline
\end{tabular}

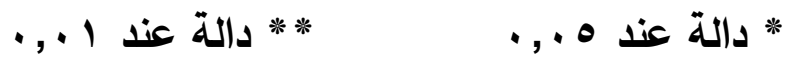

يتضـح من الجدول السابق أن جميع معاملات الارتباط دالة إحصائياً عند (1 . . •) وهذا

$$
\text { بعنى ثبات جميع المفردات. }
$$

للتحقق من صدق المقياس استخدمت الباحثة الصدق العـاملى بطريقة المكونات الأساسية

لهوتلينج وتدوير المحاور تدويرًا متعامدًا بطريقة فاريماكس لكايزر ، وأسفر التحليل عن وجود عامل بطل واحد يتشبع بجميع أبعاد المقياس بلرجة جيدة من الصدق العاملى، كما يوضحه الجدول التالى.

\begin{tabular}{|c|c|c|}
\hline الاشتراكيات & التشبعات & الأبعــــــــاد \\
\hline$\cdot, 79$ & $\cdot \overrightarrow{A N}$ & مؤشرات جسمية \\
\hline$\cdot, Y V$ & $\cdot, \wedge \wedge$ & مؤشرات سلوكية \\
\hline$\cdot, 79$ & $\cdot, A r$ & مؤشرات عاطفية \\
\hline & $r, 10$ & الجذر الكامن \\
\hline \multicolumn{2}{|c|}{$\% \vee r, 71$} & نسبة التباين \\
\hline
\end{tabular}

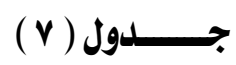

الصلدق العاملى لمقياس الاحتراق النفسى للدى المرأة 


\section{م-ثبات المقياس Reliability}

استخدمت الباحثة فى حساب الثبات البرنـامج الاحصـائى (SPSS) وقد تم حساب

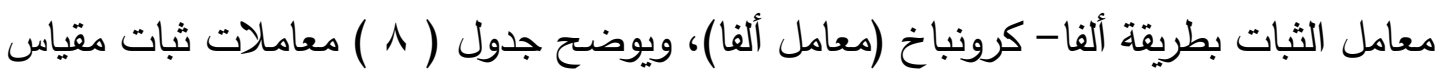
الاحتراق النفسى لدى المرأة باستخدام معادلة ألفا- كرونباخ.

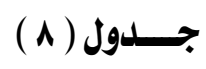

معاملات ثبات مقياس الاحتراق النفسى باستخدام معادلة ألفا- كرونباخ

\begin{tabular}{|c|c|c|c|}
\hline معامل الثبات & عدد المفردات (ذ) & أبعاد مقياس الاحتراق النفسى & هـ \\
\hline - , vol & 0 & مؤشرات جسلية & 1 \\
\hline •, rra & r & مؤشرات سلوكية & $r$ \\
\hline - rro & 1 & مؤشرات عاطفية & $r$ \\
\hline -AVI & in & الدرجة الكلية للمقياس & $\xi$ \\
\hline
\end{tabular}

يتضح من الجدول ( ^ ) أن معاملات الثبات الخاصة بأبعاد مقياس الاحتراق النفسى

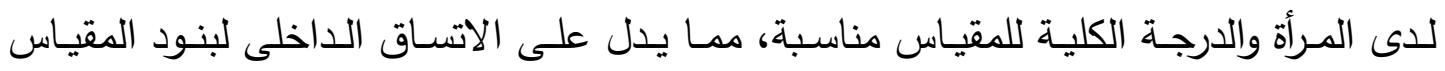
وبالتالى صلاحية استخدامه.

1- بناء على الخصائص السيكومترية للمقياس تم اعداد الصورة النهائية له والتى تكونت من (1/1) عبارة حيث لم يتم حذف أى عبارة بعد عمل الصدق والثبات والاتساق الداخلى.

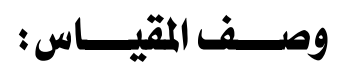

يتكون مقياس الاحتراق النفسى لاى المرأة من ثلاثة أبعاد يندرج تحت كل بعد مجموعة

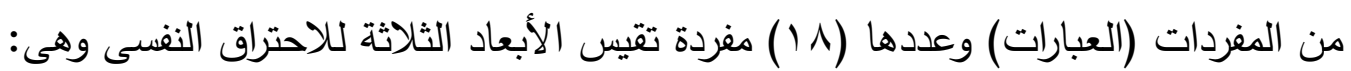

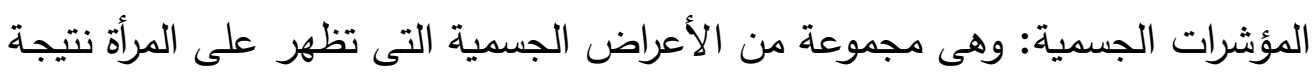

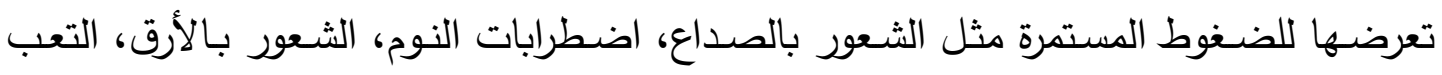
المستمر واستتزاف الطاقة.

المؤشـرات السـلوكية: وهـى تتضــن الآثـار السلوكية التـى تظهـر على المـرأة نتيجـة

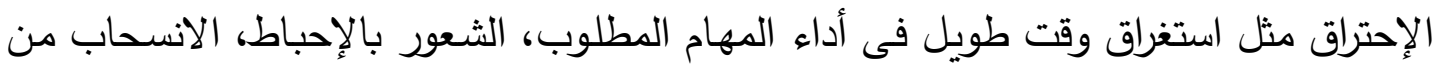

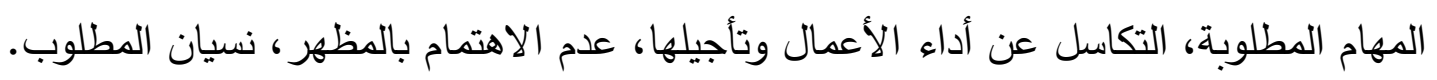

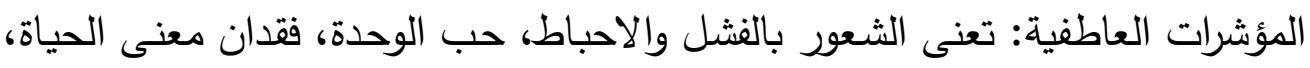
فقدان الدافعية للعمل، عدم الرضا عن الحياة. 


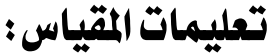

يطبق المقياس بصورة فرديـة أو جماعية ولا توجد مدة محددة للإجابة على عبارات

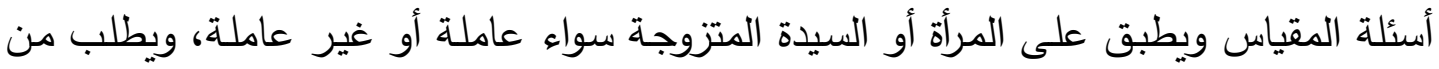
كل سيدة وضع علامة ( ل) أمام الاختيار الذى يتفق معها:

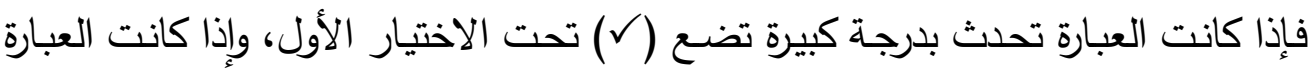

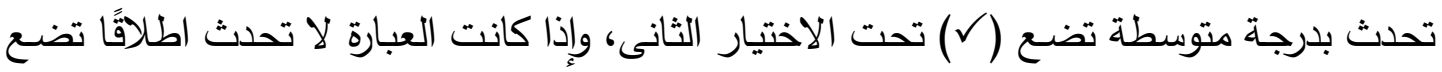

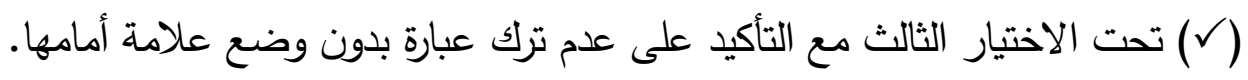

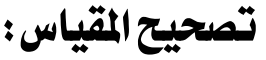

\section{اعتمدت طريقة التصحيح على:}

وضع درجة (ץ) إذا كان المفحوص تتطبق عليه العبارة بدرجة كبيرة. • وضع درجة (Y) إذا كان المفحوص تنطبق عليه العبارة بدرجة متوسطة. وضع درجة (1) إذا كان المفحوص لا تتطبق عليه العبارة إطلاقًا.

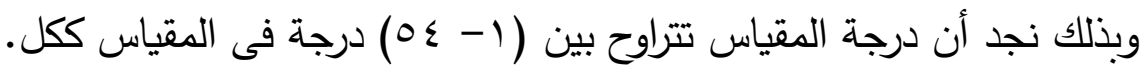

\section{(") استمارة دراسة الهالة (إعداد الباحثة)::}

وتتكون دراسة الحالة من: (تركيبة الأسرة، التاريخ الأسرى، الحالة الصحية، العلاقات

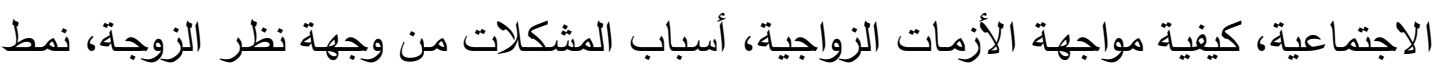
الحياة، كيفية إدارة الوقت، الهوايات، النظرة للمستقبل، المخاوف).

(غ) افتبار ساكسر لتكملة الجمل:

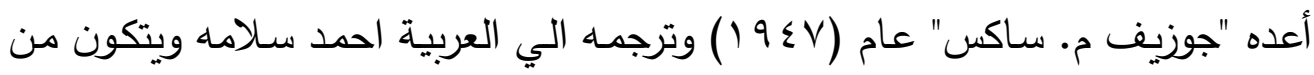
. 7 عبارة ناقصة تدور حول أربع مجالات: • الأولى: مجال الأسرة: الاتجاه نحو الأم، والأب، ووحدة الأسرة. " الثانى: مجال الجنس: الاتجاه نحو النساء، والعلاقات الجنسية الغيرية.

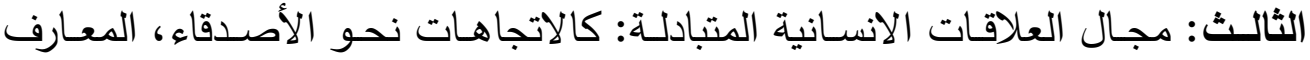
وزملاء العمل أو الددرسة، رؤساء العمل أو الددرسة، المرؤسين.

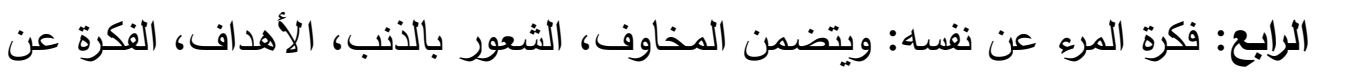
القدرات، الفكرة عن الماضى، وعن المستقبل. 
وتقدر الاستجابات طبقًا لمدى ملاءمة تكملة كل جملة فى الكثف عن الاتجاه الذى

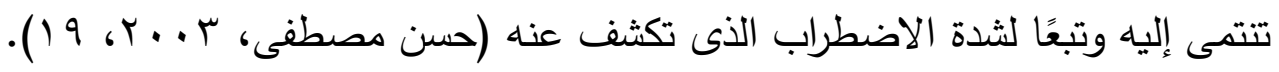

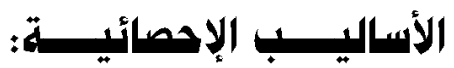

تم استخدام الأساليب الإحصائية التالية:

$$
\text { "معامل الارتباط البسيط لبيرسون }
$$

•اختبار (ت) لدالة الفروق بين المتوسطات T. Test

• تحليل التباين ثنائى الاتجاه (r × r r)

• ت تحليل التباين البسيط

Stepwise. R. تحليل الانحدار متعدد الخطوات

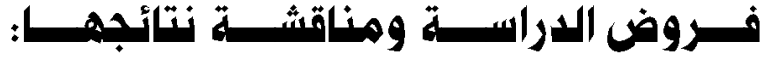

أولاً : نتائج الفرض الأول : أو

ا 1- الفــــرض الأول

سوف تعرض الباحثة نتائج الفرض الاول في ثلاث خطوات، في الخطوة الاولي سيتم

معالجة معاملات الارتباط بين درجات متغير التتمر الزواجي ودرجات متغير الاحتراق النفسي

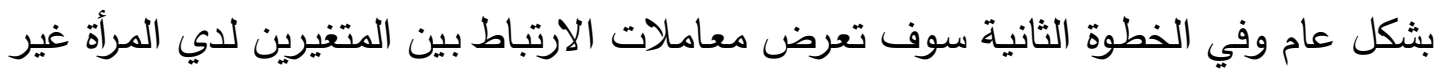
العاملة ثم معاملات الارتباط بين المتغيرين لدي المرأة العاملة كالاتي :

الجزء الاول " توجد علاقة ارتباطية ذات دلالـة إحصـائية بين درجـات متغير التنــر

$$
\text { الزواجى ودرجات متغير الاحتراق النفسى ". }
$$

ولاختبار صحة الفرض، تم حساب معامل ارتباط (بيرسون) لفحص اتجاه وقوة العلاقة

$$
\text { بين التتمر الزواجى، والاحتراق النفسى، وذلك من حيث: }
$$

• العلاقة بين أبعاد التتمر الزواجى وأبعاد الاحتراق النفسى لدى المرأة.

العلاقة بين الدرجة الكلية للتمر الزواجى والدرجة الكلية للاحتراق النفسى لدى المرأة.

$$
\text { كما يتضح في جدول ( } 9 \text { ( ). }
$$




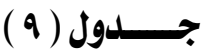

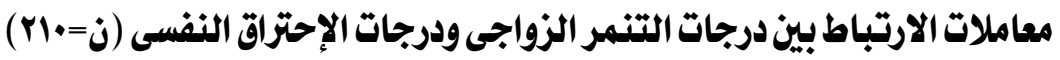

\begin{tabular}{|c|c|c|c|c|}
\hline للاحتراق النفسى الكلية & مؤشرات عاطفية & مؤشرات سلوكية & مؤشرات جسمية & الاحتراق \\
\hline$* *$ * rar & $* *$, rar & $* * \bullet$, r $\leq \varepsilon$ & $* * \bullet$, ros & التنمر البدنى \\
\hline$* * \cdot$ OAV & **, oro & **•, orz & **, §Yษ & التنمر اللفظى \\
\hline$* * \bullet$, OrA & $* * \bullet,\{V r$ & $* * \bullet, 01$ & $* * \bullet,\{\wedge \xi$ & التنمر الانفعالى \\
\hline$* * \bullet,\{0 \wedge$ & $* * \bullet,\{r V$ & **•, זฯ & **•, riv & الاستيلاء على الممتلكات \\
\hline ***, \&ly & ***,rVr & $* * \bullet, r q$. & $* * \cdot$ TY & السيطرة الاجتماعية \\
\hline$* * \bullet, 09$ & $* * \bullet, 0 \& 1$ & $* * \cdot, 011$ & $* * \bullet,\{\xi 1$ & الدرجة الكلية للتنمر الزواجى \\
\hline
\end{tabular}

(1) توجد علاقة ارتباطية ذات دلالة إحصائية موجبة عند (1 . •) بين درجات التنمر البدنى

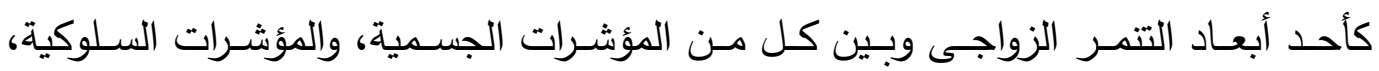
والمؤشرات العاطفية كأبعاد أساسية للاحتراق النفسى وكذلك الدرجة الكلية للاحتراق النفسى.

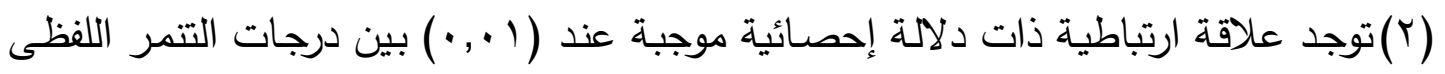
كأحد أبعاد التنمر الزواجى وكل من المؤشرات الجسمية، والمؤشرات السلوكية، والمؤشرات العاطفية كأبعاد أساسية للاحتراق النفسى وكذلك الدرجة الكلية للاحتراق النفسى.

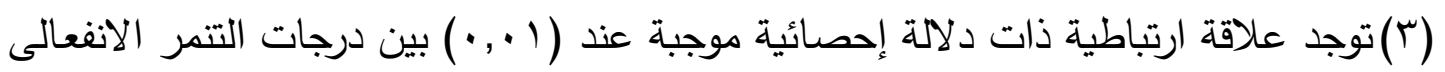
كأحد أبعاد التتمر الزواجى وكل من المؤشرات الجسمية، والمؤشرات السلوكية، والمؤشرات العاطفية كأبعاد أساسية للاحتراق النفسى وكذلك الدرجة الكلية للاحتراق النفسى.

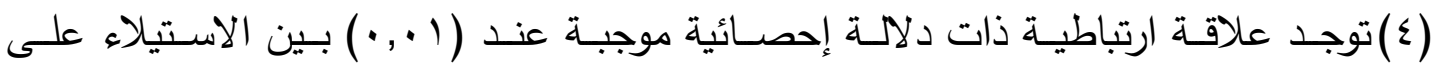
الممتلكات كأحد أبعاد التتمر الزواجى وكل من المؤشرات الجسمية، والمؤشرات السلوكية، الماتهة والمؤشرات العاطفية كأبعاد أساسية للاحتراق النفسى وكذلك الدرجة الكلية للاحتراق النفسى.

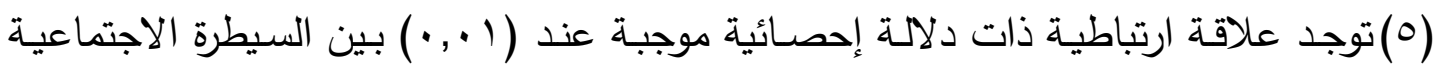
كأحد أبعاد التتمر الزواجى وكل من المؤشرات الجسمية، والمؤشرات السلوكية، والمؤشرات العاطفية كأبعاد أساسية للاحتراق النفسى وكذلك الدرجة الكلية للاحتراق النفسى. 
(ך) توجد علاقة ارتباطية ذات دلالـة إحصـائية موجبة عند (1 •, •) بين الدرجة الكلية للتنمر الزواجى وكل من المؤشرات الجسمية، والمؤشرات السلوكية، والمؤشرات العاطفيـة كأبعاد

أساسية للاحتراق النفسى وكذلك الدرجة الكلية للاحتراق النفسى.

ويمكن تفسير ذلك بأن التنمر الذى يمارسه الزوج ضد زوجته أيا كان نوعه تتمرًا بدنياً

بالضرب والإهانة، أو لفظياً بالسخرية منها والتقليل من شأنها أمام الآخرين واستخدامه لأسلوب الابتزاز العاطفى، أو كان انفعالياً كأن يتجاهل رأيها أو وجودها فى وجود الآخرين، أو اتخذ التتمر شكل الاستيلاء على ممتلكاتها الخاصـة واعتبارها حكرًا لله، أو اتخذ شكل السيطرة على التى علاقتها بالآخرين كالأهل والأصدقاء وغيرهم كل هذا من شـأنه أن يسببً نوعًا من الضـــ المستمر عليها وقد يصـل لمرحلـة استتزاف الطاقة أو الانهاك الانفعـالى فتبـدأ ظهور أعراض الاحتراق النفسى عليها كالمؤشرات الجسمية فتشعر بالأرق، الصداع، آلام فى المفاصل وتتفق

$$
\text { الباحثة مع دراسة كل من (ليلى مرح، } 9 \text { × . r)، ( محمد مروان، } 9 \text { 1 •r). }
$$

وقد تظهر المؤشرات السلوكية فتنسح من بعض المهام المطلوب منها، وتتكاسل عن

أداء بعض الأعمال نتيجة غياب التقدير من الطرف الآخر ، وقد تهمل فى مظهرها بسبب ما يسببه الزوج المتتمر من الإنطفاء الذاتى، وقد أشارت دراسة (Ravneet \& Suneela, 2008) إلى أن تعرض المرأة للعنف من شريك الحياة يجعلها لا تشـارك فى الأنشطة المختلفة وعدم القدرة على أداء العمل وكذلك عدم التمكن من الاعتناء بنفسها وبأطفالها. وقد تظهر على الزوجـة الضـحية أيضًا بعض المؤشـرات العاطفيـة كالثـعور بالفشل كل

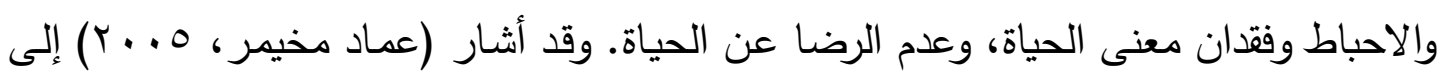
أن الاساءة التى تتعرض لها المرأة من زوجها تسبب لها الشعور بانخفاض قيمة الذات. وترى الباحثة أن ذلك من شأنه أن يفقدها معنى الحياة فكيف تشعر بمعنى الحياة وهى لا تشعر بقيمتها اتجاه ذاتها ؟.

في هذا الاتجاه أشارت "ديوب سيدياب وآخرون" (Diop- Sidibe \& etal, 2006)

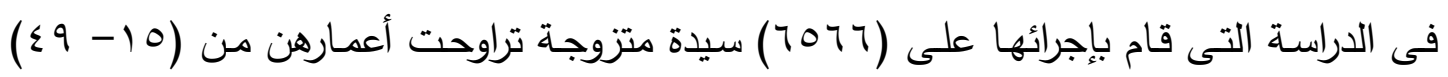

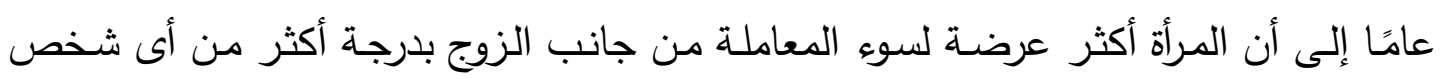
آخر ، وأن كثيرًا من الآثار الصحية السلبية للضحايا مرتبطة بالعنف المنزلى ضد المرأة. 
الجزء الثاني : معـاملات الارتباط بين درجات أبعاد التنمر الزواجي ودرجات أبعاد

الاحتراق النفسي لدي ربات البيوت " المرأة غير العاملة " (رغبة من الباحثة في التعرف علي طبيعـة معاملات الارتباط بين المتغيرين في حالات خاصـة في ضـوء ممارسـة العمل او عدم ممارسـته فقد عرضــت معـاملات الارتبـاط في حـالتين (عمل ولا عمـل) كمـا في الجـدولين

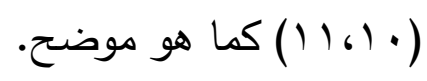

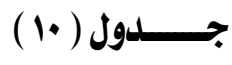

معاملات الارتباط بين التنمر الزواجى وأبعاد الاحتراق النفسى للدى ربات البيوت ( المرأة غير العاملة ن = 10 )

\begin{tabular}{|c|c|c|c|c|}
\hline للاحتراق النفسى الكلية & مؤشرات عاطفية & مؤشر ات سلوكية & مؤشرات جسمية & الاحتراق \\
\hline$* * \bullet,\{1\}$ & $* * \bullet,\{\cdot 1$ & $* \bullet$, rTA & $* * \bullet, r Y r$ & التنهر البلى \\
\hline$* * \bullet$, orr & $* * \cdot,\{0\}$ & $* * \cdot,\{\cdot 0$ & $* * \cdot$, rVq & التنمر اللفظى \\
\hline$* * \bullet$, orA & **•, \&YY & $* * \cdot$, rOA & ***, हV. & التنمر الانفعالى \\
\hline ***, rro & $* *$, rAv & 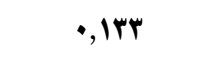 & $* \cdot$, YOq & الاستيلاء على الممتلكات \\
\hline$\cdot, r \cdot r$ & • & $\cdot, 11 r$ & $* \cdot$, TYE & السيطرة الاجتماعية \\
\hline \multirow[t]{2}{*}{$* * \bullet,\{97$} & $* * \bullet, \llbracket ६ \bullet$ & $* * \bullet, r l$ & $* * \bullet, \xi \bullet \wedge$ & اللدرجة الكلية للتنمر الزواجى \\
\hline & & \multicolumn{2}{|c|}{ *** دالة عند ا •, • } & 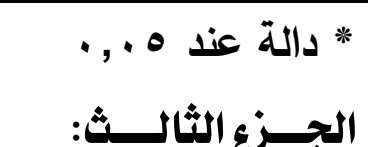 \\
\hline
\end{tabular}

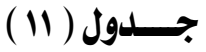

معاملات الارتباط بيز التنمر الزواجى وأبعاد الاحتراق النفسى لدى المرأة العاملة ( ذ=1 ا )

\begin{tabular}{|c|c|c|c|c|}
\hline للاحتراق النفسى الكلية & مؤشرات عاطفية & مؤشرات سلوكية & مؤشرات جسمية & \\
\hline$* * \bullet$, roo & $* * \bullet, r 7 q$ & $* * \cdot, r q 1$ & $\cdot, 1 \leqslant r$ & التنهمر البلنى \\
\hline$* * \bullet, 71 \xi$ & $* * \bullet$, ov 7 & $* * \bullet, 0 \wedge 7$ & ***,รrฯ & التنمر اللفظى \\
\hline$* * \bullet, 7 \cdot 1$ & $* * \bullet, 0 \cdots$ & $* * \bullet, 097$ & $* * \bullet, \Sigma 9 々$ & التنمر الانفعالى \\
\hline$* * \bullet, 0 \leqslant 1$ & ***, orq & $* * \cdot, 0 \cdot 1$ & ***, ros & الاستيلاء على الممتلكات \\
\hline$* * \bullet, 000$ & **•, or• & $* * \bullet, 01 \bullet$ & $* * \bullet, \zeta \bullet \bigvee$ & السيطرة الاجتماعية \\
\hline$* * \bullet, 7 \leqslant 1$ & $* * \bullet, 09 \mathrm{~V}$ & $* * \bullet, 719$ & $* * \bullet,\{\& \Lambda$ & الدرجة الكلية للتنمر الزواجى \\
\hline
\end{tabular}

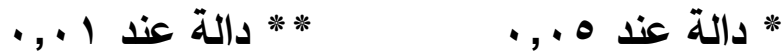




\section{ويتضح من الجدولين ما يلى:}

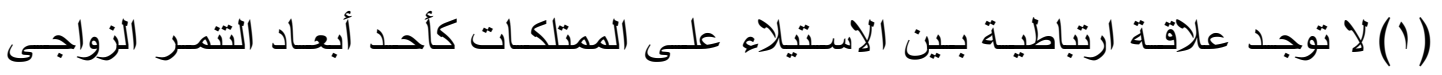

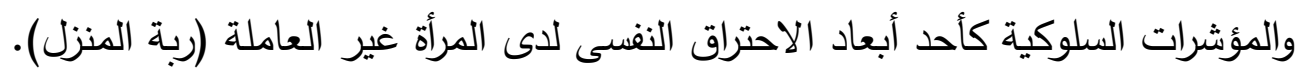

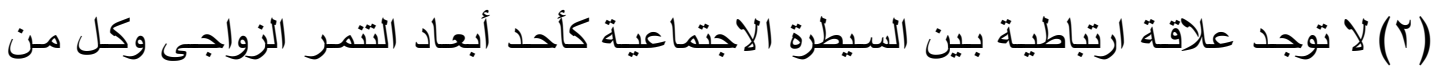

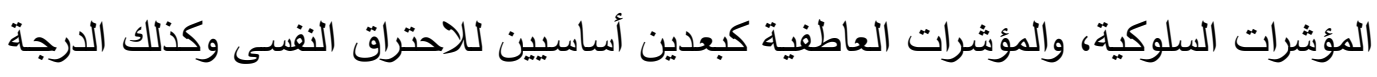

الكلية للاحتراق النفىى لدى المرأة غير العاملة (ربة المنزل).

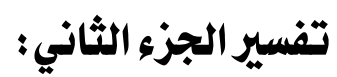

ويمكن تفسير ذلك بأن المرأة غير العاملة تعتبر لا تمتلك شيئًا مادياً وغير مشاركة فى العى

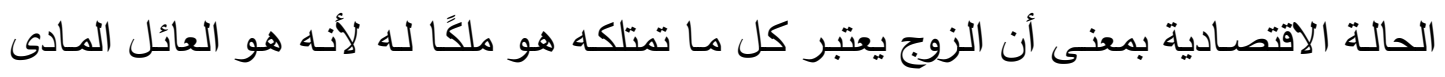

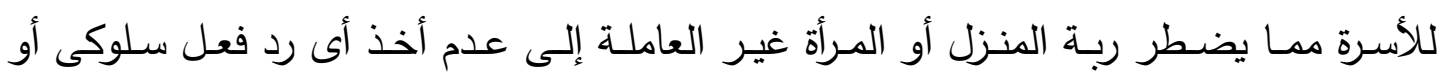
انسحابى فى الحياة الزوجية بل بالعكس من الممكن تحاول الوصول إلى التوازن فى حياتها بإتقان ما هو مطلوب منها اتجاه الأسرة فلا تنسحب من مهامتها ولا تتكاسل عن أداء أعمالها المنزلية والأسرية.

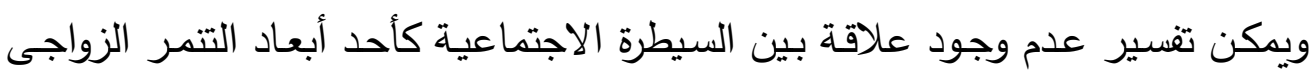

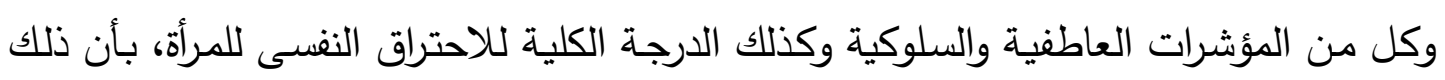

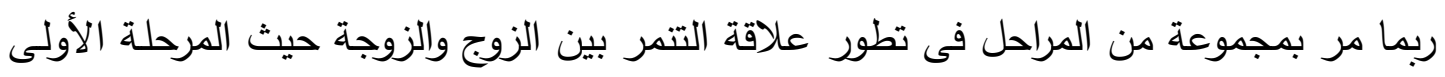

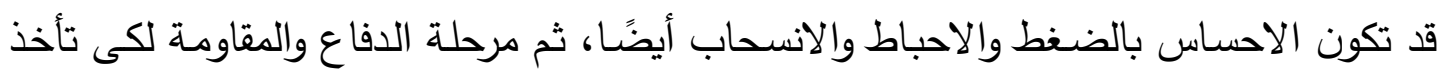

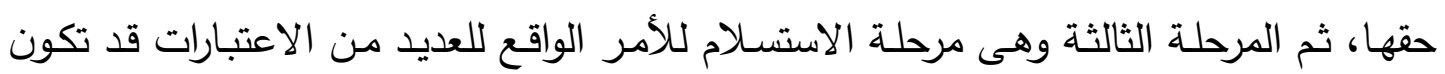

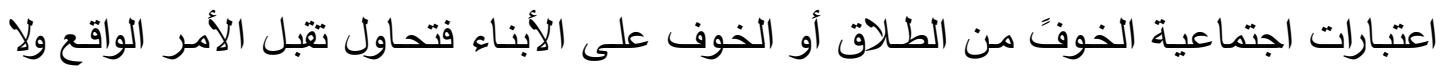

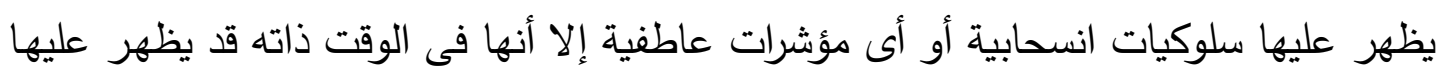

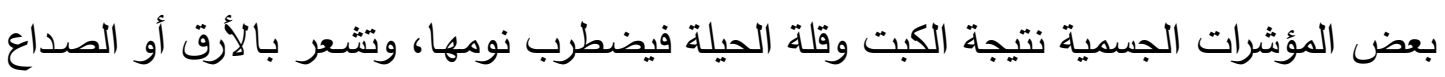

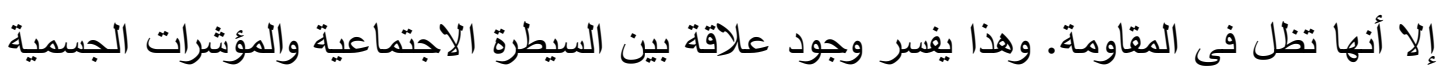

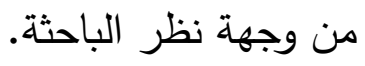

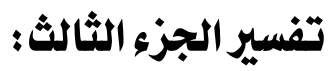

- لا توجد علاقة ارتباطية دالة بين التتمر البدنى كأحد أبعاد التتمر الزواجى والمؤشرات

الجسمية كأحد أبعاد الاحتراق النفسى لدى المرأة العاملة. 
ويمكن تفسير ذلك بأن عمل المرأة يكسبها نوعًأ من المكانة والثقل فى الأسرة بإعتبارها عنصرًا مشاركًا للرجل مما لا يدفعه أيا كانت الأسباب إلى القيام بالتتمر البدنى عليها وإلا اختل توازن المنزل مادياً. وقد أشـارت نتائج الدراسـة التى قامت بها (أمل العواودة، ؟ . . ب) إلى أن واقع ظاهرة العنف ضد المرأة جاء متوسطًا حيث أن عمل المرأة قد انحصر فى مجمله فى الأعمال التربويـة والاجتماعية والإدارية.

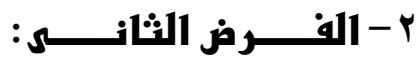

يــص الفـرض الثاني علي انـهـ : " تتبـئ بعـض أبعـاد التتمـر الزواجـى دون غيرهـا بالاحتراق النفسى لدى المرأة ".

ولاختبار صحة هذا الفرض تم حساب معادلة الانحدار ، لتحديد مدى تتبؤ أبعاد التتمر

$$
\text { الزواجى بأبعاد الاحتراق النفسى ودرجتها الكلية لدى المرأة. }
$$

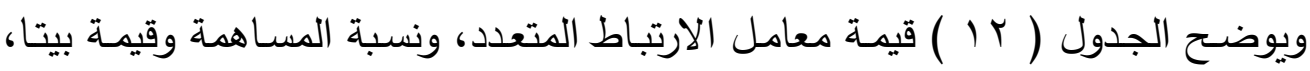

وقيمة (ت)، ودلالتها الإحصائية لكل بعد من أبعاد مقياس الاحتراق النفسى ودرجته الكلية مع

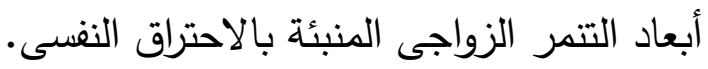

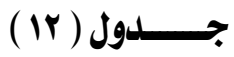

تأثير التنمر الزواجى على الاحتراق النفسى

\begin{tabular}{|c|c|c|c|c|c|c|}
\hline مستوى الدلالة & قيمة & قيمة بيتا & $\begin{array}{c}\text { المساهمة } \\
\text { R2 }\end{array}$ & $\begin{array}{l}\text { الالتعدد R } \\
\text { R }\end{array}$ & | المتفيرات & المتفير \\
\hline \multirow[t]{2}{*}{$\cdot, \cdot 1$} & $v, 99$ & $\cdot, \$ \wedge$ & $\cdot, r \xi$ & $\cdot, \$ \wedge$ & التنمر الانففالى & \multirow{3}{*}{ مؤشرات جسيمة } \\
\hline & & $\wedge, \cdot \bullet$ & & & & \\
\hline \multicolumn{6}{|c|}{ ق Y,Yq = قيمة الثابت العام } & \\
\hline$\cdot, \cdot 1$ & $\wedge, \wedge \mathrm{V}$ & •, Or & $\cdot, \mathrm{YA}$ & •, or & التنمر اللفظى & \multirow{3}{*}{ مؤشرات سلوكية } \\
\hline & $r, 7 r$ & $\cdot$, ro & $\cdot, r \cdot$ & $\cdot, 00$ & التنمر الانفعالى & \\
\hline \multicolumn{6}{|c|}{ قيمة الثبات العاه = Y, Y } & \\
\hline$\cdot,+1$ & 9,14 & $\cdot, 0\}$ & - rq & $\cdot, 0\}$ & التنهمر اللفظى & \multirow{3}{*}{ مؤشرات عاطفية } \\
\hline & $r, 91$ & $\cdot, r Y$ & $\cdot, r I$ & $\cdot, 07$ & الاستيلاء على الممتلكات & \\
\hline \multicolumn{6}{|c|}{ قيمة الثبات العام = \&7, 7} & \\
\hline & $1 \cdot, \$ 0$ & $\cdot, 09$ & $\cdot, \mathrm{r \varepsilon}$ & $\cdot, 09$ & التنهر اللفظى & \multirow{3}{*}{ الدرجة الكلية } \\
\hline$\cdot, \cdot 1$ & r,rr & $\cdot, r \cdot$ & •,rv & $\cdot, 71$ & التنمر الانفعالى & \\
\hline \multicolumn{6}{|c|}{ قيمة الثبات العاه = A A } & \\
\hline
\end{tabular}




\section{يتضح من الجدول السابق ما يلى:}

1- ينبئ التتمر الانفعالى كبعد من ابعاد التتمر الزواجي بالمؤشرات الجسمية كبعد من أبعاد

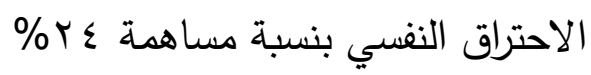

ويمكن صياغة المعادلة التنبؤية الآتية لتوضيح العلاقة العية بين المتغيرات:

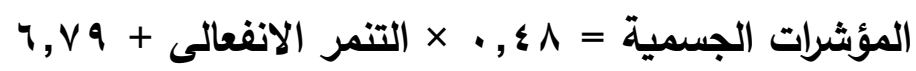

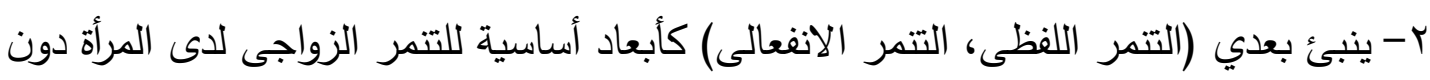

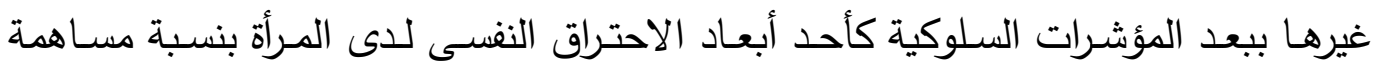

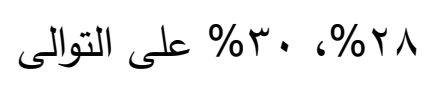

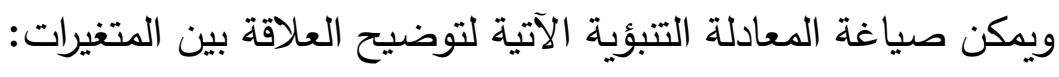

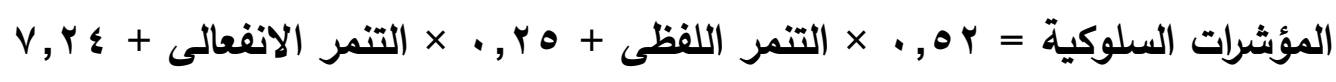

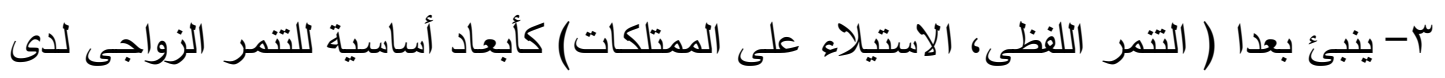

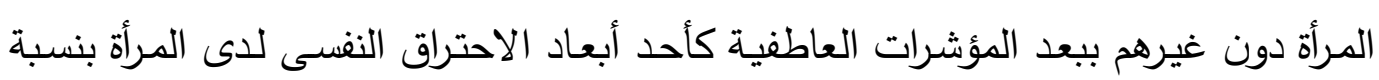

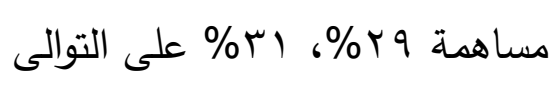

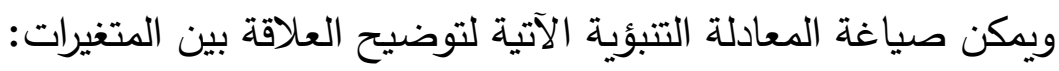

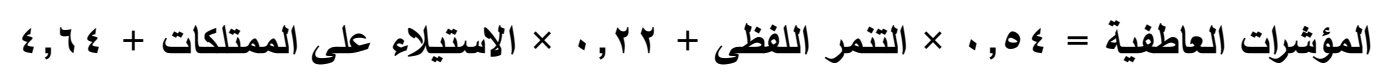

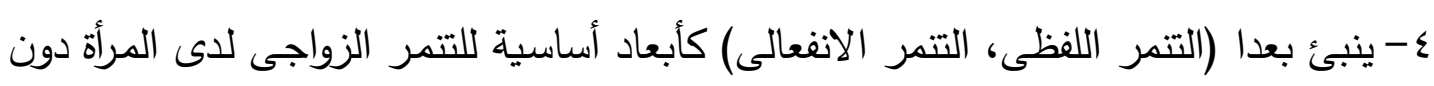

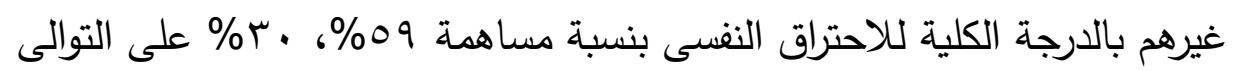

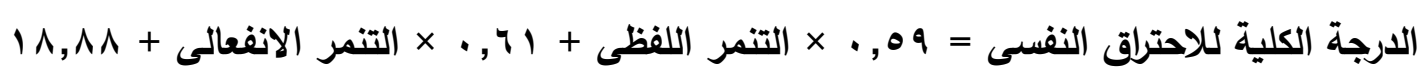

\section{مناقشة نتائج الفرض الثانى: - من}

من خلال عرض النتائج السابقة يتضـح بشكل عام قدرة بعض أبعاد التتمر الزواجى

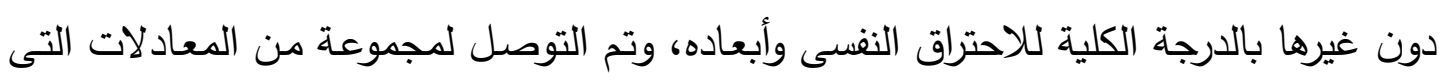

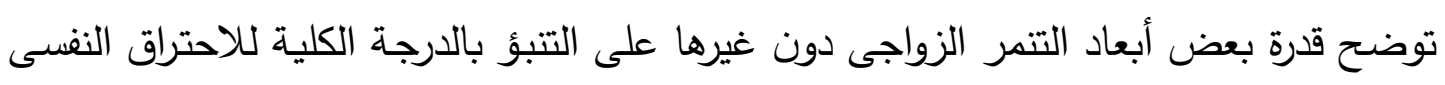
لاى المرأة وأبعاده. فالأسلوب الذى يستخدمه الزوج فى التعبير عن نفسه والتعامل مع زوجته له تأثير كبير

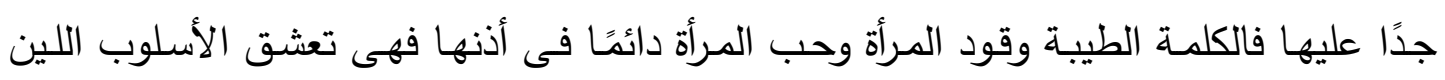
والكلمة التى قبل أن تنطق تتزفق بقلبها. 
والافصاح المتبادل بين الأفراد يؤدى إلى تطور قوى العلاقات، وزيادة العلاقة الحميمية

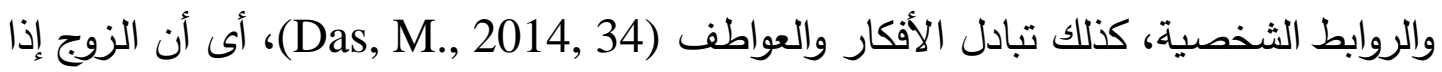

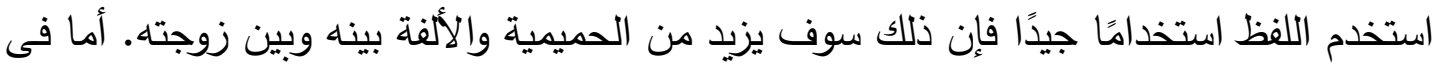
حالة الزوج المتنمر فهو عكس ذلك تمامًا فقد تكون الصفة التى يتتمر على زوجته بها غير

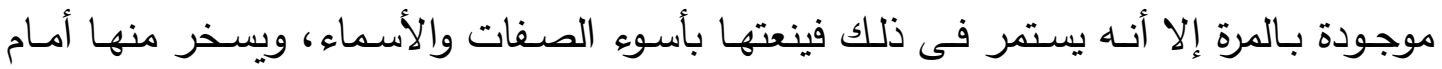
الآخرين سواء أهل، أبناء، أصدقاء محاولًا التقليل من شأنها أو قد يتهكم على شكلها لهاه مدا يكون

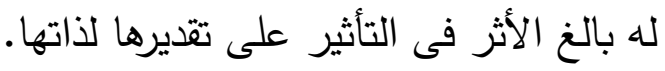

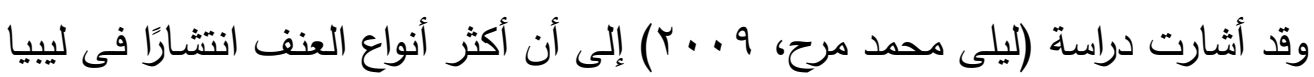
القهر والإيذاء اللفظى، والحرمان من الحقوق. وكذلك التتمر الانفعالى أو العاطفى المتمثل فى الاستهزاء بالزوجة أو تجاهلها، كذلك

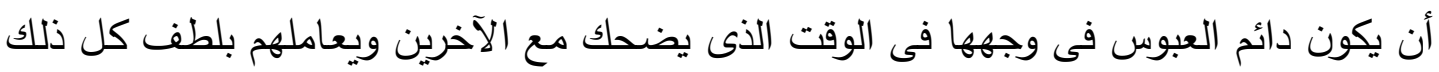

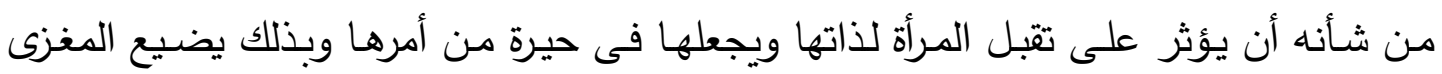

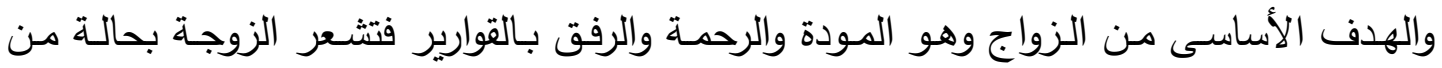

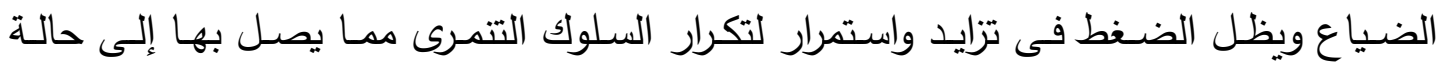
الاحتراق النفسى إذا لم تسرع وتتخذ خطوات علاجية لحل تلك المشكلة. وقد توصلت الباحثة إلى أن هناك بعدان من أبعاد التتمر الزواجى تتبئ بالدرجة الكلية للاحتراق النفسى للمرأة، وهما على الترتيب: 1- التنمر اللفظى: وهو ينبئ بـ (الدرجة الكلية للاحتراق النفسى، المؤشرات العاطفية، المؤشرات السلوكية). ץ- التنمـر الانفعـالى: وهو ينبـئ بـ (الدرجـة الكلية للاحتراق النفسى، المؤشرات السلوكية،

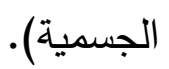
وبالنظر إلى هذين البعدين نلاحظ الآتى:

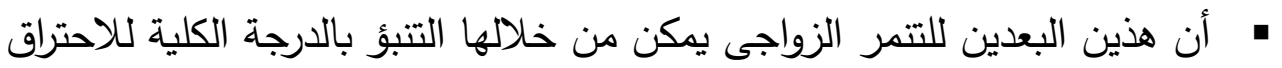

$$
\text { النفسى وجميع أبعاده. }
$$

يشترك التتمر اللفظى، التتمر الانفعالى كأبعاد أساسية للتنمر الزواجى فى التتبؤ

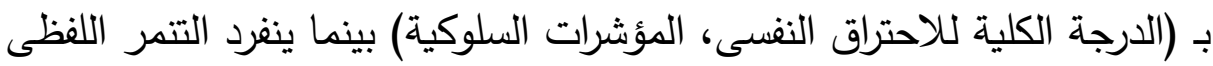


فى التتبؤ بالمؤشـرات العاطفيـة، ينفرد التنمـر الانفعـالى فى التتبؤ بالمؤشـرات الجسمية كأبعاد أساسية للاحتراق النفسى للمرأة.

وبنـاءً على مـا سبق تم التوصل إلى وضـع تصور مقترح يمكن من خلالهـ التتبؤ من بعض أبعاد التتمر الزواجى دون غيرها بالدرجة الكلية للاحتراق النفسى لدى المرأة وأبعادها.

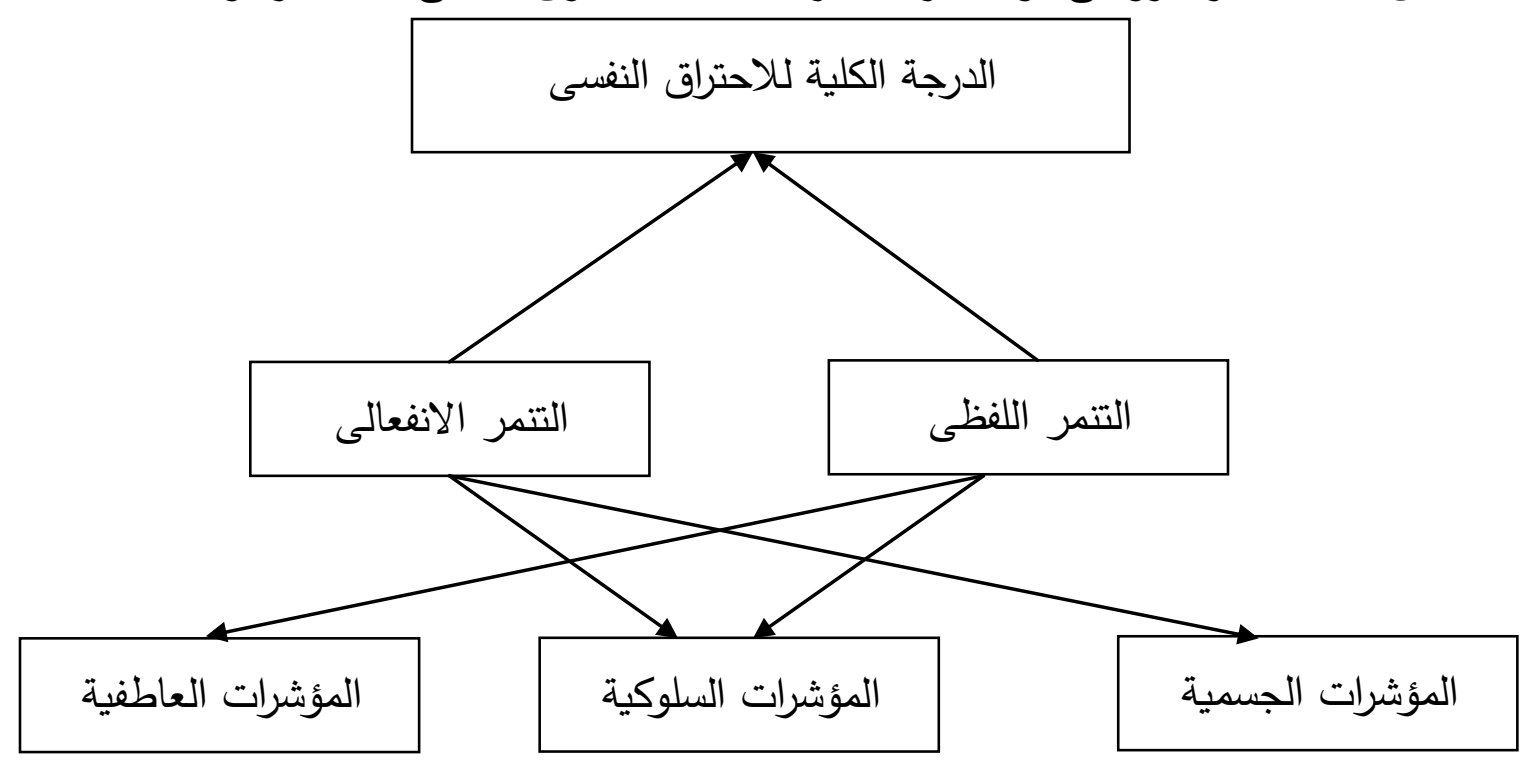

(1) شع (1)

العلاقة التنبؤية بين أبعاد التنمر الزواجى وأبعاد الاحتراق النفسى للى المرأةودرجتها الكلية

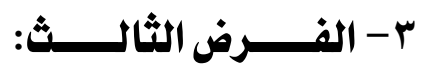

يوجد تأثير دال إحصـائياً لعـاملى (تعمل، لا تعمل) ومدة الزواج ( • ( سنوات فأقل،

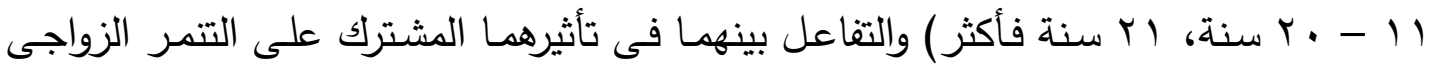
لدى المرأة.

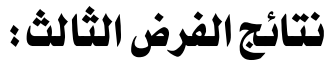

ولاختبار صحة هذا الفرض، تم حساب المتوسطات والانحرافات المعياريـة الجامعة وفقًا

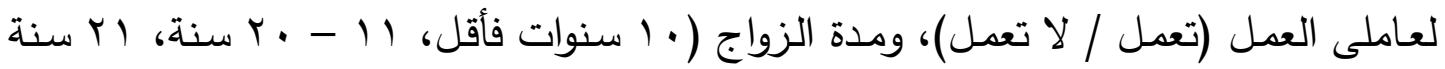
فأكثر) وذلك بالنسبة لأبعاد التتمر الزواجى ودرجتها الكلية، حساب تحليل التباين ثنائى الاتجاه بالنسبة (لعامل العمل، مدة الزواج) والتفاعل بينهما فى تأثيرهما المشترك على التنمر الزواجى. ويوضـح الجدول ( س ا ) البيانـات الوصـفية لعينـة الدراسـة وفقًا لعـاملى العمـل، مـدة الزواج وذلك بالنسبة لأبعاد التمر الزواجى ودرجته الكلية. 


$$
\text { جســدول (ir) }
$$

المتوسط الحسابى والانحراف المعيارى لعينة من السيدات في متفير العمل، ومدة الزواج

\begin{tabular}{|c|c|c|c|c|c|}
\hline الانحراف المعيارى & المتوسط & العدد & ملة الزواج & العمل & أبعاد التنمر \\
\hline$r$ & $0, \gamma$ & T\& & •ا سنوات فأقل & \multirow{4}{*}{ ربات المنزل } & \multirow{12}{*}{ التنهر البدنى } \\
\hline$r, r$ & 0,7 & rr & 11-1 r سنة & & \\
\hline$r, 1$ & $0, Y$ & rq & اب سنة فأكثر & & \\
\hline$r, 1$ & $0, Y$ & 10 & المجموع الكلى & & \\
\hline $1, r$ & $\xi, 7$ & 17 & •ا سنوات فأقل & \multirow{4}{*}{ عاملات } & \\
\hline $1, \wedge$ & $\xi, \wedge$ & 89 & & & \\
\hline $1, Y$ & $\varepsilon, q$ & 0. & اب سنة فأكثر & & \\
\hline $1, Y$ & $\boldsymbol{\varepsilon}, \boldsymbol{\Lambda}$ & Iro & المجموع الكلى & & \\
\hline $1, \wedge$ & $0, \xi$ & 0. & •اسنوات فأقل & \multirow{4}{*}{ العدد الكلى } & \\
\hline$r$ & 0 & Al & & & \\
\hline 1,9 & $0, r$ & Va & اr سنة فأكثر & & \\
\hline 1,9 & 0,1 & rl. & المجموع الكلى & & \\
\hline$r$ & $7, \vee$ & r\& & •ا سنوات فأقل & \multirow{4}{*}{ ربات المنزل } & \multirow{12}{*}{ التنمر اللفظى } \\
\hline$r, r$ & $v, \xi$ & rr & & & \\
\hline$r, r$ & $v, q$ & rq & اب سنة فأكثر & & \\
\hline$r, O$ & $v, r$ & 10 & المجموع الكلى & & \\
\hline$r, \Lambda$ & v & 17 & •ا سنوات فأقل & \multirow{4}{*}{ عاملات } & \\
\hline$r, 1$ & $7, \xi$ & 89 & & & \\
\hline$r, \xi$ & 7,0 & 0. & ا r سنة فأكثر & & \\
\hline$r, r$ & 7,0 & iro & المجموع الكلى & & \\
\hline$r, r$ & 7,1 & 0. & •ا سنوات فأقل & \multirow{4}{*}{ العدد الكلى } & \\
\hline r,r & 7,7 & Al & r-11 & & \\
\hline$r, Y$ & $\checkmark$ & va & ا r سنة فأكثر & & \\
\hline$r, \xi$ & 7,1 & ri. & المجموع الكلى & & \\
\hline
\end{tabular}


التنهر الزواجى وعلاقته بالاحتراقع النفسى لدى المرأة

د/ صفــاء أحمـلـ عجاجــه

\begin{tabular}{|c|c|c|c|c|c|}
\hline الانحراف المعيارى & المتوسط & العدد & مدة الزواج & العمل & أبعاد التنمر \\
\hline$r, r$ & $\vee, \xi$ & 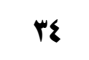 & •اسنوات فأقل & \multirow{4}{*}{ ربات المنزل } & \multirow{12}{*}{ التنمر الانفعالى } \\
\hline$r, \xi$ & $\wedge$ & rr & 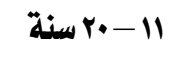 & & \\
\hline$r$ & $\vee, \vee$ & rq & ا r سنة فأكثر & & \\
\hline$r, q$ & $\vee, \vee$ & 10 & المجموع الكلى & & \\
\hline$r$ & $\wedge, 1$ & 17 & •اسنوات فأقل & \multirow{4}{*}{ عاملات } & \\
\hline$r, r$ & $v, r$ & 09 & 11-11 سنة r.-1 & & \\
\hline$r, r$ & $v, 0$ & 0. & ا r سنة فأكثر & & \\
\hline$r, q$ & $v, \xi$ & Iro & المجموع الكلى & & \\
\hline$r, o$ & $v, \eta$ & 0. & •ا سنوات فأقل & \multirow{4}{*}{ العدد الكلى } & \\
\hline$r, r$ & $\checkmark, \xi$ & $\wedge 1$ & 11-11 سنة & & \\
\hline$r, \wedge$ & $\vee, \uparrow$ & va & ا r سنة فأكثر & & \\
\hline$r, q$ & $v, o$ & r. & المجموع الكلى & & \\
\hline$r, 1$ & 0,1 & $r \varepsilon$ & •اسنوات فأقل & \multirow{4}{*}{ ربات المنزل } & \multirow{12}{*}{ الاستيلاء على } \\
\hline$r, r$ & 7 & r & 11-11 بنة & & \\
\hline$r, r$ & 0,7 & rq & ا r سنة فأكثر & & \\
\hline$r, r$ & $0, Y$ & 10 & المجموع الكلى & & \\
\hline r & 0,1 & 17 & •ا سنوات فأقل & \multirow{4}{*}{ عاملات } & \\
\hline 1,9 & $0, \xi$ & 89 & 11-11 بنة & & \\
\hline 1,1 & 0,0 & 0. & ا r سنة فأكثر & & \\
\hline 1,9 & 0,0 & Iro & المجموع الكلى & & \\
\hline r & 0,1 & 0. & •اسنوات فأقل & \multirow{4}{*}{ العدد الكلى } & \\
\hline r & 0,0 & $\wedge 1$ & 11-11 بنة & & \\
\hline 1,9 & 0,0 & va & rا Miأكثر & & \\
\hline r & 0,7 & r. & المجموع الكلى & & \\
\hline$r, 1$ & $7, r$ & $r \xi$ & •اسنوات فأقل & \multirow{4}{*}{ ربات المنزل } & \multirow{4}{*}{ الاجتماعية السيطرة } \\
\hline$r, \wedge$ & 7,0 & r & 11-11 بنة & & \\
\hline$r, r$ & $0, r$ & rq & rl سنة فأكثر & & \\
\hline$r, \xi$ & 7 & 10 & المجموع الكلى & & \\
\hline
\end{tabular}


المدد (r.r.r. أبريل) (r) (r)

مبلة كلية التربية ببنها

\begin{tabular}{|c|c|c|c|c|c|}
\hline الانحراف الميعيارى & المتوسط & العدد & ملة الزواج & العمل المل & أبعاد التنمر \\
\hline$r, \uparrow$ & 7,7 & 17 & •ا سنوات فأكثر & \multirow{4}{*}{ عاملات } & \\
\hline$r, 1$ & 0,1 & $\Delta 9$ & & & \\
\hline$r, r$ & $7, r$ & 0. & ا ا سنة فأكثر & & \\
\hline$r, r$ & 7 & iro & المجموع الكلى & & \\
\hline$r, r$ & $7, ₹$ & 0. & •ا سنوات فأكثر & \multirow{4}{*}{ العدد الكلى } & \\
\hline$r, r$ & 7 & Al & 11--r سنة & & \\
\hline$r, r$ & 0,1 & va & ا ا سنة فأكثر & & \\
\hline$r, r$ & 7 & ri. & المجموع الكلى & & \\
\hline$\wedge, \xi$ & rr & $r \varepsilon$ & •ا سنوات فأقل & \multirow{4}{*}{ ربات منزل } & \multirow{12}{*}{ اللترجة الكلية } \\
\hline $1 \cdot, 1$ & rr,o & rr & 11--11 سنة & & \\
\hline $1 \cdot, r$ & rr,II & rq & ا ا سنة فأكثر & & \\
\hline 9,7 & $r r, \xi$ & 10 & المجموع الكلى & & \\
\hline $1 \cdot, 0$ & $r r, l$ & 17 & •اسنوات فأقل & \multirow{4}{*}{ عاملات } & \\
\hline$\wedge, r$ & $r q, 0$ & 89 & 11--r. سنة & & \\
\hline 9,0 & $r \cdot, 0$ & 0. & ا r سنة فأكثر & & \\
\hline 9,1 & $r \cdot, r$ & iro & المجموع الكلى & & \\
\hline 9 & rr & 0. & •اسنوات فأقل & \multirow{4}{*}{ العدد الكلى } & \\
\hline $9, r$ & $r \cdot, r$ & $\wedge 1$ & & & \\
\hline $9, Y$ & ri,l & va & ا ا سنة فأكثر & & \\
\hline $9, r$ & HI,I & r. & المجموع الكلى & & \\
\hline
\end{tabular}

ويوضـح الجدول ( ؟1 ) تحليل التباين ثنائى الاتجاه (Y × r r) لمتغيرى العمل ومدة الزواج والتفاعل بينهما فى تأثيرهما المشترك على التتمر الزواجى لدى المرأة. 


\section{جلدول ( 1 )}

\section{نتائج تحليل التباين ثنائى الاتجاه ( × × Y ) لتفاعل المرأة،}

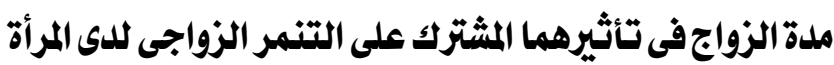

\begin{tabular}{|c|c|c|c|c|c|c|}
\hline مستوى الدلالة & قيمة F & $\begin{array}{c}\text { متوسط المربعات } \\
\text { Mean Square }\end{array}$ & درجة الحرية & مجموع المربعات & مصدر التباين & الأبعاد \\
\hline$\bullet,+1$ & & ra, $7 r$ & 1 & rq, רr & العمل (أ) & \multirow{5}{*}{ التنمر البلى } \\
\hline غير دالة & $* * \| 11, \mathrm{rr}$ & •, rr & r & $\bullet, \sum V$ & ملة الزواج (ب) & \\
\hline غير دالة & $\cdot, \cdot v$ & 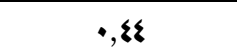 & $r$ & $\cdot, \wedge \wedge$ & تقاعل أ × ب & \\
\hline \multirow[t]{2}{*}{ غير دالة } & $\cdot$, ir & r,or & $r \cdot \varepsilon$ & $V r \cdot, \Delta 0$ & تباين الخطأ & \\
\hline & & & M. & 7rra,... & المجموع & \\
\hline غير دالة & r,ov & $r \cdot, \cdot 9$ & 1 & $r \cdot, \cdot q$ & العمل (أ) & \multirow{5}{*}{ التنمر التظى } \\
\hline غير دالة & $\cdot, \sum r$ & $r, \& r$ & $r$ & $\xi, \wedge \xi$ & ملة الزواج (ب) & \\
\hline غير دالة & $1,0 \wedge \Lambda$ & 1,90 & $r$ & iv, q. & تفاعل أ × ب & \\
\hline \multirow[t]{2}{*}{ غير دالة } & $1,0 \wedge \Lambda$ & $0,7 r$ & $r \cdot \varepsilon$ & $11 \leqslant 9, r v r$ & تباين الخطأ & \\
\hline & & & rl. & $M r \cdot r, \wedge r q$ & المجموع & \\
\hline غير دالة & $\cdot, \cdot 9$ & $\cdot, 70$ & 1 & $\cdot, 70$ & العمل (أ) & \multirow{5}{*}{ الانفقالى التنمر } \\
\hline غير دالة & $\cdot, \cdot 7$ & $\cdot, 81$ & $r$ & - Ar & ملة الزواج (ب) & \\
\hline \multirow[t]{3}{*}{ غير دالة } & $\cdot, 90$ & $7, r q$ & $r$ & Ir, Vr & تقاعل أ × ب & \\
\hline & & $\eta, r$. & $r \cdot \varepsilon$ & Iry7, & تباين الخطأ & \\
\hline & & & rl. & IrrAo,... & المجموع & \\
\hline غير دالة & 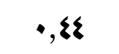 & $1, v 7$ & 1 & $1, v 9$ & العمل (أ) & \multirow{5}{*}{ الاستيلاء } \\
\hline غير دالة & $\cdot, r \Lambda$ & 1,14 & $r$ & $r, r q$ & ملة الزواج (ب) & \\
\hline \multirow[t]{3}{*}{ غير دالة } & •, ro & $1, \xi$ & r & $r, \wedge \cdot$ & تفاعل أ × ب & \\
\hline & & $\xi$ & $r \cdot \varepsilon$ & $A 1 \varepsilon, 99$ & تباين الخطأ & \\
\hline & & & r. & Vror,... & المجموع & \\
\hline غير دالة & $\cdot$, IV & $\cdot, \wedge \mathrm{V}$ & 1 & $\cdot, \wedge V$ & العمل (أ) & \multirow{5}{*}{ الاحتماعرة } \\
\hline غير دالة & $1, \$ 0$ & $v, r v$ & $r$ & $1 \&, Y 0$ & ملة الزواج (ب) & \\
\hline \multirow[t]{3}{*}{ غير دالة } & $r, r q$ & $11, v$. & $r$ & $r r, \$ 1$ & تقاعل أ × ب & \\
\hline & & 0,11 & $r \cdot \xi$ & $1 \cdot \xi 1, \xi r$ & تباين الخطأ & \\
\hline & & & r. & $1790, \cdots$ & المجموع & \\
\hline غير دالة & $1,7 \varepsilon$ & $\mid \xi T, r \wedge$ & 1 & IEr, rA & العمل (أ) & \multirow{5}{*}{ اللالترجة الكلية } \\
\hline غير دالة & $\cdot, \cdot 1$ & $v, \cdot r$ & $r$ & $1 \varepsilon, \cdot v$ & ملة الزواج (ب) & \\
\hline \multirow[t]{3}{*}{ غير دالة } & $\cdot, 70$ & $0 Y, \vee q$ & r & $\| 1 r, \Delta \Lambda$ & تفاعل أ × ب & \\
\hline & & AV, rq & $r \cdot \varepsilon$ & $I V \Lambda \cdot V, r \varepsilon$ & تباين الخطأ & \\
\hline & & & r. & rrITEA,... & المجموع & \\
\hline
\end{tabular}




\section{ويوضح الجدول ( ؛ 1 ) ما يلى:}

1- توجد فروق ذات دلالة إحصائية بين (السيدات العاملات، غير العاملات "ربات البيوت" )

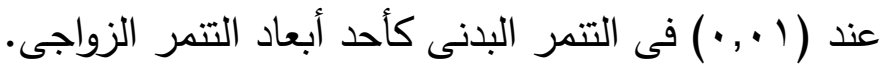

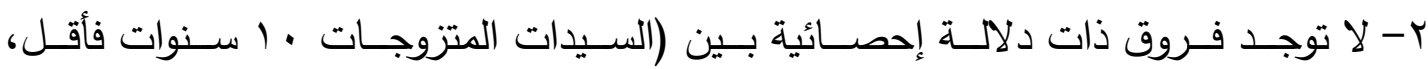

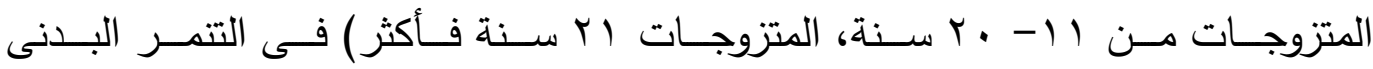

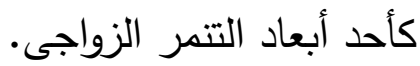

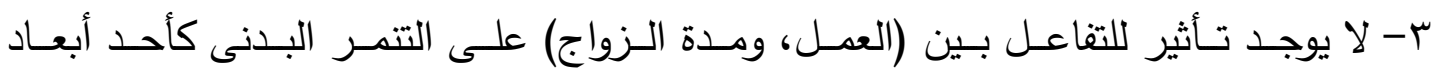
التنمر الزواجى. ع - لا توجد فروق ذات دالة بين (السيدات العاملات، غير العاملات "ربات البيوت") وكذلك فى

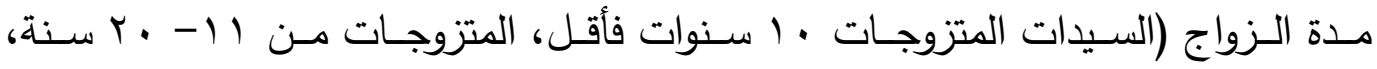
المتزوجات (Y سنة فأكثر) والتفاعل بينهما فى تأثيرهما المشترك على التتمر اللفظى كأحد

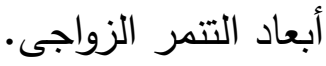
ه- لا توجد فروق دالة بين السيدات العاملات، غير العاملات "ربات البيوت") وكذلك فى مدة الزواج (السيدات المتزوجات • (1 سنوات فأقل، المتزوجات من 11- ـ ب سنة، المتزوجات

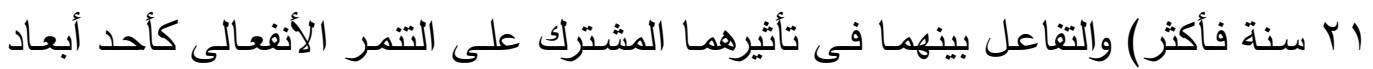

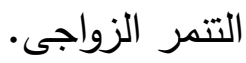
7- لا توجد فروق دالة بين السيدات العاملات، غير العاملات "ربات البيوت") وكذللك فى مدة

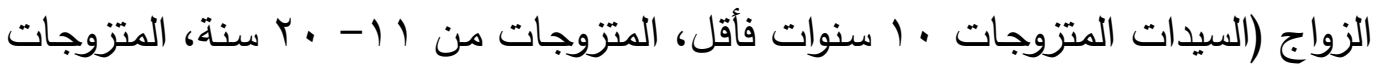

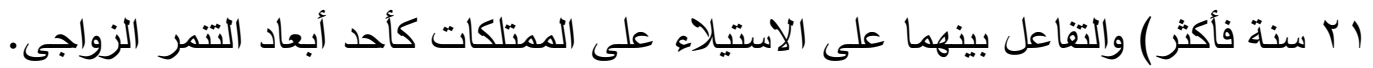
V- لا توجد فروق دالة بين السيدات العاملات، غير العاملات "ربات البيوت") وكذلك فى مدة

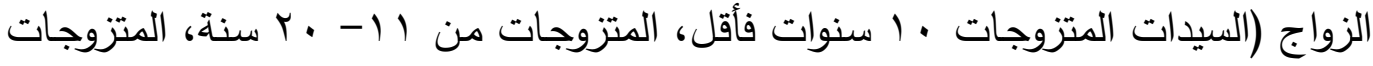

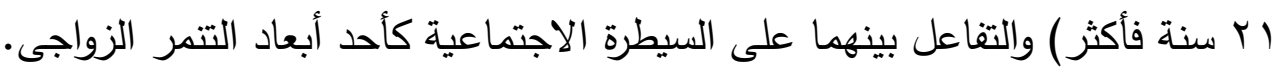
1- لا توجد فروق دالة بين السيدات العاملات، غير العاملات "ربات البيوت") وكذلك فى مدة

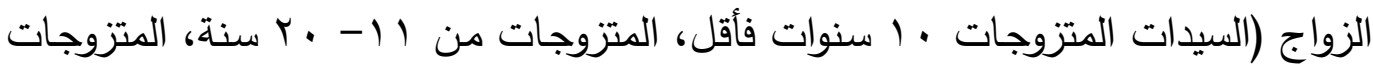

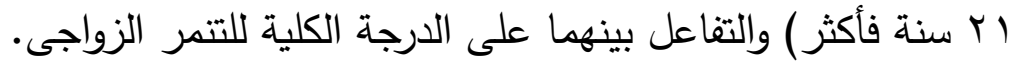




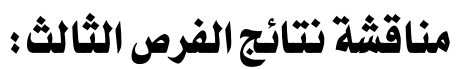

توصلت النتائج بشكل عام إلى عدم وجود فروق ذات دلالة إحصائية بين (السيدات العاملات، وغير العاملات "ربات البيوت") فى الدرجة الكلية للتنمر الزواجى. ويمكن تفسير ذلك بأن الزوج المتنمر سواء رجع سبب تتمره إلى أسـاليب التنشئة الخاطئة أو أسلوب متعدد أو كميكانيزم دفاعى اسقاطى على الحلقة الأضعف فى حياته فكل ما يهمه الوصول إلى حالة من الارتياح سواء كانت زوجته عاملة أو ربة منزل فهو شخص أنانى أو لكى يثعر نفسه بالقوة والزهو.

وقد أشـار (Kalaca \& Dundar, 2010) فى دراسـة قامـا بإجرائها على 110

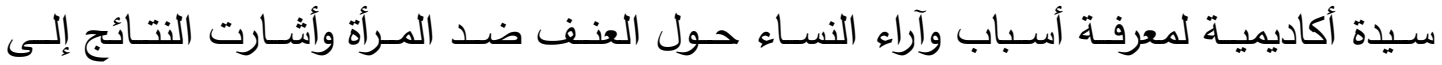

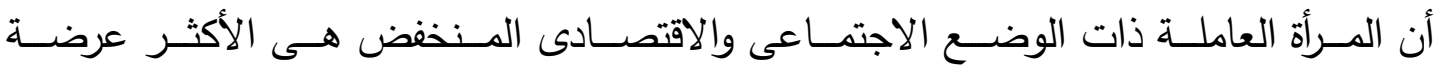

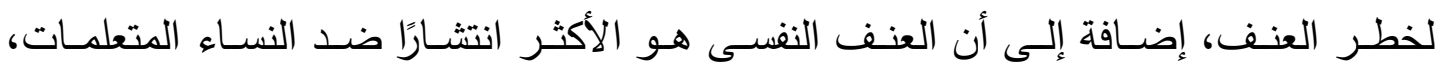

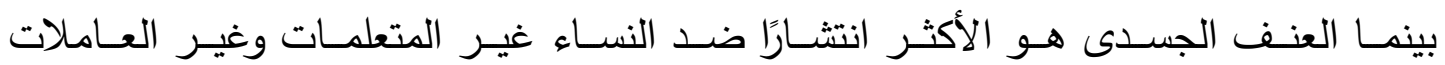

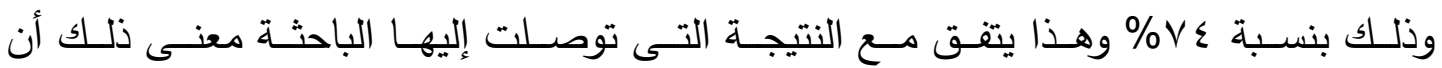

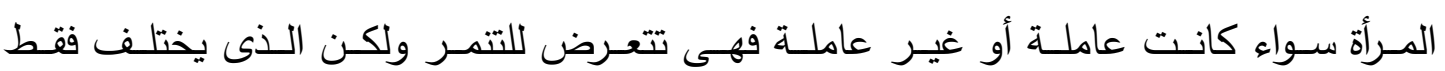
نوع التنمر الذى تعرضت له. وتثير النتائج أيضًا إلى عدم وجود فروق بين السيدات (المتزوجات ـاسنين فأقل، المتزوجات من (1 - • ب سنة، (Y سنة فأكثر) فى الدرجة الكلية للتنمر الزواجى. ويمكن تفسير ذلك بأنه وإن دل على عدم النضـج العقلى والعاطفى للزوج فإنه يدل أيضًا على افتقاد أو افتقار المرأة للذكاء العاطفى فمن المتوقع أنه مع امتداد العشرة بين الزوجين

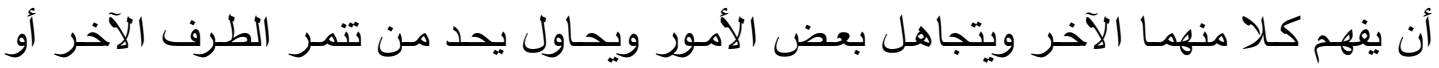
يساعده على التعبير بأسلوب أفضل. وكذلك أشارت النتائج إلى وجود فروق ذات دلالة إحصائية بين (السيدات العاملات، غير العاملات "ربات البيوت") عند ا .,. فى التتمر البدنى كأحد أبعاد التتمر الزواجى. 
ويمكن تفسير ذلك بأن تعرض المرأة غير العاملة (ربة المنزل) إلى التتمر البدنى قد يرجع إلى:

الرجل نفسـه قد يلجأ إلى أسقاط مـا بداخلـه من احباطـات نتيجة العهل على زوجته باعتبارها العنصر الأضعف وأنه هو رب المنزل الذى يبذل الجهد ويخرج للعمل أما هى

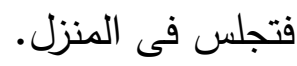
ومما قد يزيد من الأمر طريقة تلقى المرأة التى لا تعمل لذلك السلوك بنوع من عدم الحكمة والسكوت مما يؤدى إلى زيادة استخدام الزوج للتنمر البدنى وتتخذ المرأة دور الضحية. أما فى حالة المرأة العاملة فى كثير من الأحيان لا يقدر على ذلك فالطرفان متساويان يخرجان للعمل ويتثاركان اقتصادياً مما يحدث نوعًا من القوى المتوازنة التى تجبره على عدم

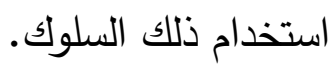

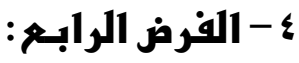

يوجد تأثير دال إحصائياً لعاملى العمل (تعمل، لاتعمل) ومدة الزواج (• ( سنوات فأقل،

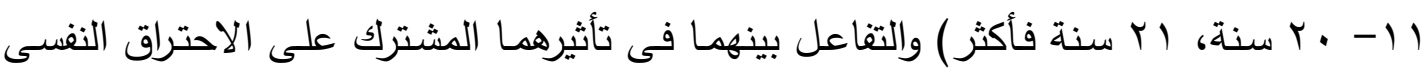

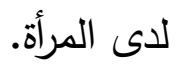

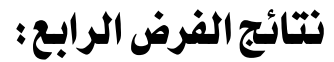

ولاختبـار صــحة هــا الفـرض، تـم حسـاب المتوسـطات والانحرافـات المعياريــة

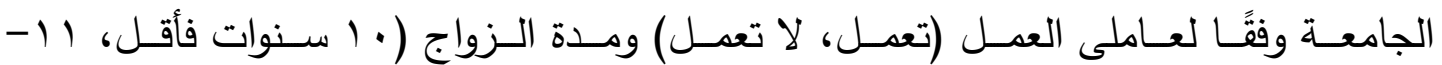

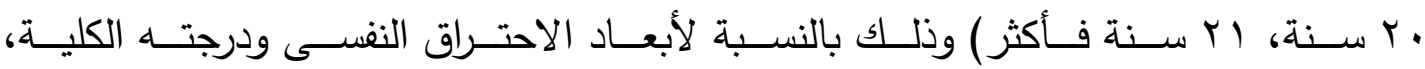
حسـاب تحليـل التبـاين ثــائى الاتجــاه بالنسـبة (لعـاملى العهـل، مـــة الـزواج) والتفاعـلـ بينهما فى تأثيرهما المشترك على الاحتراق النفسى. ويوضـح الجدول ( 10 ) البيانـات الوصـفية لعينـة الدراسـة وفقًَا لعـاملى العدل، مدة الزواج وذلك بالنسبة لأبعاد الاحتراق النفسى ودرجته الكلية. 


$$
\text { جـــــ (10) }
$$

المتوسط الحسابى والانحراف المعيارى لعينة من السيدات فى متفير العمل، وملدة الزواج

\begin{tabular}{|c|c|c|c|c|c|}
\hline الانحراف المعيارى & المتوسط & 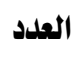 & ملدة الزواج & العمل & أبعاد الاحتراق النفسى \\
\hline$r, Y$ & $|\cdot, Y|$ & $r \varepsilon$ & •ا سنوات فأقل & \multirow{4}{*}{ ربات المنزل } & \multirow{24}{*}{ مؤشرات جسمية } \\
\hline$r, r$ & $11,1 \varepsilon$ & rr & |l-r-r سنة & & \\
\hline$r, o$ & $11,1 \varepsilon$ & rq & اY سنة فأكثر & & \\
\hline$r, o$ & $1 \cdot, \sqrt{ } 7$ & 10 & المجموع الكلى & & \\
\hline$r, Y$ & 9,07 & 17 & •ا سنوات فأقل & \multirow{4}{*}{ ع علات } & \\
\hline$r, r$ & 9,77 & 89 & r-11 & & \\
\hline$r, Y$ & $1 \cdot,\{\Lambda$ & 0. & اب سنة فأكثر & & \\
\hline 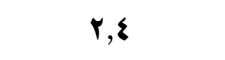 & $9,9 V$ & Iro & المجموع الكلى & & \\
\hline$r, \eta$ & 1. & o. & •ا سنوات فأقل & \multirow{4}{*}{ العلد الكلى } & \\
\hline$r, r$ & $1 \cdot,+9$ & $\wedge 1$ & r-11 & & \\
\hline$r, \eta$ & $1 \cdot, Y r$ & va & اr سنة فأكثر & & \\
\hline$r, o$ & $1 \cdot, r \cdot$ & m. & المجموع الكلى & & \\
\hline$r, Y$ & ir, IV & $r \varepsilon$ & •ا سنوات فأقل & \multirow{4}{*}{ ربات منزل } & \\
\hline$r, 1$ & $\mathbb{1 r}, 0_{0}$ & rr & 11--11 سنة & & \\
\hline$r, r$ & $|r, \Sigma|$ & rq & اب سنة فأكثر & & \\
\hline$r, r$ & Ir,rr & 10 & المجموع الكلى & & \\
\hline$r, \xi$ & Ir, ro & 17 & •ا سنوات فأقل & \multirow{4}{*}{ 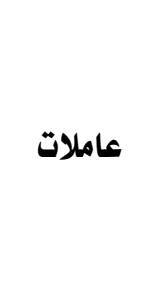 } & \\
\hline$r, r$ & $11, \cdot r$ & $\Delta q$ & r-11-11 & & \\
\hline$r, 7$ & ir & 0. & ا سنة فاكثثر & & \\
\hline$r$ & $I I, O V$ & iro & المجموع الكلى & & \\
\hline$r, q$ & Ir,Y. & 0. & •ا سنوات فأقل & \multirow{4}{*}{ العدد الكلى } & \\
\hline$r, r$ & 11,81 & Al & |l-r-r سنة & & \\
\hline$r, 1$ & 17,10 & va & اY سنة فأكثر & & \\
\hline$r, \Lambda$ & $\|, \wedge \Lambda$ & r. & المجموع & & \\
\hline
\end{tabular}


مجلة كلية التربية ببنها

\begin{tabular}{|c|c|c|c|c|c|}
\hline الانحراف الميميارى & المتوسط & 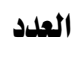 & ملدة الزواج & 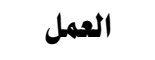 & أبعاد الاحتراق النفسى \\
\hline$r, Y$ & $9,9 \varepsilon$ & rร & •ا سنوات فأقل & \multirow{4}{*}{ بات منزل } & \multirow{24}{*}{ مؤشرات عاطفية } \\
\hline$r, r$ & $9,7 \xi$ & rr & |l--بr سنة & & \\
\hline$r, 0$ & $9,7 r$ & rq & ا ا سنة فأكثر & & \\
\hline Y, & $9, Y 0$ & 10 & المجموع الكلى & & \\
\hline$r, r$ & $9, \wedge \wedge$ & 17 & •ا سنوات فأقل & \multirow{4}{*}{ 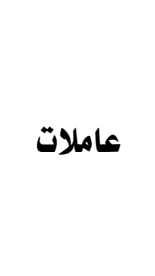 } & \\
\hline$r, \Lambda$ & $\wedge, 7 \wedge$ & 89 & 11--r سنة & & \\
\hline$r, q$ & 9 & 0. & ا ابنة فأكثر & & \\
\hline$r, q$ & $9, \cdot 0$ & iro & المجموع الكلى & & \\
\hline$r, \wedge$ & 9,94 & o. & •ا سنوات فأقل & \multirow{4}{*}{ العدد الكلى } & \\
\hline$r, Y$ & $9, \cdot v$ & Al & 11--r سنة & & \\
\hline$r, r$ & $9, r \mu$ & va & ا ابنة سأكثر & & \\
\hline$r, r$ & Q,rr & rl. & المجموع الكلى & & \\
\hline$\eta, r$ & rr, rr & $r \varepsilon$ & •ا سنوات فأقل & \multirow{4}{*}{ بـات منزل } & \\
\hline $0, r$ & rr, rr & $r r$ & 11--11 سنة & & \\
\hline $0, \xi$ & rr, IV & rq & ا ا سنة فأكثر & & \\
\hline $0, Y$ & rr, ^₹ & ^o & المجموع الكلى & & \\
\hline$\wedge, r$ & rI, 79 & 17 & •ا سنوات فأقل & \multirow{4}{*}{ عاملات } & \\
\hline 7 & $r q, 0\}$ & $\Delta q$ & 11--11 سنة & & \\
\hline$\wedge, r$ & 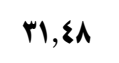 & 0. & ا ا سنة فأكثر & & \\
\hline$v, r$ & $r \cdot, 09$ & iro & المجموع الكلى & & \\
\hline 7,9 & rr, & 0. & •ا سنوات فأقل & \multirow{4}{*}{ العلد الكلى } & \\
\hline 7 & $r \cdot, \$ 0$ & Al & 11--11 سنة & & \\
\hline$v, \xi$ & rr,l. & va & ا ا سنة فأكثر & & \\
\hline $7, \Lambda$ & Mi,o. & rI. & المجموع & & \\
\hline
\end{tabular}

ويوضـح الجدول ( 1 ) ) تحليل التباين ثنائى (Y × r ) لمتغيرى العمل ومدة الزواج

والتفاعل بينها فى تأثيرهما المشترك على الاحتراق النفسى لدى المرأة. 


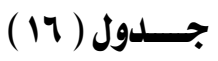

نتائج تحليل التباين ثنائى الاتجاه ( × × r ) لتفاعل العمل،

ملدة الزواج فى تأثيرهما المشترك على الاحتراق النفسى للدى المرأة

\begin{tabular}{|c|c|c|c|c|c|c|}
\hline مستوى الدلالة & قيمة F F & متوسط المربعات & درجة الحرية & مجموع المربعات & مصلدر التباين & الأبعاد \\
\hline$\cdot, \cdot 0$ & $* \eta, r r$ & rq,ar & 1 & rq,ar & العمل (أ) & \multirow{5}{*}{ المؤشرات } \\
\hline غير دالة & 1,91 & $I 1, r v$ & $r$ & $r r, \Delta 0$ & ملة الزواج (ب) & \\
\hline \multirow[t]{3}{*}{ غير دالة } & $\cdot, 09$ & r,o. & $r$ & $v, 1$ & تقاعل أ × ب & \\
\hline & & 0,94 & $r \cdot \xi$ & $\mid r \cdot q, Y \xi$ & تباين الخطأ & \\
\hline & & & r. & rrorA & المجموع & \\
\hline غير دالة & $1,9 v$ & $10,1 \varepsilon$ & 1 & 10,18 & العمل (أ) & \multirow{5}{*}{ المؤشرات } \\
\hline غير دالة & $\cdot, 7$. & $\xi, 7 \xi$ & $r$ & $9, \mathrm{rA}$ & ملة الزواج (ب) & \\
\hline \multirow[t]{3}{*}{ غير دالة } & $1, \bullet \wedge$ & A,rr & $r$ & 17,79 & تفاعل أ × ب & \\
\hline & & $v, v \cdot$ & $r \cdot \varepsilon$ & $10 V, \$ 1$ & تباين الخطأ & \\
\hline & & & r. & riroy & المجموع & \\
\hline غير دالة & $1, r 9$ & $1 ., 19$ & 1 & $1 ., 19$ & العمل (أ) & \multirow{5}{*}{ المأشرات الماطفية } \\
\hline غير دالة & $\cdot, 19$ & Y,Or & r & $17, \cdot 7$ & ملة الزواج (ب) & \\
\hline \multirow[t]{3}{*}{ غير دالة } & $\cdot, r r$ & $1, n 1$ & r & $r, \xi Y$ & تفاعل أ × ب & \\
\hline & & V,rr & $r \cdot \xi$ & $1 \leqslant 9 \&, \leqslant V$ & تباين الخطأ & \\
\hline & & & r. & 19AYA & المجموع & \\
\hline$\cdot, \cdot 0$ & $r, \wedge \uparrow$ & IVT,IA & 1 & IVr,IA & العمل (أ) & \multirow{5}{*}{ للدرجة الكلية } \\
\hline غيردالة & $\cdot, r \varepsilon$ & $10, r q$ & $r$ & $r \cdot, v \wedge$ & ملة الزواج (ب) & \\
\hline \multirow[t]{3}{*}{ غير دالة } & $\cdot, \mathrm{V}$ & $r r, r v$ & $r$ & 77, or & تفاعل أ × ب & \\
\hline & & $\llbracket \xi, \wedge \Lambda$ & $r \cdot \varepsilon$ & 9107 & تباين الخطأ & \\
\hline & & & r. & rivanA & المجموع & \\
\hline
\end{tabular}

$$
\text { ويوضح الجدول ما يلى: }
$$

1-توجد فروق ذات دلالة إحصائية بين السيدات العاملات، غير العاملات (ربات البيوت) عند

$$
\text { (0. . . • ) فى المؤشرات الجسمية كأحد أبعاد الاحتراق النفسى. }
$$

ץ- لا توجد فروق ذات دلالة إحصائية بين (السيدات المتزوجات · ا سنوات فأقل، المتزوجات

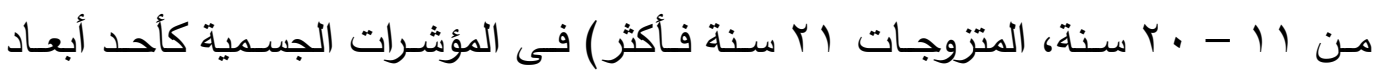


ب- لا يوجد تأثير للتفاعل بين (العهل، ومدة الزواج) على المؤشرات الجسمية كأحد أبعاد

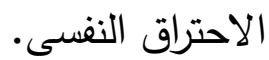
ع - لا توجد فروق دالة بين (السيدات العاملات، غير العاملات "ربات البيوت") وكذلك فى مدة

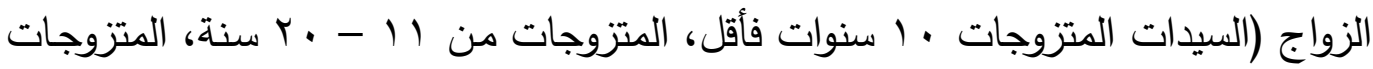

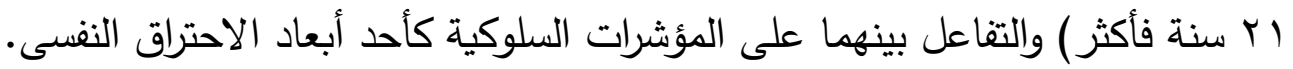

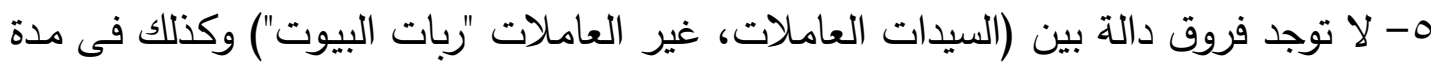
الزواج (السيدات المتزوجات • ( سنوات فأقل، المتزوجات من ل| 1 - • ب سنة، المتزوجات اب سنة فأكثر) والتفاعل بينهما على المؤشرات العاطفية كأحد أبعاد الاحتراق النفسى.

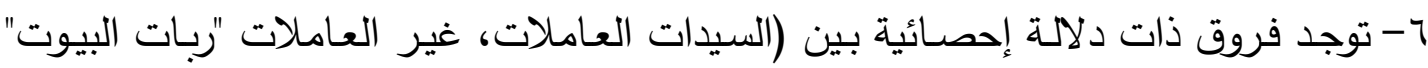
عند (0. . •) فى الدرجة الكلية للاحتراق النفسى.

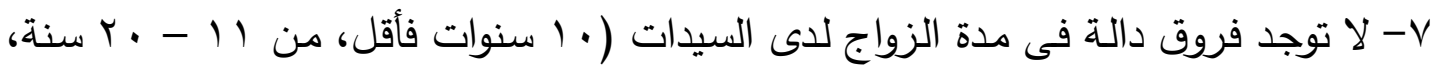

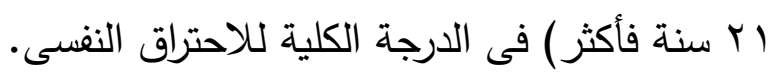

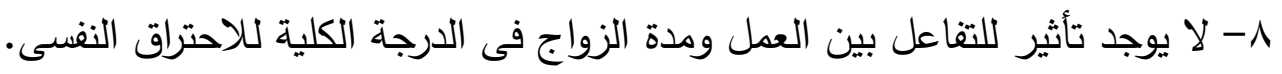

\section{مناقشة نتائج الفرض الرابع: - من}

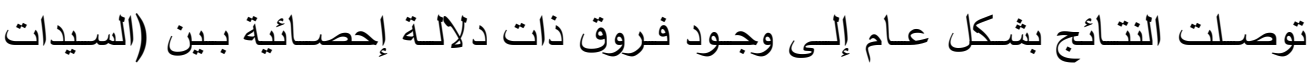
العاملات، غير العاملات "ربات البيوت") فى الدرجة الكلية للاحتراق النفسى.

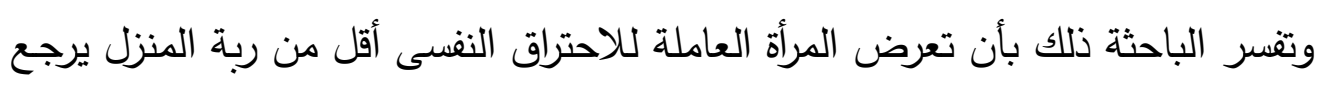

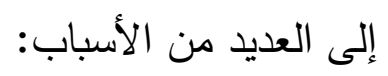

فبخروج المرأة للعمل تكتسب وضع ومكانة اجتماعية، وكذلك استقلال مادى مما يشعرها

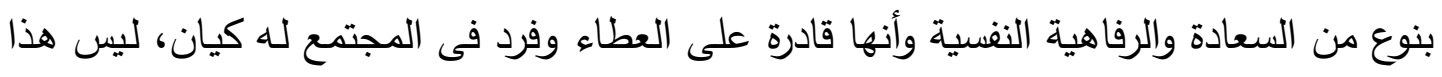

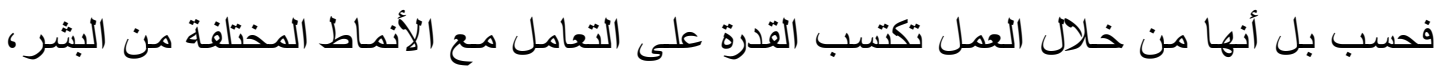

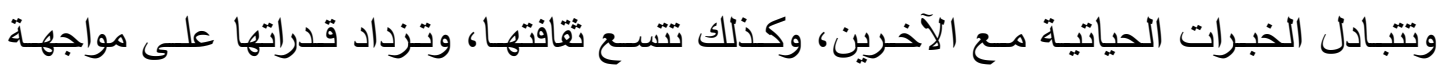

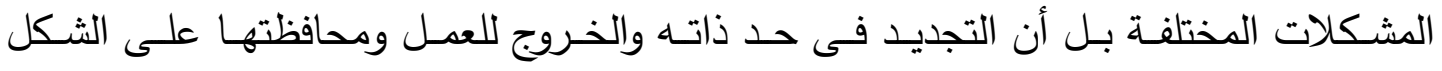
الاجتماعى من خلال إرتداء الملابس اللائقة والحفاظ على مظهرها يكسب المرأة فى حد ذاته واته

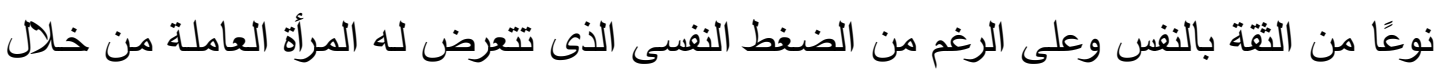

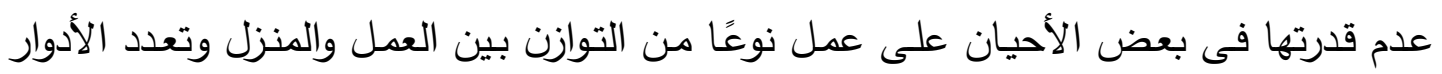


التى تقع على عائقها إلا أن المميزات التى تكتسبها من خلال خروجها للعمل قد تهون عليها الكثير وقد ينعكس أيضًا عليها بعمل نوع من التنظيم والادارة للمنزل وللأفراد أيضًا.

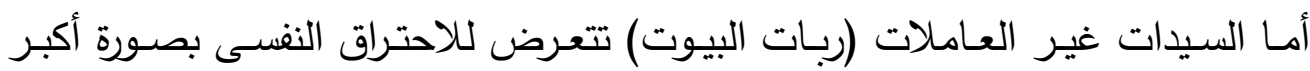

$$
\text { للعديد من الأسباب منها: }
$$

نمطيـة الحيـاة التى تعيثـها ربـة المنزل والـروتين اليومى المتكرر، ، عدم اختلاطهـا

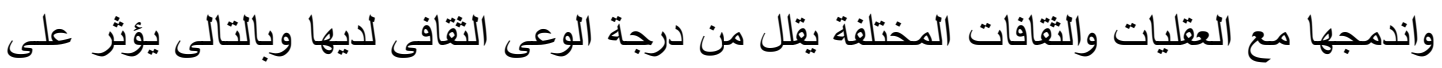
اكتسابها للعديد من المهارات فى الإدارة والتتظيم ومواجهة الأزمات.

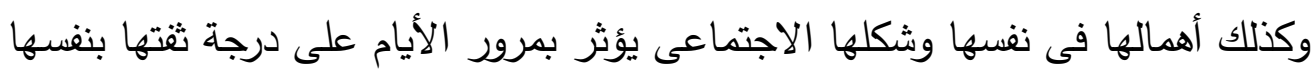
ويشعرها بأنها أقل من الآخرين.

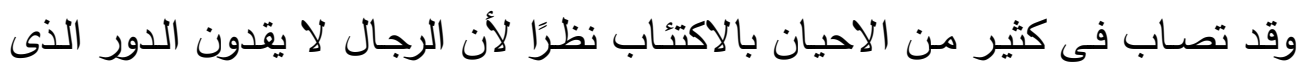

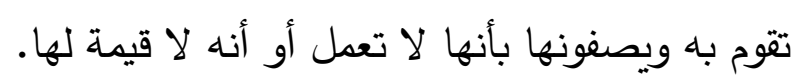

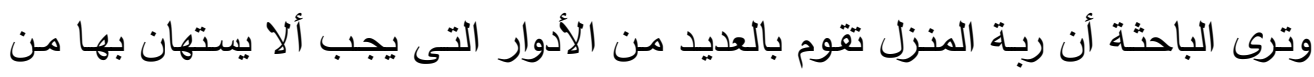

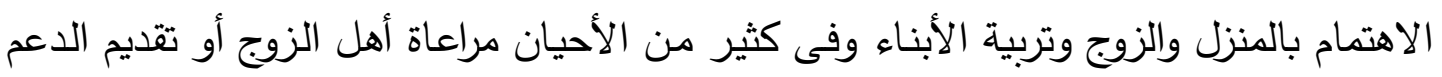

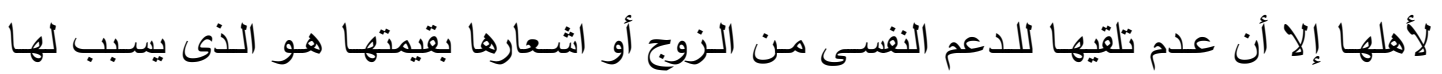
الاحباط، ويرفع من مستوى الاحتراق النفسى لديها.

\section{ثانياً: نتائج الدراسة الكلينكية:}

ينص الفرض على: هل تختلف الديناميات النفسية لمرتفعى الاحتراق النفسى والتعرض للتنمر الزواجى.

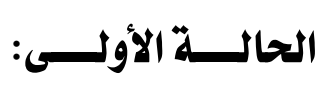

1- البيانات الأولية للحالة:

$$
\begin{aligned}
& \text { الاسم: أ. س. ع الاولية لجالة } \\
& \text { العمر الزمنى: الادم: اله ع }
\end{aligned}
$$

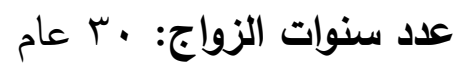

المهنة: لا تعمل علدوات الرواج

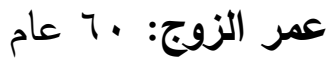

مهنته: معاش بالجيش المري

المستوى الاجتماعى: متوسط يالئ

المستوى الاقتصادى: مرتفع الاجتماعي: متوسط 
r- ملخص الحالة من خلال استمارة المقابلة الثخصية والملاحظة الكلينكية المباشرة وغير

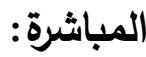

تركيبـة الأسـرة: تتكون أسـرة الحالـة الصغيرة من ه أشخاص أب، أم، وبنتان وولد، الكبرى متزوجة، الثانية مخطوبة، والولد فى المرحلة الثانوية. الحالـة السكنية: كانت الأسرة تعيش فى بيت العيلة وانتقلت منذ ه سنوات إلى بيت جديد حديث. تاريخها الأسرى: تاريخ الحالة الأسرى غير سار فكان والدها رغم طيبته إلا أنه من

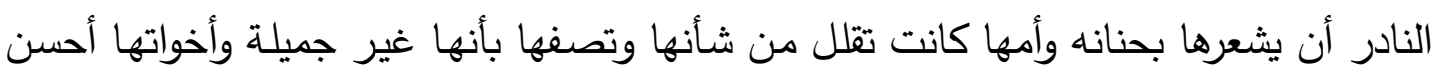
منها شكلًا وهذا خلق فجوة بين الحالة وأسرتها.

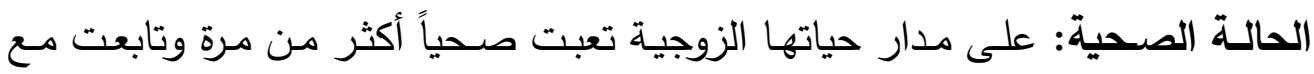

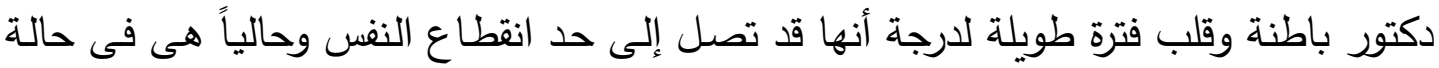

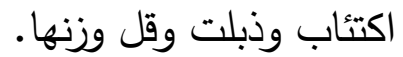
علاقاتها الاجتماعيـة: علاقتها بالأصدقاء والجيران جيدة أما علاقتها مـع أهل الزوج

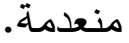
أسباب المشكلات من وجهة نظرها: ترى الحالة أن زوجها سبب كل المشاكل بسبب الوسواس القهرى الذى لديه وشخصيته النرجسية المتعالية حيث يرى أنه أفضل من الجميع وأنه

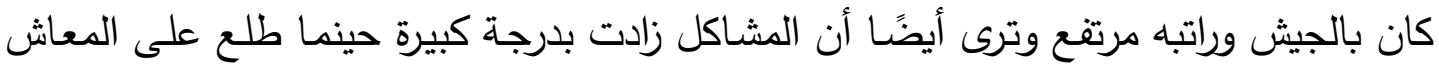

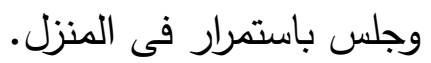
كيفية مواجهة الأزمات الزواجية: كانت الحالة فى بداية حياتها الزوجية تلتزم الصمت فئرات وتخاف من زوجها أما الآن فقد تغيرت كثيرًا وأصبحت ترد عليه الآساءة بالاساءة وحياتها الآن شبه مستحيلة. نمط حياتها وكيف تدير وقتها: الحالة نمط حياتها سيء وغير منظم فهى تتام طوال

$$
\begin{aligned}
& \text { النهار وتسهر طوال الليل حتى لا ترى زوجها. } \\
& \text { الهوايات: لا يوجد أى هواية. } \\
& \text { نظرتها للمستقبل: سوداوية ومظلمة. }
\end{aligned}
$$

المخاوف: الحالة تخاف من المستقبل جدًا لأنه مبهم بالنسبة لها وتخاف على أبناءها وتخاف من الله بدرجة كبيرة جدًا. 


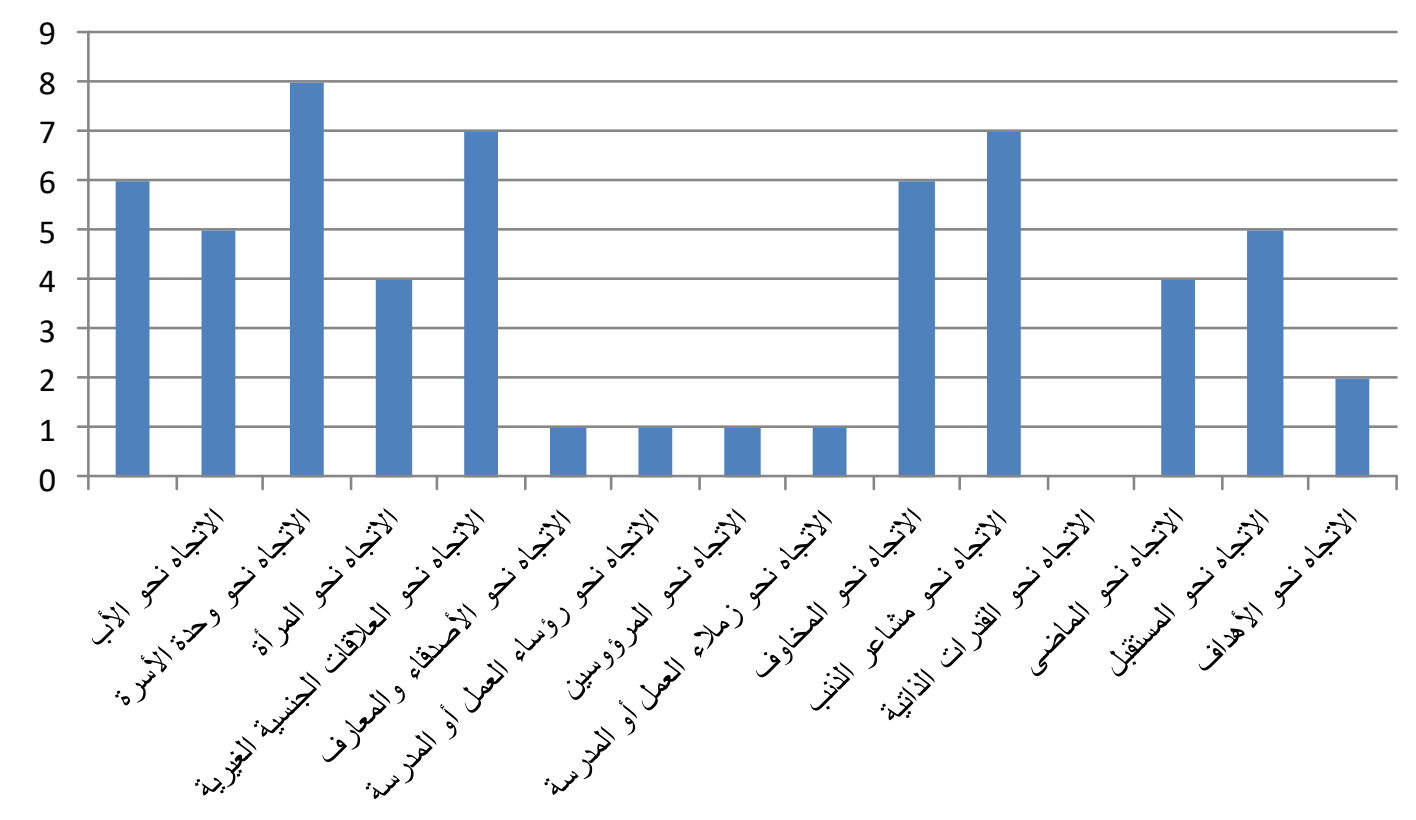

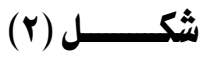

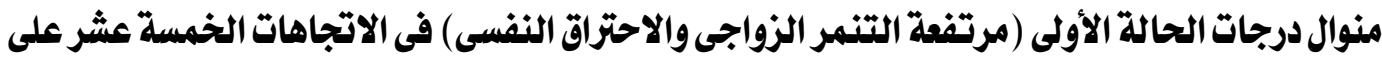
اختبارساكس لتكملة الجمل تفسيرات استجابات الحالة الأولى على اختبار ساكس لتكملة الجمل: 1- الاتجاه نهو الأم:

تثير استجابة الحالة إلى أنه يوجد اضطراب فى الاتجاه نحو الأم وظهر ذلك فى الكى

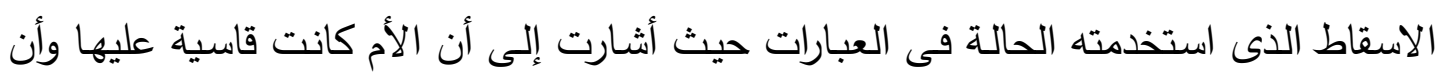

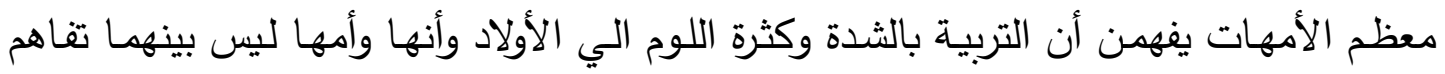

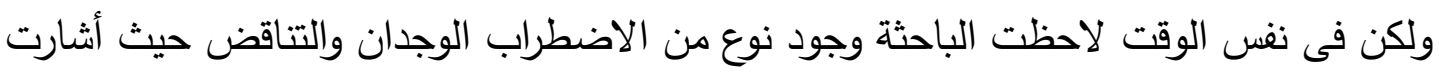

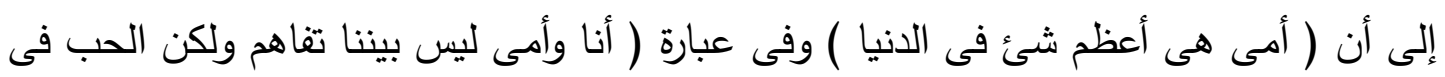
قلوبنا لبعض) وهذا يثير الي تناقض وجداني تجاه الام.

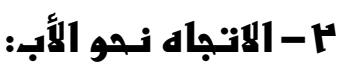

تشير استجابة الحالة إلى وجود اضطراب فى الاتجاه نحو الأب فتذكر الحالة أن والدها قليلاً ما أثعرها بالحنان والحب والعطف وكانت تتمنى أن لو قام بمجرد نصيحة لزوجها بإتقاء الله

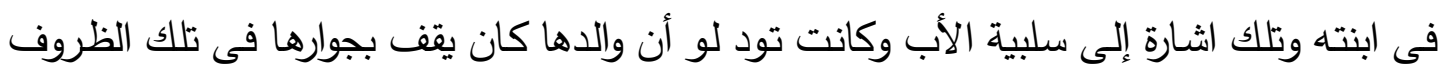

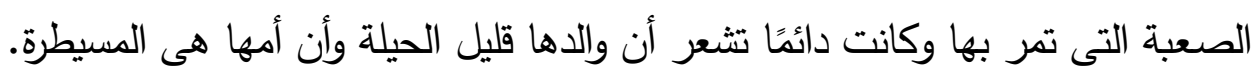




\section{"ما - الاتجاه نهو وصدة الأسرة:}

تثير استجابة الحالـة إلى وجود اضطراب تجاه وحدة الأسرة حيث أن أسرتها غير

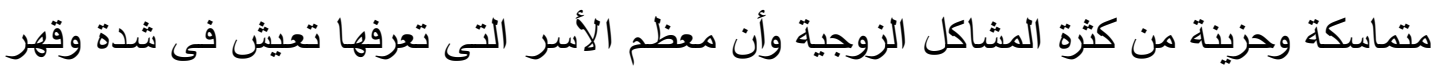

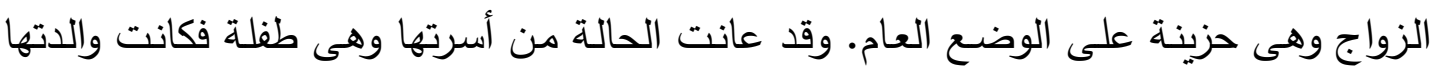

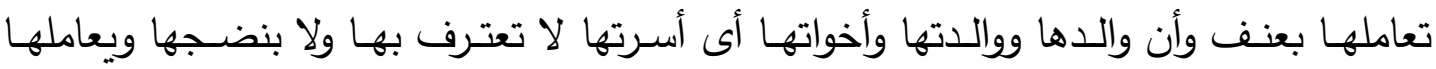
الجميع وكأنها صغيرة وليس لها رأى فى حياتها.

\section{ع-1الاتجاه نهو المرأة:}

تشير استجابة الحالة إلى وجود اضطراب فى الاتجاه نحو المرأة فهى ترى أن معظم

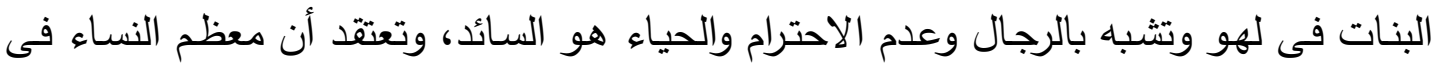
ظلم وقهر ووحدة وربما ذلك يعكس الوضع الذى تعيش فيه وكذلك المحيط بها فى الاطار الذى دالى تحيا فيه وربما ذلك هو سبب الاتجاه السلبى بالإضافة إلى المعاملة القاسية والتتمر عليها وعلى لونى شكلها وأنها غير جميلة ولذلك فآخر ما تحبه فى النساء هى أمها وخالتها، أما عن فكرتها عن الناه المرأة الكاملة فهى التى تتحلى بالصبر والحب والتى تعطى بلا حدود.

\section{0-1الاتجاه نهو العلاقات الجنسية الغيرية:}

تشـير استجابة الحالـة إلى وجود اضطراب قوى وشديد فـى الاتجـاه نحو العلاقـات الجنسية الغيرية فتصف حياتها الجنسية بأنها لا شئ ولا تريدها على الاطلاق وتتمنى أن يكون لها علاقات جنسية وربما يرجع ذلك الكره الثديد إلى الأسلوب المبتذل الأنانى الذى يطبع عليه الإنافيه

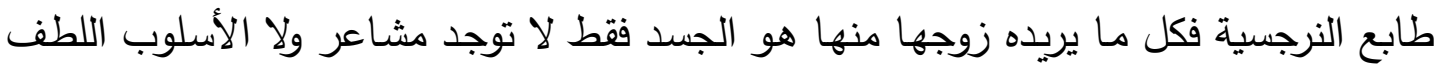
ومراعاة الآخر وعندما ينتهى من رغباته يتركها كم مهمل ويعتقها وهذا سبب من الأسباب التى لتى لابل جعلت شعورها نحو الحياة الزوجية سلبى ووصفتها بالمشاكل وعدم الراحة وعندما تشاهد رجل وامرأة تتمنى أن تكون مثلهم وتتمنى سعادتهم.

\section{1-1الاتجاه نحو الأصدقاء والمعارف:}

تثير استجابة الحالة إلى عدم وجود اضطراب فى الاتجاه نحو الأصدقاء والمعارف فهى عندما تكون بين أصدقاءها تثعر بالراحة والحب وهم الذين يقدمون لها الدعم والمساندة، وأن الناس الذين تحبهم أكثر من غيرهم هم الذين يحبونها فى الله بعيدًا عن الدصالح والأهواء بلهاء

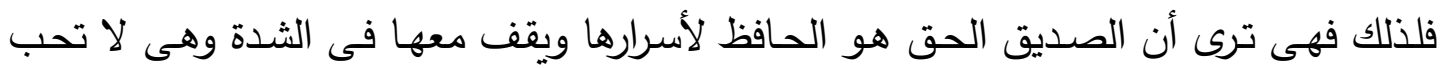


الناس الذين يكذبون وينافقون ويتكبرون وأثارت إلى أن علاقتها بأصدقاء علاقة حميمية قائمسة على الاحترام والتقدير والمشاعر الراقية والحب فى الله وهو ما تفتقده فى حياتها الزوجية.

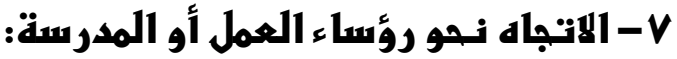

تشير استجابة الحالة إلى عدم وجود اضطراب فى الاتجاه نحو رؤساء العمل والمدرسة فذكرت الحالة أن الناس الأعلى منها تتمنى لهم السعادة وتتمنى لهم الخير والبركة وهذا يدل إلى البه على التصالح مع الذات، بالنسبة للمدرسين كانت تحترمهم وتخاف من بعضهم.

ג-1الاتجاه نـور المرؤوسبين:

تشير استجابة الحالة إلى عدم وجود اضطراب فى الاتجاه نحو المرؤوسين فهى عند اصـدار الأوامـر للغير تفضـل النصـح والأسـلوب اللين الذَى يتقبله، وذكرت أن النـاس الذذين يعملون من أجلى هم الأقرب إلى قلبى ومن خلال استجابتها على عبارة لو أننى كنتت المسؤل

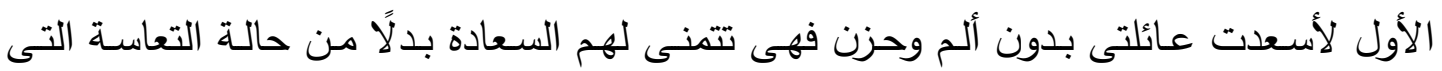

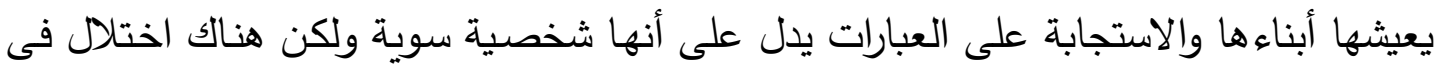
حياتها الزوجية.

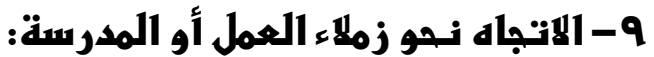

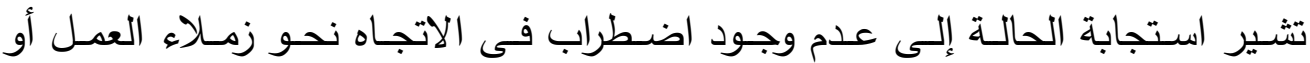
المدرسة فهى تحب أن تشتغل مع الناس الذين عندهم أمانة وخوف من الله وهى حالياً لا تشتغل ولكن تتمنى وجود شغل وذكرت أنها أكثر انسجامًا مع بناتها وأخوها الأكبر وعائلته.

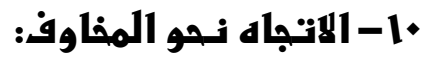

تشير استجابة الحالة إلى وجود اضطراب فى الاتجاه نحو المخاوف فهى تخاف من الظلم والتكبر وتخاف من الفتن والنميمة وبودها أن تتخلص من الخوف من ظلم الحياة أو الثئ الخفى الذى لا يعلمه إلا الله إلا أنها فى قلق وخوف من المستقبل المجهول بسبب كثرة المشاكل

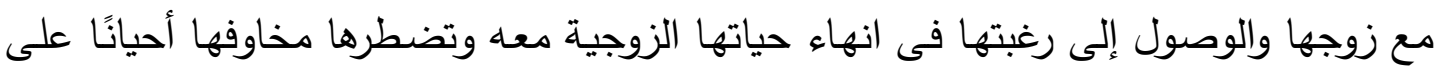
بناتها التراجع عن فكرة الخعع من زوجها. 11-1لاتجاه نهو مشنا عر الذنب:

تشير استجابة الحالة إلى وجود اضطراب شديد فى الاتجاه نحو مشاعر الذنب حيث أسقطت ما بداخلها فى عبارة كانت أكبر غلطة ارتكبتها فى حياتى هى زواجى من زوجى وهذا 
يدل على مدى البؤس الذى هى فيه الآن، وأنها على استعداد لعمل أى شئ ينسيها ذلك الوقت

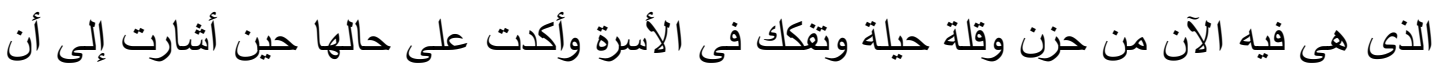

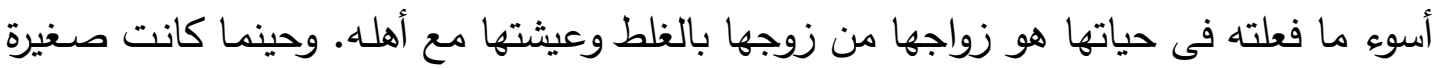

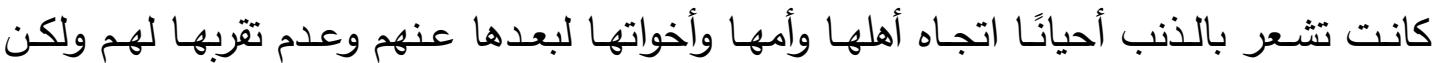
أسلوبهم السئ كان هو السبب.

\section{rا-الاتجاه نهو القدرات الذاتية:}

تشير استجابة الحالة إلى عدم وجود اضطراب فى الاتجاه نحو القدرات الذاتية فدائمًا

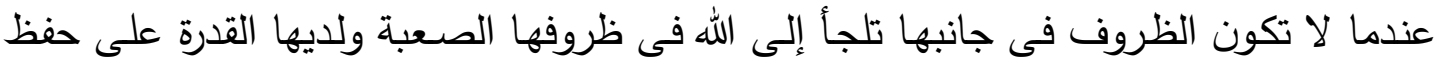
الأسرار وفعل الخير وأكبر نقطة ضعف عندها هى أولادها فهم أهم شئ فى حياتها، عندما يكون الحظ ضدها فتثكر الله دائمًا وتطلب منه الخير والحالة علاقتها جيدة مع الله ومتدينة ولكن ما تفتقده التعامل السليم مع نمط شخصية زوجها وتفتقر إلى الذكاء العاطفى.

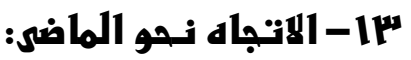

تشير استجابة الحالة إلى وجود اضطراب فى الاتجاه نحو الماضسى فهى لم تعش طفولتها مثل بقية الأطفال ورغم ذلك فإنها تتمنى أن تظل صغيرة ولا تكبر بسبب ما هى فيه التها الآن من مشاكل وحياة مفككة، وعندما كانت طفلة كانت تتمنى الزوج الصالح.

\section{1ع-1الاتجاه نسو المستنقبل:}

تثير استجابة الحالة إلى وجود اضطراب فى الاتجاه نحو المستقبل فيبدو لها المستقبل وكأنه ظلمة صعب فيها النور، وتفكر دائيًا فى الأيام القادمة كيف ستكون، وأنها حزينة لأنها

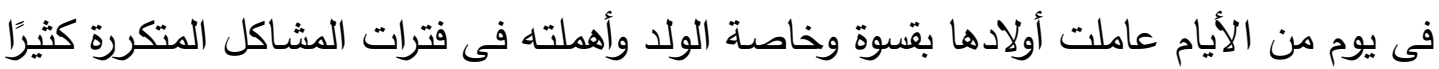
مع والدها بسبب سيطرة والده عليه ومجاولة اكتسابه فى صفه وعندما يتقدم بها السن فإنها سوف تطلب من الله الرضا والرحمة ومسامحة الذين حولها.

10- الاتجاه نبو الأهداف:

تشير استجابة الحالة إلى عدم وجود اضطراب فى الاتجاه نحو الأهداف فهى تبغى

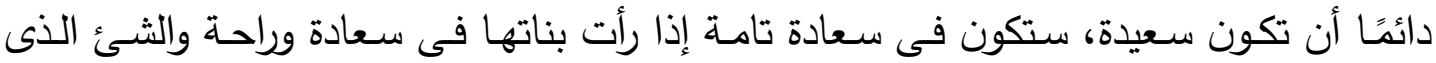

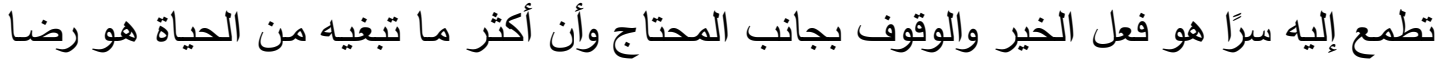
الله عنها وابتغاء وجها الكريم وحب الناس لها. 
في ضوء استجابات الحالة علي اختبار " ساكس " فان أكثر المجالات اضطرابًا لاى الحالة الاتجاه نحو وحدة الأسرة، والاتجاه نحو العلاقات الجنسية الغيرية، والاتجاه نحو مشاعر التان الذنب، يليهج الاتجاه نحو الأم، الاتجاه نحو الدخاوف، يليهم الاتجاه نحو الأب، يليهم الاتجاه

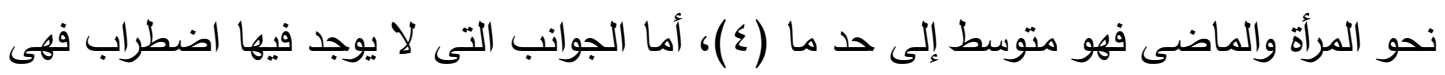

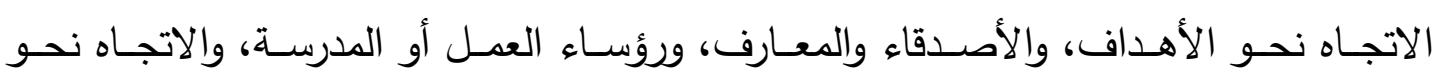

$$
\text { المرؤوسين وزملاء العمل وكذلك الاتجاه نحو القدرات الذاتية. }
$$

والحالة تعانى من حالة حزن وكآبة وتتمر مستمر من قبل الزوج مما جعلها تنكر فى ولى ولى

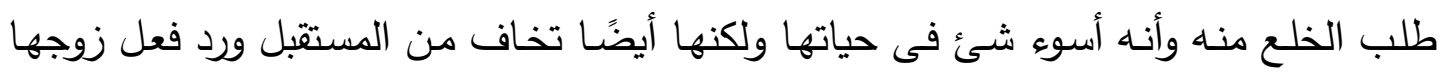
وكذلك كيف تصرف على نفسها فهو العائل المادى وهى ربة منزل لا تعمل والحالة على درجة إيمانية جيدة ولكن نمط شخصيتها من القوالب الجامدة التى لا تحسن التصرف أيضًا وتفتقر إلى لى لهـ

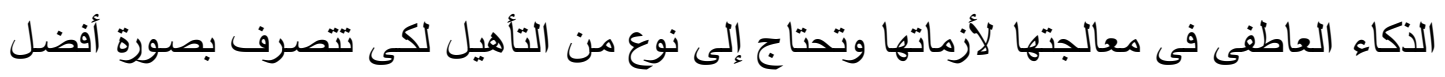

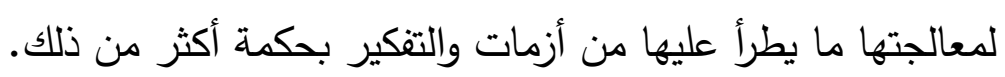

\section{الحالة الثانية}

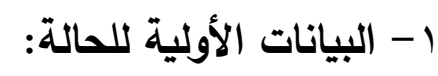

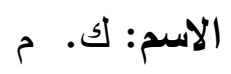

العمر الزمنى: بr سنة

عدد سنوات الزواج: 9 سنوات

المهنة: مدرس مساعد بإحدى الكليات

$$
\text { عدد الأبناء : ب مدرب }
$$

$$
\text { عمر الزوج: یب سنة }
$$

المهنة: مدرس بإحدى الدول العربية

المستوى الاجتماعى: مرتفع

المستوى الاقتصادى: مرتفع 
r- ملخص الحالة من خلال استمارة المقابلة الثخصية والملاحظة الكلينيكية المباشرة وغير المباشرة: تركيبة الأسرة: تتكون الأسرة من خمس أفراد الأب، الأم، ثلاث أبناء، الكبرى 1 سنوات، أثنان ذكور توأم. الحالة السكنية: كانت تعيش الأسرة فى سكن متوسط ثم انتقلت إلى منزل أفضل من حيث البناء وكذلك المنطقة السكنية أرقى. تاريخها الأسرى: الأسرة التى تتحدر منها الحالة أسرة متوسطة الحالة عانت من الكثير من الأزمـات والمشـاكل الماديـة والثخصية بسبب اختلاف شخصية الوالدين فقد كان الأب قليل الخبرة ولكن طيب القلب والأم شديدة ومسيطرة ولكنها حكيمة حافظت على الأبناء فى وجود

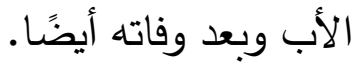
الحالـة الصـحية: الحالـة عانت كثيرًا من أزمات صحية ونفسية والجانب النفسى أكثر وخاصة بعد زواجها فقد كانت ترسم صورة لحياتها ولكنها اتصدمت بواقع أصعب. علاقاتها الاجتماعية: تتميز الحالة بأنها شخصية اجتماعية محبوبة من الجميع وعلاتهاتهاتها ولصاتها طيبة مع جميع المحيطين ولديها قبول اجتماعى.

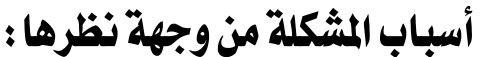

• الغل والحقد من أهل الزوج الثديد وخاصة الغيرة المرضية من والدة زوجها رغم أنها لم تقدم لهم غير كل طيب.

اختلاف الثخصية والطباع بين الزوجين ووجود بعض الاحساس بالنقص من جانب الزوج بسبب أنه مدرس وهى أستاذة جامعية.

• عدم تقدير الزوج للدور الكبير الذى تقوم بـه فهو أغلب الوقت مسافر وهى تحمل مسئولية الأسرة كاملة وعندما ينزل من السفر تكون فترة تعيسة مليئة بالمشاكل. كيفية مواجهة الأزمات الزواجية: استخدمت الحالة الكثير من الأساليب الايجابية فى حدود علمها واستخدمت الرفق واللين والصبر والحكمة ولكن هذا لم يحل لها أزماتها فى مقابل نرجسية الزوج والعيش فى بيت العيلة بمعنى أصح إلى أن وصلت الحالة إلى درجة مرتفعة من الاحتراق النفسى وقررت الأنفصال. 
نمط حياتها وكيف تدير وقتها: شخصية منظمة وحكيمة فرغم مسئولية العمل والمنزل

والأطفال لكنها كانت على درجة عالية من التوازن بين جميع الجوانب منظمة من ناحية إدارة الوقت والمنزل أيضًا وناجحة فى عملها. الهوايات: تحب القراءة وبعض الأعمال اليدوية.

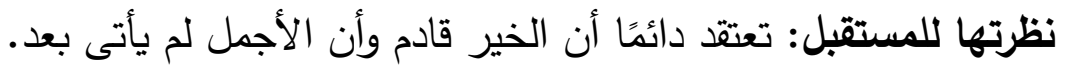
المخاوف: تخاف على أبنائها ولكن يقينها بالله عالى جدًا.

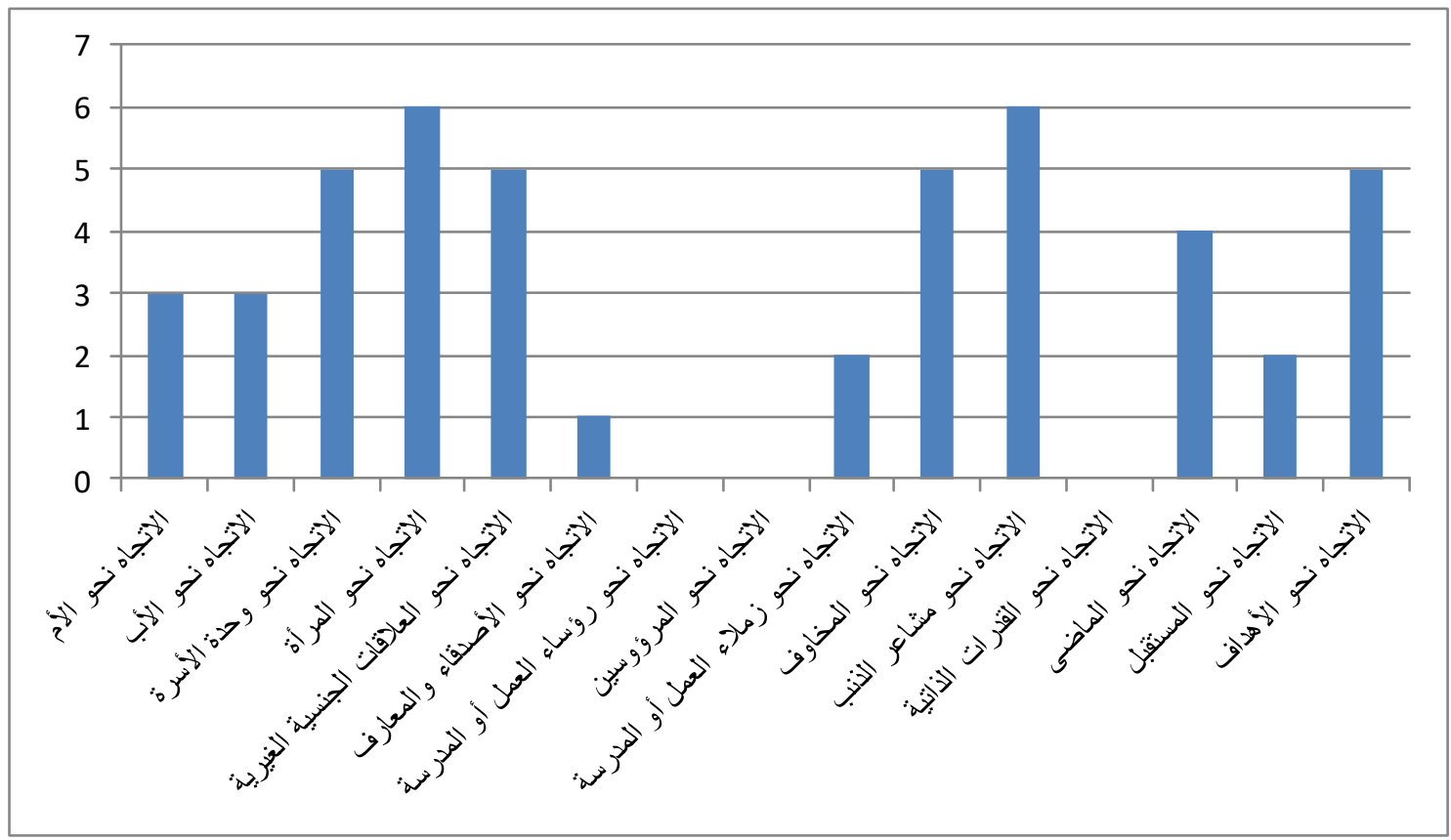

شكل (r)

منوال درجات الحالة الثانية (مرتفعة التنمر الزواجى والاحتراق النفسى) في الأتجاهات الخمسة عشر على احتبارساكس لتكملة الجمل

نتائج الدراسة الكلينكية على الحالة الثانية: 1- الاتجباه نحو الأم:

تشير استجابة الحالة إلى عدم وجود اضطراب فى الاتجاه نحو الأم حيث تقدر الحالة

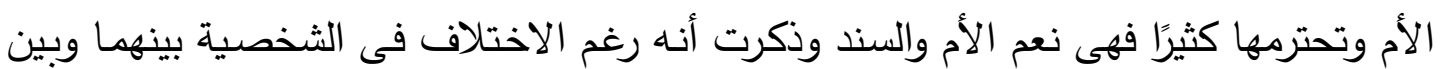
الأم إلا أنها تصف أمها بالعقلانية والحكمة وتظن أن معظم الأمهات يجب أن يقتربوا من بناتهم وهى تحب أمها كثرًا ولكن كانت قاسية عليها فى بعض الأمور وكانت تقلل من شأنها. 
تثير استجابة الحالة إلى عدم وجود اضطراب فى الاتجاه نحو الأب فهى تصف والدها

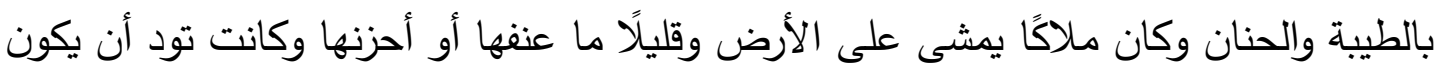
والدها أثد من ذلك فى شخصيته حتى لا يتجرأ عليه أحد لأن طيبته أفقدته كثيرًا من حقوقه.

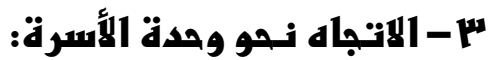

تثير استجابة الحالة إلى وجود اضطراب فى الاتجاه نحو وحدة الأسرة فأسرتها إذا قورنت بمعظم الأسر الأخرى فهى أسرة حزينة أغلب الوقت وحياتهم غير متوازنة ويوجد الكثير من المشاكل بين الأب والأم والاختلاف أما عن معاملة أسرتها لها فتعاملها وكأنها قليلة الخبرة ورأيها لا يأخذ بها وكان هذا يحزنها كثيرًا لأنها بالفعل عكس ذلك ومعظم الأسر التى تعرفها كانت تعيش فى استقرار أكثر منهم وعندما كانت طفلة كان والدها يدللها كثيرًا.

\section{ع-1الاتجاه نهو المرأة:}

تثير استجابة الحالة إلى وجود اضطراب فى الاتجاه نحو المرأة فهى ترى أن المرأة الكاملة هى المرأة المتدينة العاقلة الذكية التى تدير الأمور فى الاتجاه الصحيح ولا تستسلم أبدًا ولكن نادرًا ما يقدر الأزواج ذلك وتظن أن معظم البنات سطحية وعقولهم فارغة وبعدوا كثيرًا عن الصواب ومعظم النساء فى ظلم وعدم تقدير من الرجال وهذا يعكس حالتها واسقطت ما بداخلها فى تلك العبارة وآخر ما تحبه فى النساء هو المكر والخديعة ويوضـح أيضًا حالها فمن خلال المقابلة معها تبين أنها تعرضت لذلك كثيرًا من أهل زوجها وخاصة والدته لقلة خبرتها فى الحياة ولأنها لم تتعلم شيئاً عن ذلك المكر فى أسرتها. تئها.

\section{ه-1الاتجاه نسو العلاقات الجنسية الغيرية:}

تثير استجابة الحالة إلى وجود اضطراب فى الاتجاه نحو العلاقات الجنسية الغيريـة

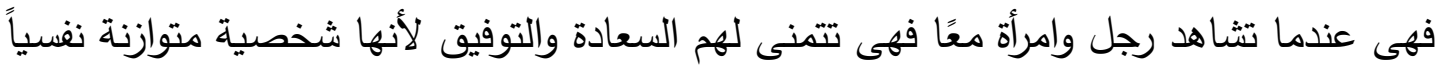

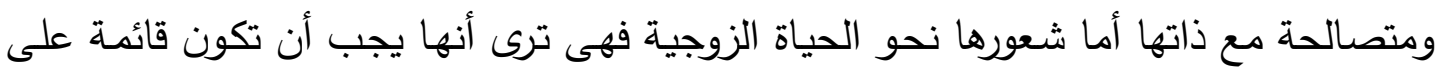
المودة والرحمة وتقدير كل طرف للآخر ومراعاة مشاعره ولكنها للأسف لم ترى ذلك فى حياتها وتعيش فى تعاسة وهى لا تتمنى أى علاقة جنسية إلا فى اطار شرعى سليم، حياتها الجنسية مضطربة جدًا. 


\section{1-1لاتنجاه نهو الأصدقاء والمعارف:}

تثير استجابة الحالة إلى عدم وجود اضطراب فى الاتجاه نحو الأصدقاء والمعارف فهى ترى أن الصديق الحق هو الذى يفهم صديقه من نظرته دون أن يتحدث ويقدر ظروفه الذه

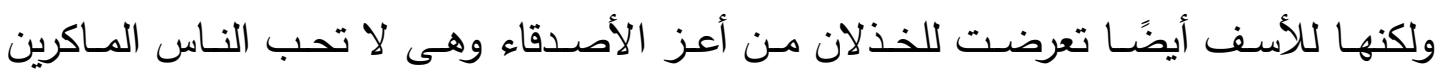
المنافقين أما الذين تحبهم أكثر من غيرهم الثخصيات الواضحة التى لا تتلون، عندما تكون بين

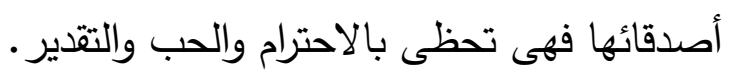

\section{Vالاتجاه نهو رؤساء العمل أو المدرسة:}

تشير استجابة الحالة إلى عدم وجود اضطراب نحو الو رؤساء العداء العمل أو المدرسة فالناس

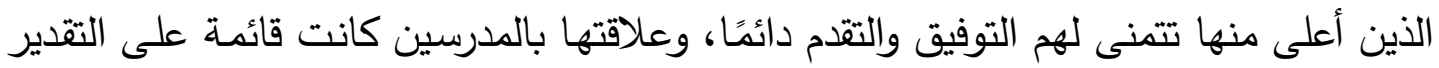

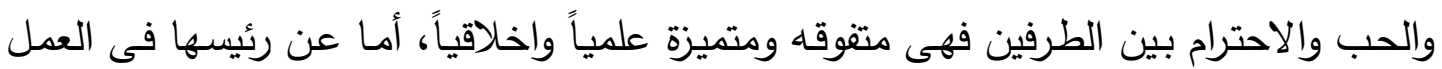
فهى تحترم من يحترمها، أما الناس الذين تعدهم أعلى منها المتميزين أخلاقياً فقط.

\section{1-1الاتجاه نهو المرؤوسين:}

تثير استجابة الحالة إلى عدم وجود اضطراب فى الاتجاه نحو المرؤوسين فلو أنها

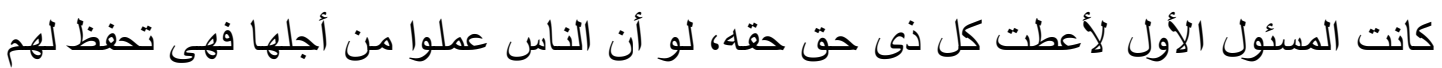

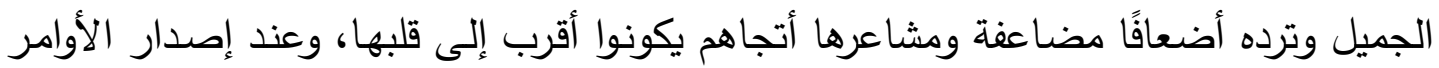
للغير تتعامل بلطف وتقدر ظروف الجميع.

\section{9-1لاتنجاه نيو زملاء العمل أو المدر سة:}

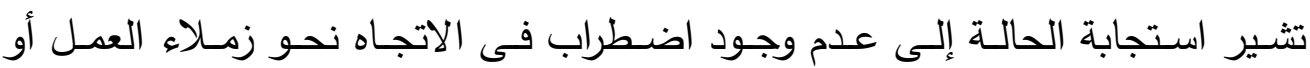

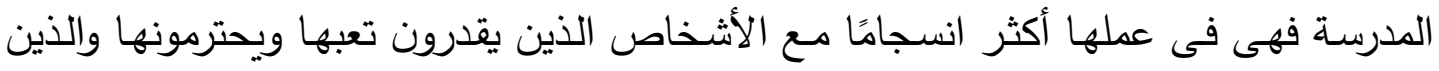

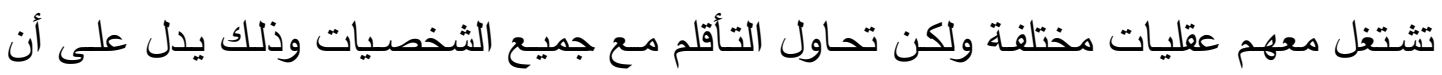

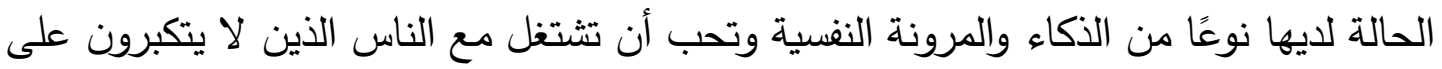
غيرهم ويعاملون الناس باللطف، الناس الذين تثتغل معهم فمنهم الحسن العطاء ومنهم غير ذلك وهى فى الغالب تتجنب السئ.

\section{•1-1الاتجاه نيو المخاوف:}

تثير استجابة الحالة إلى وجود اضطراب فى الاتجاه نحو الهخاوف فهى تخاف من

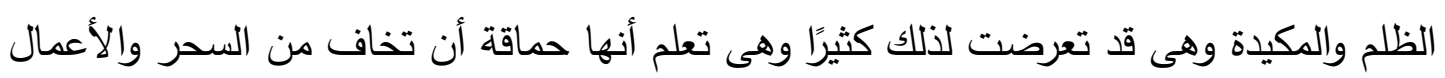


ولكنها من كثرة المشاكل التى عاشتها مع زوجها يتقنت أن هناك شئ غير طبيعى من قبل أهل

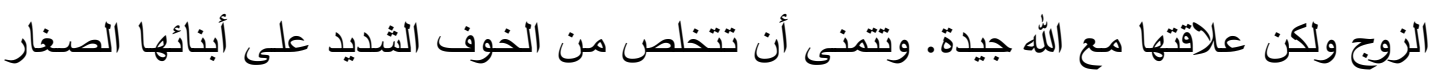

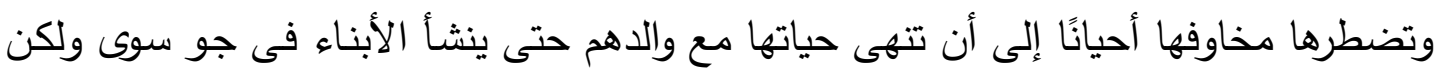
تخاف على شكلهم الاجتماعى حين يكبروا. 11-11- الاتجاه نهو مشا عر الذنب:

تشير استجابة الحالة إلى وجود اضطراب شديد فى الاتجاه نحو مشاعر الذنب فهى

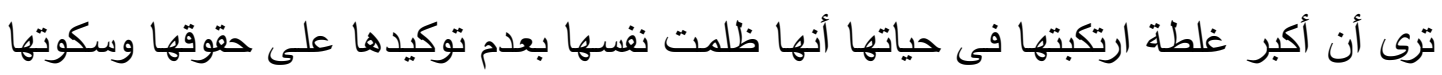

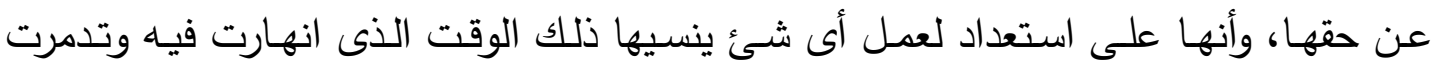

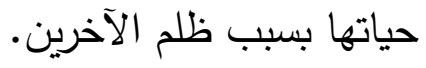

\section{rا-1الاتجاه نهو القدرات الذاتية:}

تثير استجابة الحالة إلى عدم وجود اضطراب فى الاتجاه نحو القدرات الذاتية فعندما لا تكون الظروف فى جانبها تصبر وتحاول التكيف لحين الوقت المناسب وتعتقد دائمًا أن لديها القدرة على النجاح والتميز وأكبر نقطة ضعف عندها هى أبنائها، عندما يكون الحظ ضدها

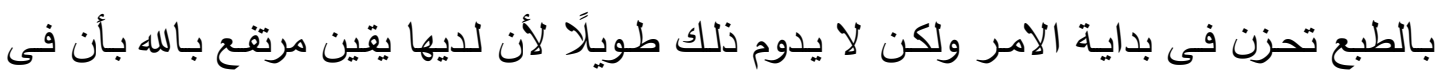
المحن تأتى المنح.

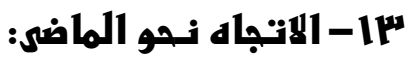

تثير استجابة الحالة إلى وجود اضطراب فى الاتجاه نحو الماضى فعندما كانت طفلة لم تستمتع بطفولتها ولم تعيشها مثل بقية الأطفال لم تخرج كثيرًا بل كانت هناك قئه الكيود من الأسرة وخوف شديد عليها وتتمنى لو عادت صغيرة سوف تستمتع بقدر الامكان وتثير الاستجابة إلى

$$
\text { وجود نوع من الحرمان. }
$$

1E - 11 الاتباه نسو المستنقبل:

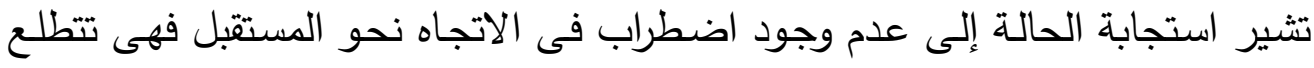
دائمًا إلى مستقبل أفضل من الوضع الذى هي على عليه الآن ويبدو لها المستقبل رغم أنه ينتبابها

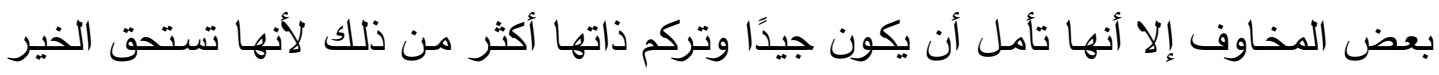

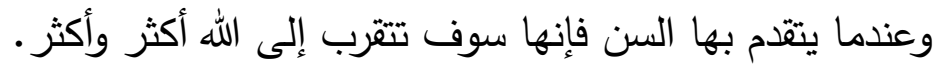




\section{0-10اتجباه نسو الأهداف:}

تشير استجابة الحالة إلى وجود اضطراب فى الاتجاه نحو الأهداف فلقد كانت تبغى دائمًا أن تعيش حياة زوجية سعيدة ولكن للأسف لم تجد ذلك وستكون فى سعادة تامة إذا انتهت مشاكلها

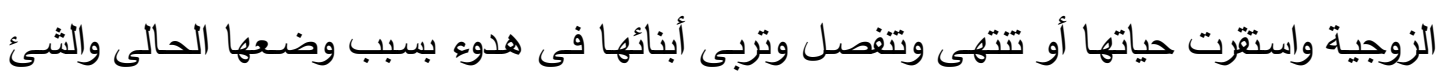

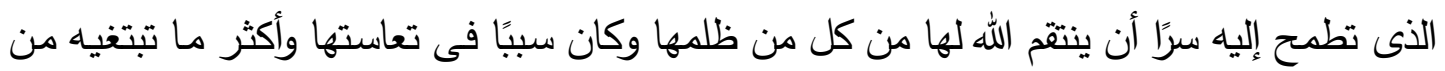
الحياة هو رضا الله وعفوه عنها والتوفيق فى حياتها وتصل بأبنائها إلى بر الأمان.

ترى الباحثة أن أكثر المجالات اضطرابًا لاى الحالة هى الاتجاه نحو مشاعر الذنب،

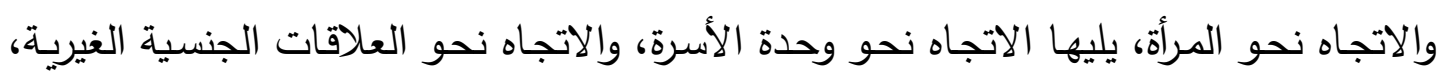
والاتجاه نحو المخـاوف، والاتجاه نحو الأهداف، ويليها الاتجاه نحو الماضى، والحالة على درجة عالية من العلم والمرونة ولكن لديها نقص فى الثقة بالنفس والتوكيدية وهذا عامل من عوامل التتمر الذى تعرضت له بالإضافة إلى نرجسية الزوج ومما وصل بها إلى حالة الاحتراق

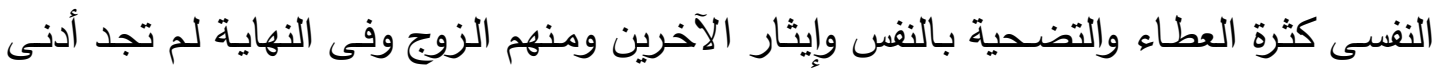
تقدير مما جعلها تفكر فى انهاء حياتها الزوجية بسبب الاكتئاب النفسى الذى وصلت لله بسبب

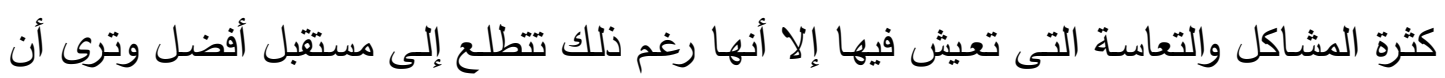
الخير قادم وأن الله معاها.

\section{تعقيب عاه على الحالتين : - ت}

من خـلال الدراسـة الكلينكية حاولت الباحثة فهم ديناميات المرأة التى تتعرض للتتمر والوقوف على أوجه التثابه والاختلاف بين الحالتين أما عن أوجه التثابه فكانت كالآتى: الحالتين على درجة عالية من الايمان والتدين.

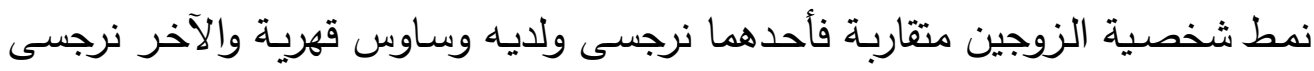
وعلى درجة عالية من العصبية لأبسط الأمور .

$$
\text { • الخوف الثديد على الأبناء. }
$$

" ضعف الثقة بالنفس وضعف التوكيدية لدى الحالتين.

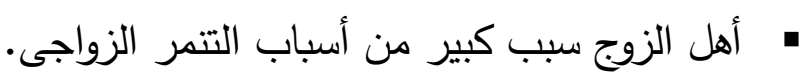




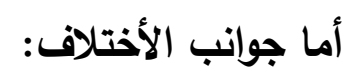

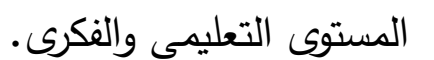

نمط الثخصية مختلف فالحالة الأولى شخصيتها بها جمود فكرى أمسا الحالة الثانية

$$
\text { لايها نوعًا من المرونة. }
$$

طريقة مواجهة الأزمات مختلفة تمامًا فالحالة الأولى سلبية بدرجة كبيرة أما الحالة الثانية

$$
\text { فاستخدمت أكثر من طريقة. }
$$

أما عن أهم النتائج التى توصلت إليها الدراسة الكلينكية فهى كالتالى:

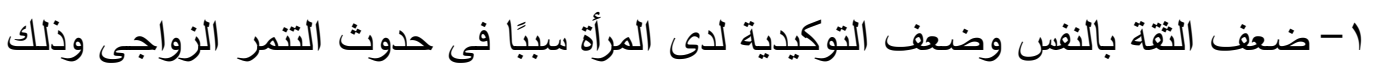

$$
\text { يتقق مع العديد من الدراسات السابقة. }
$$

r- الثخصية النرجسية للزوج تعتبر منبئ بالتتمر الزواجى.

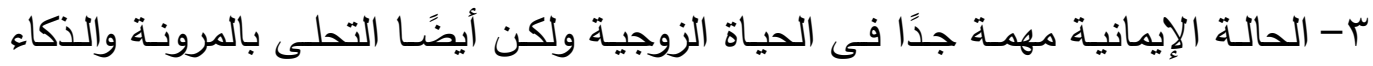
الوجدانى أساس لمواجهة الأزمات والصراعات التى كادت أن تنهى الحياة الزواجية.

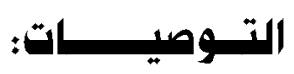

ضرورة عمل برامج وقائية للمقبلين على الزواج والمتزوجين حديثًا لكيفية الوقاية من الآثار السلبية للاحتراق النفسى وكذلك مواجهة التتمر لاى أحد الزوجين. دراسة التمكين النفسى للمرأة التى تتعرض للتنمر باستخدام الذكاء الوجدانى.

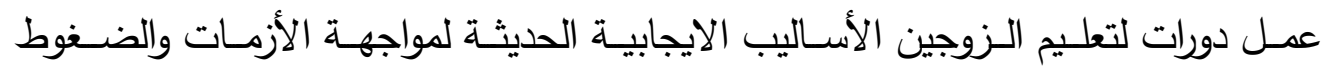
الزواجية وكنلك تعليم المتتمرين من الرجال طرق التعبير عن الذات بأسلوب غير تعسفى.

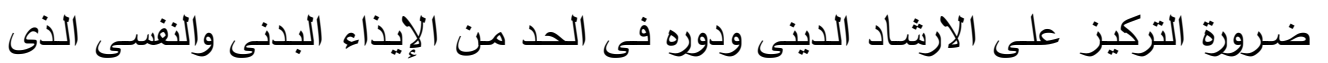
تتعرض له المرأة.

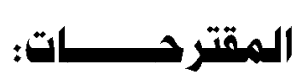

1 - فعالية برنامج إرشادى وقائى للحد من مشكلة التتمر الزواجى لاى المتزوجين حديثًا. r- فعالية العلاج الأنثوى فى مساعدة المتتمرين من الرجال فى التعبير عن الذات بطرق

$$
\text { غير تعسفية (التى لا تقوم على الإساءة والإيذاء). }
$$

r- فعالية العلاج المرتكز على الحل للحد من الانهاك الانفعالى لدى عينة من الزوجاءت ولإدات المعرضات للتتمر . 


\section{المسراجـ}

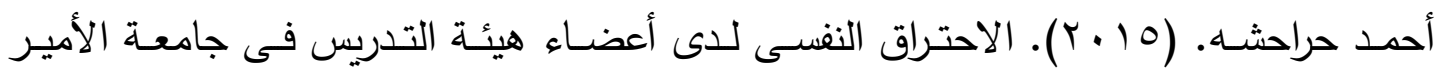
سـلطان بـن عبـد العزيـز فـى ضـوء بعض المتغيـرات. مجلــة كليـة التربيـة، جامعــة

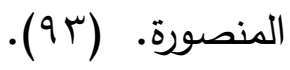

أمل العواودة. (ع . . †). ظاهرة العنف ضد المرأة العاملة فى الأردن. مجلة الحوار المتددن. تم http://www.ahewar.org الاسترداد من

جواد دويك. ( . . . ( ). العنف المدرسى. بيروت : مكتبة لبنان . حسن مصطفى. (r . . r). منهج البحث الاكلينكى: أسسـه وتطبيقاتـه. القاهرة : مكتبـة زهراء الثرق م.

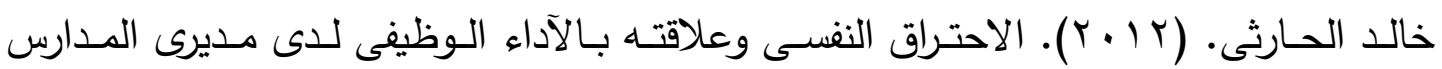
الثانوية بمحافظة الطائف. مجلة كلية التربية، جامعة عين شمس، الجزء ب (بr). رشاد على. (1 (1 • ). العنف ضد المرأة فى المجتمع المصرى. رسالة دكتوراة، معهد الدراسات والبحوث الاحصائية، قسم الاحصاء الحيوى والسكانى، جامعة القاهرة. سعيد طه. ( • ( • ( ). العنف الجسدى وآثاره النفغسية. القاهرة : الرشاد للنشر والتوزيع. طريف شوقى. (Y ( • r). العنف الأسرى: دراسة ميد/نية على مستوى المدلكة العربية السعودية.

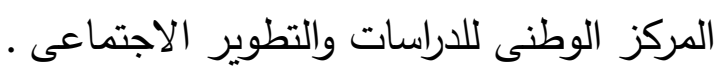

عبد الله العلاف. (9 . . r). العنف الأسرى وآثاره على الأسرة والمجتمع. تم الاسترداد من الن Al.alof@hotmail.com

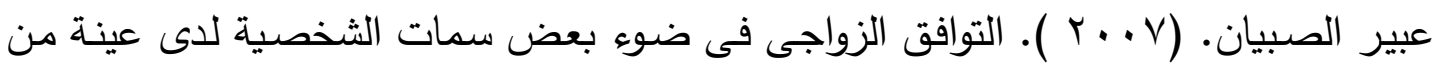
الزوجات السـوديات فى مكة المكرمـة. المؤتمر السنوى الرابع عشر ، مركز الارشـاد النفسى، جامعة عين شمس، ص ص 19900 11 100

عـزة صـديق. ( • ( • ب). الاحتـراق النفسى وعلاقتهـ بـالأدوار المنوطـة بـالمرأة. مجلـة دراسـات عربية، رابطة الإحصائيين النفسيين المصرية، 9 (ب).

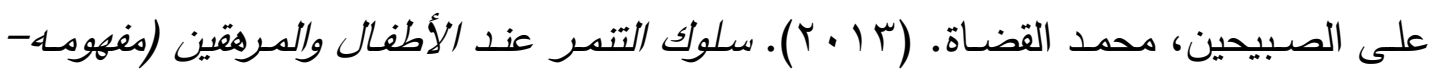
أسبابه- علاجه). الرياض: مكتبة الملك فهد الوطنية. على عسكر • ( . . . . ). ضغوط الحياة وأساليب مواجهتها . طr. الكويت: دار الكتاب الحديث. 


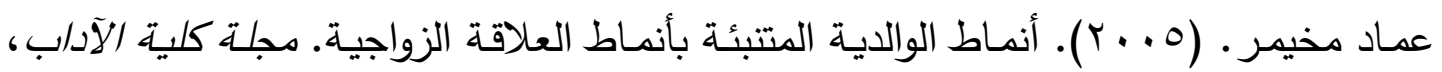

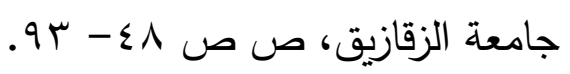

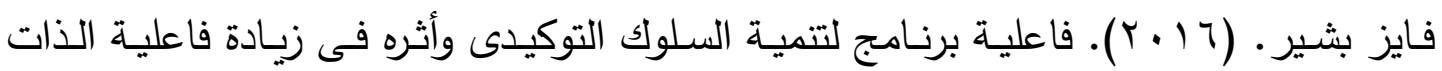

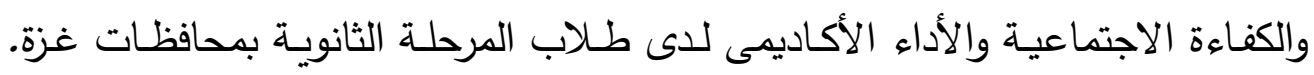

رسالة دكتوراة، معهد البحوث والدراسات العربية، جامعة القاهرة.

ليلى مرح. (9 . . r). العنف ضد المرأة فى المجتمع الليبى وعلاقته بالتخلف الاجتماعى. رسالة

ماجستير، جامعة الفاتح: ليبيا.

محمد أبو حلاوة. (r ( ب). حالة التدفق: الدفهوم، الأبعاد، والتقياس. الاصدار الثالث، شهر

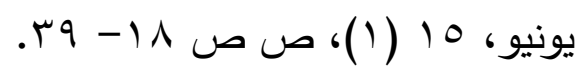

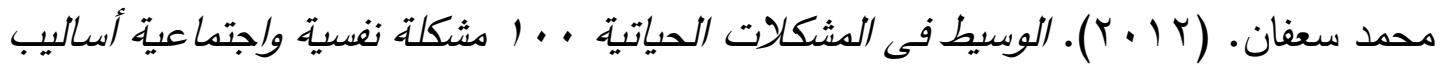

$$
\text { التثخيص، طرق العلاج. القاهرة: دار الكتاب الحديث. }
$$

محمد صديق. (9 . . r). التدفق وعلاقته ببعض العوامل النفسية لاى طلاب الجامعة. مجلة

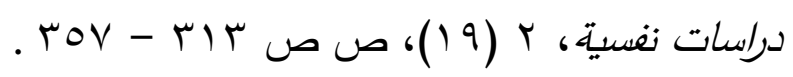

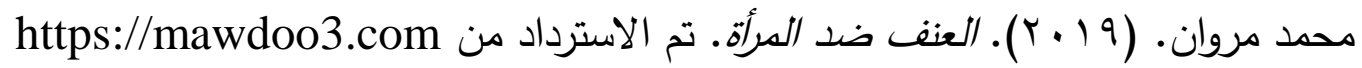

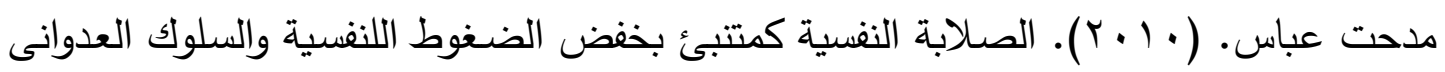

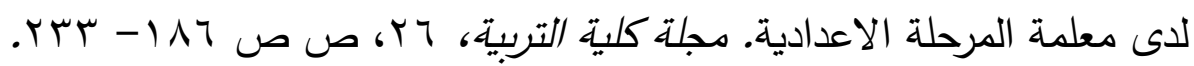

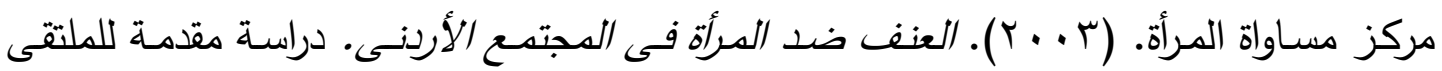

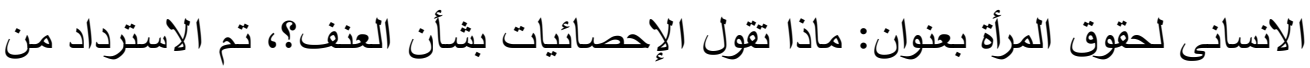
WwW.nesasasy.org/index.php

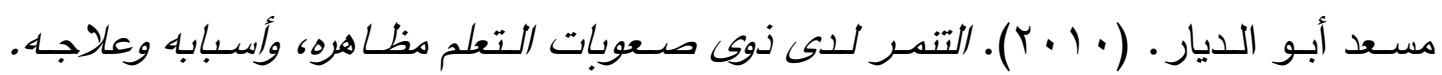
الكويت: مركز تقويم وتعليم الطفل.

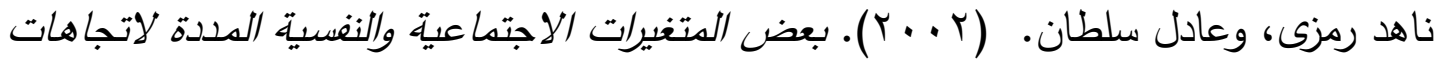

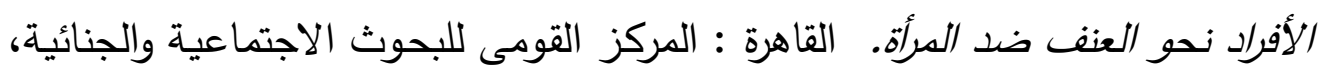

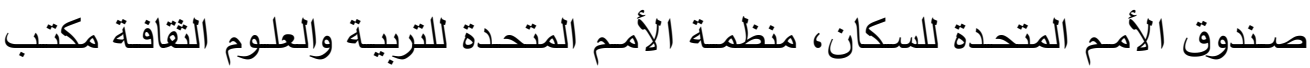
اليونسكو بالقاهرة، ندوة المرأة المصرية والتحديات المجتمعية. 
هبـة محمد. ( ( . . ب). الإسـاءة إلى المـرأة دراسـة فى سيكوديناميات العلاقـة الزوجيـة. رسالة دكتورة، كلية الآداب، جامعة الزقازيق.

هبة محمد. (ع ( • Y). الصـود النفسى كمتغير معدل للعلاقة بـين الاحتراق النفسى والرضـا

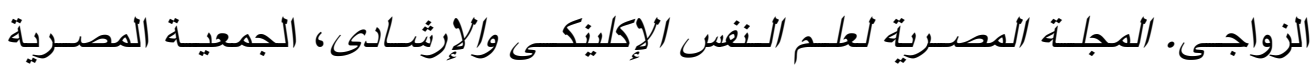

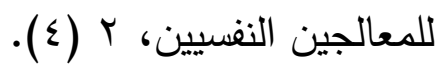

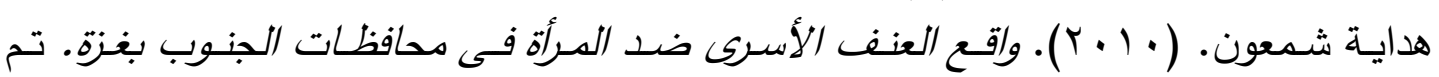
الأسترداد من WWW.Womengateway.com

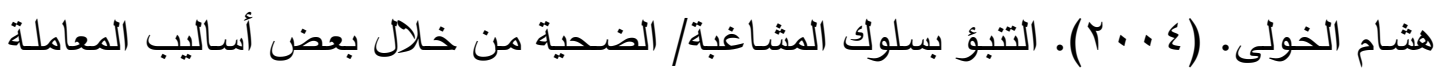

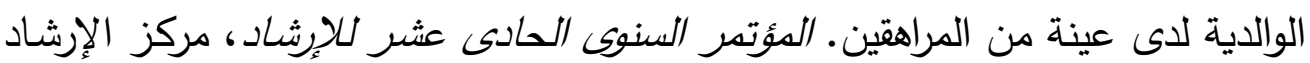

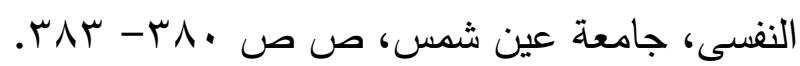

Anderson, N., Cockcroft, A., Ansari, U., Omer, K., Ansari, N., Khan, A., et al. (2010). Barriers to Disclosing and Reporting Violence Among Women in Pakistan: Findings From Anational Household. Journal of Interpersonal Violence, 25(11), 1965 -1985.

Babu, B., \& Kar, S. (2009). Domestic Violence Aganist Woman in Eastern India: a Population Based Study on Prevalence and Related Issuse BMC Public Health. 9 - 129.

Callifford, S. (2000). Early Development Influnces on the Capacity for Mutuality in Marital Relationshipe. Disseration Abstracts International, 4, 2240.

Das, M. (2014, July- December). Using Social Networking Sites (SNS): Mediating Role of Self Disclosure and Effecton Well being. Indore Mangment Journal, 6(2), 30 -38.

Dikerson, D. (2005). Cyber Bullies on Camps. Retrieved October 5, 2005, from http://www.unicef.org.violence

Diop- Sidibe, N., Campbell , J., \& Beckers. (2006, Mar). Domestic Violence aganist Woman Egyp-Wife Beating and Health Outcomes. Social Science \& Medicine, 62(5), 60 - 77.

Eisenberg, N., Sadovsky, A., Spinrad, T., Fabes, R., Losoya, S., Valiente, C., et al. (2005). The Relations of Problem Behavior Status to Children's Negative Emotionality, Effortful Control and Impulisivity: Concurrent Relations and Prediction of Change. Development Psychology, 41(1), 193 - 211. 
Gracia, E., \& Herro, J. (2010). Acceptability of Demestic Violence Against Woman in the European Union: Amultilevel Analysis. Study Submitted to University of Volencia, Volencia, Spain.

Guerra, N., Huesmann, L., \& Spindler. (2003). Community Violence Exposure, Social Cognition, on Woman in Slums, Uk Pubmed Cantral, Uk, Reseach Paper Online. Retrieved from http://ukpmc,ac.uk/abstract/MED/14552412

Hawker, D., \& Boulton , M. (2000). Twenty Years Research on Peer Victimization and Psychosocial Malad Justment: A menta-analytic Review of Cross- sectional Studies. Journal of Child Psychology and Psychiatry and Allied Disciplines (41), 441- 455.

Juvonen, J., Grahman, S., \& Shuster, M. (2003). Bullying Among Young Adolescent: The Strong, The Weak, and The Troubled Pediatrics. Retrieved October 5, 2006, from Ebsco hostmaster file data base

Kalaca, S., \& Dundar. (2010). Violence Against Women: the Perspective of a Cademic Women, Bmc Public Health, Istanbul, Retrieved from http://www.Biomedcentral.com/14712458/10/490/abstact,2010.

Macsinga, I., \& Dobrita, O. (2010). More Educated Less Irrational: Gender and Educational Differences in Perfectionism and Irrationally. Romanian Journal of Applied Psychology, 12(2), 79 - 85.

Melinda, M., \& Jeanne, S. (n.d.). Ph.D. Retrieved Junne 2019

Moran, P., Bifulco, A., Ball, C., Jacobs, C., \& Benaim, K. (2002). Exploring Pshological Abuse in Childhood: Developing an New Interview Scale, Bulletin of the Minnesinger Clinic. 66(3), 213 - 241.

Nansel, T., Overpeck, M., Pilla, R., Ruan, W., Simmons-Morton, B., \& Scheidt, P. (2001). Bullying Behaviors Among Us Youth: Prevalence and Association with Psychosocial Adjustment. Journal of the American Medical Association, 285(16), 2094 - 2100. 
Promundo and un Woman. (2017). Understanding Masculinties: Results from the International Men and Gender Equality Survery (Images)- Middle and North Africa. P.16. For Lebanon Information, See Understanding Masculinities- Resuits from the International Men and Gender Equality Survery (Images) in Lebanon, P.77.

Ravneet, K., \& Suneela, G. (2008, April ). Addressing Domestic Violence Aganist Woman: An Unfinished Agenda. Indian Community Med, 33(2), 73 - 76.

Sieger, K., Rojas-Vilches, A., Mckinney, C., \& Renk, K. (2004). The effect and Treatment of Community Violence in Woman and Adolescents. Study Submmitted to The university of Central Florida, USA.

Simmons, C., Lehmann, P., \& Dia, D. (2010, Aug). Parenting and Woman Arrested for Intimate Partner Violence. Journal of Interpersonal Violence, 25(8), 1429 - 1448.

Stober, J., \& Otto, K. (2006). Positive Conceptions of Perfectionism: Approaches, Evidence, Challenges. Personality and Social Psychology Review, 10(4), 295 - 319.

Susanna, M., Helmi , L., Helina, H., Pirkko, R., Hannu, S., \& Kasia, R. (2011). Exposure to Demestic Violence and Violent Crime Associated with Bullying Behaviour Amang Underage Adolescent Psychiatric Inpatient?. Child Psychiatry Human Development, 42(4), 459- 506.

World Health Organization, D. o. (2013). Global and Regional Estimates of Violence Aganist Woman: Prevalence and Health Effects of Intimate Partner Violence and Non Partenal Sexual Violence,P.2. For Individual Country Information, See the World's Against Woman 2015, Trend and States, Chapter 6, Violence Against women,United Nations Department of Economic and Social Affairs, 2015 and un Women Globel Database on Violence Against Women. 